



\section{Letsel en schade bij vleeskuikens als gevolg van vangen, transport en handelingen aan de slachtlijn}

Marien Gerritzen, Jan Verkaik, Henny Reimert, Henk Gunnink, Theo van Hattum en Ingrid de Jong

Dit onderzoek is uitgevoerd door Wageningen Livestock Research, in opdracht van de PPS Poultry4Food (TKI-AF-12048; BO-22-04.003), en in opdracht van het Ministerie van Landbouw, Natuur en Voedselkwaliteit in het kader van het project 'Follow-up WQ Vleeskuikens (BO-43-013.02-003).

Wageningen Livestock Research

Wageningen, januari 2019

Rapport 1107 
Marien Gerritzen, Jan Verkaik, Henny Reimert, Henk Gunnink, Theo van Hattum en Ingrid de Jong, 2019. Letsel en schade bij vleeskuikens als gevolg van vangen, transport en handelingen aan de slachtlijn. Wageningen Livestock Research, rapport 1107.

Dit rapport is gratis te downloaden op https://doi.org/10.18174/467902

of op www.wur.nl/livestock-research (onder Wageningen Livestock Research publicaties).

(C) 2019 Wageningen Livestock Research

Postbus 338, 6700 AH Wageningen, T 03174839 53, E info.livestockresearch@wur.nl, www.wur.nl/livestock-research. Wageningen Livestock Research is onderdeel van Wageningen University \& Research.

Wageningen Livestock Research aanvaardt geen aansprakelijkheid voor eventuele schade voortvloeiend uit het gebruik van de resultaten van dit onderzoek of de toepassing van de adviezen.

Alle rechten voorbehouden. Niets uit deze uitgave mag worden vermenigvuldigd en/of openbaar gemaakt worden door middel van druk, fotokopie, microfilm of op welke wijze dan ook zonder voorafgaande toestemming van de uitgever of auteur.

Wageningen Livestock Research is NEN-EN-ISO 9001:2015 gecertificeerd.

Op al onze onderzoeksopdrachten zijn de Algemene Voorwaarden van de Animal Sciences Group van toepassing. Deze zijn gedeponeerd bij de Arrondissementsrechtbank Zwolle. 


\section{Inhoud}

$\begin{array}{ll}\text { Samenvatting } & \mathbf{5}\end{array}$

1

$\begin{array}{ll}\text { Aanleiding en achtergrond } & 7\end{array}$

$\begin{array}{lll}1.1 & \text { Doelstelling } & 8\end{array}$

2

$\begin{array}{ll}\text { Literatuur } & 9\end{array}$

2.1 Primair bedrijf 9

2.2 Vangen en laden $\quad 9$

$\begin{array}{ll}2.3 \text { Transport } & 10\end{array}$

$\begin{array}{ll}2.4 \text { Wachtruimte } & 10\end{array}$

3 Vaststellen vang- en laadletsel in de praktijk en de mogelijke relatie met de fitheid van het koppel

3.1 Vang- en laadletsel: materiaal en methoden 11

3.2 Proefopzet 11

3.3 Beoordelen van vang- en laadletsel $\quad 12$

3.3.1 Beoordeling aandeel letsel door transport $\quad 12$

3.3.2 Beoordeling schade na slachten en plukken 13

3.3.3 Berekening en data analyse 13

3.4 Beoordeling welzijn van het koppel $\quad 14$

$\begin{array}{ll}3.4 .1 \text { Koppels } & 14\end{array}$

3.4.2 Welzijnsmonitor vleeskuikens 14

$\begin{array}{ll}3.4 .3 \text { Berekeningen scores } & 15\end{array}$

$\begin{array}{ll}3.4 .4 \text { Berekeningen correlaties } & 15\end{array}$

$\begin{array}{llr}4 & \text { Resultaten } & 16\end{array}$

4.1 Realisatie waarnemingen 16

4.2 Vang- en laadletsel $\quad 16$

4.2.1 Reguliere versus trager groeiende kuikens 17

4.2.2 Vang- en laadletsel per vangmethode 19

4.2.3 Vang- en laadletsel per bestemming 20

4.2.4 Transportletsel $\quad 21$

$\begin{array}{lll}4.3 & \text { Slachtschade } & 24\end{array}$

4.3.1 Reguliere versus trager groeiende kuikens $\quad 24$

4.3.2 Welzijnsstatus van de subset van koppels $\quad 25$

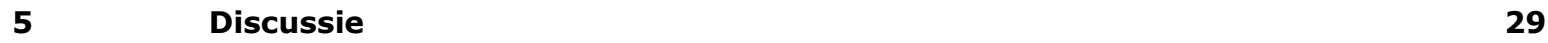

5.1 Vang- en laadletsel $\quad 29$

5.2 Transport $\quad 29$

$\begin{array}{lll}5.3 & \text { Slachtproces } & 30\end{array}$

5.4 Welzijnsmonitor vleeskuikens 30

5.5 Conclusies $\quad 31$

$\begin{array}{ll}\text { Literatuur } & 32\end{array}$

Bijlage 1 Scoreformulieren vang- en laadletsel 35

Bijlage 2 Voorbeeld rapportjes terugkoppeling koppelbeoordelingen 42

Bijlage 3 Overzicht resultaten subset koppels $\quad 45$ 
Bijlage 4 Figuren relatie voetzoollaesiescore en vang- en laadletsel

Bijlage 5 Relatie tussen score locomotie en vang- en laadletsel 50

Bijlage 6 Relatie tussen mortaliteitsscore en vang- en laadletsel 51

Bijlage 7 Relatie tussen score totaal welzijn en vang- en laadletsel 


\section{Samenvatting}

Bij het vangen, laden en transporteren van pluimvee naar de slachterij, bij het uitkratten en tijdens het slachtproces komt het voor dat een deel van de dieren letsel respectievelijk schade zoals botbreuken, bloeduitstortingen of dislocaties oploopt. Veel factoren lijken hierop van invloed te zijn. Het is van belang om niet alleen de houderij van pluimvee, maar het gehele ketenproces te blijven verbeteren om letsel en schade te voorkomen. Om dit te realiseren is een goed beeld van de grootste knelpunten in dit traject van vangen, laden, transport, uitkratten en slachtprocessen van belang. Op basis van de uitgevoerde literatuurstudie kan worden geconcludeerd dat er grote verschillen zijn in de mate van letsel en schade zoals die worden vastgesteld bij pluimvee. De oorzaken zijn divers maar de verschillende onderzoeken geven aan dat vangen en laden van pluimvee een belangrijke oorzaak is voor het optreden van letsel. Uit een aantal onderzoeken komt naar voren dat bij zwaardere dieren meer letsel wordt gezien dan bij lichtere dieren. Ook is het onbekend of er verschillen zijn in vang- en laadletsel tussen reguliere kuikens en langzamer groeiende kuikens. Daarnaast is duidelijk dat het slachtproces ook een belangrijke bijdrage aan bijvoorbeeld vleugelschade levert. Niet altijd is duidelijk of er sprake is van letsel (dus ontstaan aan het levende dier) of schade (dus ontstaan door het slachtproces) bij het al dode dier.

De doelstelling van het hier beschreven onderzoek was;

(1) In kaart brengen in welke mate letsel en/of schade optreedt bij vleeskuikens als gevolg van handelingen in het 'end-of-life'-traject, en of er mogelijke verschillen zijn tussen koppels reguliere en trager groeiende vleeskuikens;

(2) Onderzoeken of er een mogelijke relatie is tussen het welzijn van het koppel, vastgesteld met behulp van de Welfare Quality ${ }^{\circledR}$ welzijnsmonitor (Welfare Quality, 2009), en de mate waarin letsel optreedt gedurende de 'end-of-life' fase bij vleeskuikens.

Naar aanleiding van de literatuurverkenning is besloten om vang- en laadletsel vast te stellen aan 16 reguliere vleeskuikenkoppels en 16 trager groeiende vleeskuikenkoppels. Er is gekozen om het letsel vast te stellen in de wachtruimte van de slachterij direct na aankomst op de slachterij, en bij vier koppels eveneens direct na het laden op het primaire bedrijf. Uitgangspunt hierbij is dat het transport op zich geen of een kleine oorzaak zal zijn voor het ontstaan van letsel. Verkennend is bij een beperkt aantal koppels (4) zowel het vang- en laadletsel direct na vangen op het primaire bedrijf beoordeeld en direct na afloop van het transport in de wachtruimte van de slachterij nogmaals beoordeeld. Daarnaast is met behulp van de Welfare Quality ${ }^{\circledR}$ monitor (zie 3.3) bij 9 van de 16 reguliere- en 8 van de 16 trager groeiende koppels een beoordeling van het welzijn van het koppel uitgevoerd. Deze stalbeoordeling is \pm 4 dagen voor afleveren uitgevoerd. Bij de 4 koppels waar vang- en laadletsel ook direct voor transport is beoordeeld is ook een stalbeoordeling uitgevoerd.

Vier slachterijen participeerden in het onderzoek naar vang- en laadletsel, 2 met gas verdoven en 2 met elektrisch verdoven. Eén slachterij slacht zowel reguliere als trager groeiende kuikens. De andere 3 slachterijen slachten uitsluitend reguliere kuikens. Op alle 4 de slachterijen zijn in de slachtlijn, na plukken de beoordeelde kuikens nogmaals beoordeeld op bloedingen, dislocaties en breuken. Hierdoor is het mogelijk om inzicht te krijgen of er sprake is van vang- en laadletsel of dat er sprake is van slachtschade.

Bij beoordeling van de levende kuikens direct na aankomst op de slachterij blijkt dat vleugelbloedingen en vleugeldislocaties het meest voorkomende letsel zijn. Bloedingen aan de vleugel groter dan $1 \mathrm{~cm}$ worden gezien bij gemiddeld 4,5\% van de kuikens. Vleugelbloedingen treden iets vaker op bij trager groeiende kuikens (4,7\%) dan bij de reguliere kuikens (4,3\%). Vleugeldislocaties zijn na bloedingen het vaakst gescoorde letsel. Bij reguliere kuikens werd bij gemiddeld 1,5\% van de kuikens een vleugeldislocatie geconstateerd, bij trager groeiende kuikens werd bij gemiddeld 3,9\% van de kuikens een vleugeldislocatie geconstateerd.

Bij beoordeling van de kuikens voor en na transport ( 4 koppels) werd geen toename in vleugeldislocaties gezien. Ook werd er geen toename in bloedingen of beschadigingen aan de poten en borst gezien na transport. Opvallend is dat het aandeel vleugelbloedingen toeneemt gedurende 
transport (bloedingen van $0,5-1 \mathrm{~cm}$ met $3.1 \%$ en bloedingen $>1 \mathrm{~cm}$ met $2,4 \%$ ). Het lijkt aannemelijk dat de bloedingen aan de vleugels worden veroorzaakt bij het vangen en tijd nodig hebben om te ontwikkelen en dus zichtbaar worden tijdens het transport.

Bij beoordeling van de kuikens in de slachtlijn werd een toename van bloedingen aan de poten (resp. met 1,3 en $2,9 \%$ ) en borst (ca 1,5\%) gezien. Ook het aandeel vleugeldislocaties neemt toe door het slachtproces van $2,9 \%$ naar $7,9 \%$ gemiddeld. Opvallend is dat het percentage vleugelbloedingen niet toeneemt door het slachtproces.

De gemiddelde totale welzijnsscore op het pluimveebedrijf was hoger voor koppels trager groeiende kuikens dan voor koppels reguliere kuikens. Gemiddeld gezien scoorden koppels trager groeiende kuikens beter ten opzichte van de koppels reguliere op alle kenmerken behalve op het percentage vermagerde kuikens. Er werd geen relatie gevonden tussen de totale welzijnsscore en vang- en laadletsel (vleugelbreuken en bloedingen), maar de score voor mortaliteit en voetzoollaesies leken wel geassocieerd te zijn met vang- en laadletsel. Deze verbanden dienen echter vanwege het lage aantal koppels in deze studie met de nodige voorzichtigheid te worden geïnterpreteerd. Het is daarom aan te bevelen om dit verder te onderzoeken in een groter aantal koppels.

Concluderend, na beoordeling van de kuikens direct na aankomst op de slachterij is duidelijk geworden dat vleugelbloedingen en vleugeldislocaties het meest voorkomend letsel is bij vleeskuikens. Gemiddeld gezien kwam vleugelletsel meer voor bij koppels trager groeiende dan bij koppels reguliere kuikens. Tussen individuele koppels was er echter grote variatie in percentage kuikens met vleugelletsel. Uit oogpunt van dierenwelzijn is verder onderzoek naar het reduceren van vleuggelletsel en dan met name naar het voorkomen van vleugeldislocaties noodzakelijk. 


\section{Aanleiding en achtergrond}

Pluimvee wordt als ze slachtrijp of aan het einde van hun productieve leven zijn in kratten of containers geladen, naar de slachterij vervoerd en geslacht. Daarbij komt het voor dat een deel van de dieren letsel zoals botbreuken, bloeduitstortingen of dislocaties oploopt of het transport niet overleeft, de zogenaamde 'Dead On Arrivals of DOA's'. Veel factoren lijken hierop van invloed te zijn, zoals bijvoorbeeld het houderijsysteem, de vangploeg of de vangmethode (handmatig of met een machine), het type en de staat van kratten of containers, de reisduur, rijd- en reisomstandigheden, de opvang en behandeling in de slachterij zoals uitkratten, aanhangen en natuurlijk de fitheid van het koppel (o.a. Chauvin et al., 2011; Kittelsen et al., 2015a; Kittelsen et al., 2015b; Langkabel et al., 2015; Jacobs et al., 2017a; b; Jacobs et al., 2017c; Kittelsen et al., 2017). Het is van belang om letsel en schade te voorkomen, door niet alleen te kijken naar de houderij van pluimvee, maar naar het gehele ketenproces inclusief het vangen, laden, transport, uitkratten en het slachtproces. Om dit te realiseren is een goed beeld van de grootste knelpunten in dit traject van belang.

Verwondingen zoals bloedingen, breuken en dislocaties, en DOA's worden op de slachterij bijgehouden en leiden tot opbrengstderving voor de slachterij én voor de pluimveehouder. Daarnaast is de mate van geconstateerd letsel in het kader van de dierwelzijnsinspectie voor de NVWA bepalend om maatregelen op te leggen aan of de pluimveehouder of de slachterij. Inzicht in de mate waarin letsel of schade voorkomt, en in welk stadium van het proces van vangen tot transport, draagt bij aan de ontwikkeling van instrumenten om letsel en schade aan de dieren respectievelijk het product te voorkomen.

Als we praten over ketenletsel is het van belang om vast te stellen waar de oorzaak ligt én om vast te stellen of we praten over letsel aan het levende dier of over schade aan het dode dier. Op basis van de differentiatie tussen letsel en schade zijn de mogelijkheden om te komen tot verbetering te benoemen. Goed onderscheid tussen de oorzaak van letsel aan levende dieren (verder te benoemen als vang en laadletsel) en schade door het slachtproces (verder te benoemen als slachtschade) is essentieel in het streven naar een verbetering van het dierenwelzijn en relevant voor maatregelen in het kader van de welzijnsinspectie.

Als één van de factoren die invloed heeft op letsel of schade wordt de fitheid van het koppel genoemd (Chauvin et al., 2011; Jacobs et al., 2017c; Kittelsen et al., 2017). Als er een instrument is waarmee eenvoudig de fitheid van het koppel bepaald kan worden en de fitheid van een koppel een relatie heeft met het optreden van letsel in het end-of-life traject (vangen, transport, ontladen), kan onderzocht worden hoe het letsel bij minder fitte koppels tot een minimum beperkt kan worden, zodat het welzijnsrisico gedurende de laatste levensfase wordt geminimaliseerd. Daarnaast is vermindering van letsel en schade een extra stimulans om te sturen op een goede fitheid van het koppel gedurende het leven op de boerderij. De Welfare Quality ${ }^{\circledR}$ welzijnsmonitor (Welfare Quality, 2009) kan als instrument worden gebruikt om het welzijn (inclusief de gezondheid) van een koppel vleeskuikens in beeld te brengen. De monitor geeft een totaalbeeld van het koppel waarbij meerdere welzijns- en gezondheidsaspecten worden meegenomen. Uit onderzoek is gebleken dat de meeste individuele metingen valide zijn, maar dat de zogenaamde 'eindscore' berekening (de totale welzijnsscore) voor een koppel niet gevoelig genoeg is (De Jong et al., 2015). Echter, door gebruik te maken van de individuele metingen en de scores per welzijnscriterium kan een goed beeld van het welzijn van een koppel verkregen worden (De Jong et al., 2015; Gocsik et al., 2016). 


\section{$1.1 \quad$ Doelstelling}

Het doel van dit onderzoek is tweeledig:

1. In kaart brengen in welke mate letsel of schade optreedt bij vleeskuikens als gevolg van handelingen in het 'end-of-life'-traject, en of er mogelijke verschillen zijn tussen koppels reguliere en trager groeiende vleeskuikens;

2. Onderzoeken of er een mogelijke relatie is tussen de fitheid van het koppel, vastgesteld met behulp van de Welfare Quality ${ }^{\circledR}$ welzijnsmonitor (Welfare Quality, 2009), en de mate waarin letsel optreedt gedurende de 'end-of-life' fase bij vleeskuikens.

In dit onderzoek zijn alleen koppels wegladers onderzocht. Het aantal koppels dat kon worden gemeten, zowel voor (1) als voor (2) is zodanig dat de resultaten van dit onderzoek als een eerste indicatie moeten worden beschouwd, die aanleiding kunnen geven voor vervolgonderzoek aan grotere aantallen koppels. 


\section{$2 \quad$ Literatuur}

In de fase van afleveren van pluimvee naar de slachterij kunnen we in relatie tot vang- en laadletsel 4 pre-slachtfasen onderscheiden; 1) primair bedrijf, 2) vangen en laden, 3) transport en 4) de wachtruimte op de slachterij. Het uitkratten, aanhangen en verdoven rekenen we tot het slachtproces.

\section{$2.1 \quad$ Primair bedrijf}

Fitheid:

In verordening (EG) Nr. 1/2005 is vastgelegd dat dieren alleen mogen worden getransporteerd als de dieren geschikt zijn voor het voorgenomen transport, en dat de dieren niet onnodig lijden. Dit betekent dat zieke en gewonde dieren niet of alleen onder voorwaarden mogen worden getransporteerd. Zeker dieren met breuken en dislocaties zijn in dit kader niet geschikt om te worden getransporteerd. Blootstellen van ziek of gewond pluimvee aan transport zal in de praktijk leiden tot een hoger DOA percentage (Nijdam et al., 2006, Kittelsen et al., 2015) en tot meer afkeuring en minder opbrengst.

Voer en wateronthouding:

Het is gebruikelijk om meerdere uren voor aanvang van het vangen de voerverstrekking te stoppen en kort voor het vangen de toegang tot water te stoppen. Voeronthouding is nodig om bezoedeling van dieren en karkassen aan de slachtlijn te voorkomen. Naast de positieve effecten van voer- en wateronthouding zijn er ook negatieve kanten. Te lange voeronthouding leidt tot stress (Nijdam et al, 2005b) en veroorzaakt gewichtsverlies, na verloop van tijd tot verlies van spiermassa en dus verlies van rendement (Delezie et al., 2007; Knowles et al., 1995; Lyon et al., 1991). Langere onthouding van water, zeker bij hoge temperaturen zal leiden tot dehydratie, hittestress gewichtsverlies en tot een hogere percentage DOA's.

\subsection{Vangen en laden}

Een belangrijke oorzaak voor het optreden van bloedingen, breuken, dislocaties en zelfs DOA's (Nijdam et al., 2006) is het vangen van pluimvee. De grote verschillen in gerapporteerde letsel en/of schade is opvallend en het is niet altijd duidelijk wanneer/waar in het traject het letsel of de schade is veroorzaakt. Wanneer schade wordt gescoord aan de slachtlijn, na verdoven en plukken, is het vaak niet duidelijk of er sprake is van vangletsel, transportletsel of slachtschade. Uit het onderzoek van Jacobs (2016) komt naar voren dat in het traject van houderij, vangen, transport en wachtruimte nagenoeg alle bloedingen, breuken en dislocaties tijdens het vangen en laden zijn veroorzaakt. Het totaal percentage dieren met vleugelschade na plukken was 1,95\% in het onderzoek van Jacobs terwijl in een studie van Langkabel et al., (2013) tot maximaal 15,3\% vleugelschade werd vastgesteld na plukken. In een onderzoek van Kittelsen et al. (2015) werd een toename van het percentage breuken gezien van $0,8 \%$ na vangen naar $2,4 \%$ na plukken.

Duidelijk is dat de vangploeg en vangmethode van invloed zijn op het percentage letsel en het type letsel. Knierim and Gocke (2003) constateerden bij mechanisch gevangen vleeskuikens een lager percentage bloedingen, breuken en dislocaties dan bij handmatig gevangen vleeskuikens. In andere studies werden juist meer bloedingen, breuken en dislocaties gevonden bij mechanisch gevangen vleeskuikens (Musilová et al., 2013).

Een derde belangrijke risicofactor lijkt het gewicht van de dieren te zijn, waarbij zware dieren meer beschadigingen oplopen dan lichte dieren (Langkabel et al., 2015). In dat onderzoek, uitgevoerd in Duitsland, was vooral de toename in vleugelbeschadigingen, gemiddeld $5 \%$ bij lichte dieren $(1,9 \mathrm{~kg})$ naar gemiddeld $12 \%$ bij zware dieren $(2,5 \mathrm{~kg})$ opvallend. 


\subsection{Transport}

Uit verschillende onderzoeken komt naar voren dat duur van transport, beladingsdichtheid en weersomstandigheden een oorzaak zijn voor mortaliteit (Petracci et al., 2005; Vecerek et al., 2006; Voslářová et al., 2007; Mitchel and Kettlewell 2009). Het aantal DOA's neemt vooral toe bij hoge temperaturen als gevolg van hittestress maar, hoewel in mindere mate, ook bij lage temperaturen (Vecerek 2006, Mitchel and Kettlewell 2009). Ook neemt het percentage DOA's toe met de transportafstand en dus met de transportduur. Voor vleeskuikens bijvoorbeeld steeg het aandeel DOA's van $0.15 \%$ bij $50 \mathrm{~km}$ transport naar 0.59\% bij $300 \mathrm{~km}$ transport (Voslarova et al., 2007). Het is niet duidelijk welke factor bij een langere transportafstand de belangrijkste rol speelt voor de stijging van het percentage DOA's. Het is te verwachten dat de combinatie van verminderde fitheid en de duur dat moeilijke omstandigheden (hitte, kou, uitputting, dehydratie) aanhouden bepalend zijn.

\subsection{Wachtruimte}

Van de specifieke bijdrage van de omstandigheden in de wachtruimte en de wachttijd op de slachterij op letsel en DOA's is niet veel bekend. In het onderzoek van Jacobs (2016) bleek de bijdrage van factoren na het vangen minimaal te zijn op het percentage letsel. Slachterijen richten hun wachtruimtes hier ook op in. Echter als de omstandigheden tijdens verblijf in de wachtruimte niet goed zijn is het te verwachten dat dit ook een effect zal hebben op de dieren, zeker bij minder fitte dieren. 


\section{Vaststellen vang- en laadletsel in de praktijk en de mogelijke relatie met de fitheid van het koppel}

\subsection{Vang- en laadletsel: materiaal en methoden}

Dit hoofdstuk beschrijft de wijze waarop vang- en laadletsel is vastgesteld, de proefopzet en hoe de waarnemingen zijn uitgevoerd. Bij het vaststellen van vang- en laadletsel zijn de volgende 2 definities uitgangspunt voor de beoordeling:

Definitie vang- en laadletsel: alle letsel aan levende dieren dat is opgetreden voordat de dieren op de slachterij worden uit de containers worden gehaald en aangehangen aan de slachtlijn.

Definitie slachtschade: alle letsel en schade aan het dier dat is opgetreden vanaf het moment dat de dieren uit de container worden gehaald of gekanteld $n$ worden aangehangen aan de slachtlijn tot en met het plukken.

Definitie schade en letsel door het vang- en laadproces: combinatie van vang- en laadletsel en slachtschade.

\subsection{Proefopzet}

Naar aanleiding van de literatuurverkenning is besloten om letsel vast te stellen aan 16 reguliere vleeskuikenkoppels en 16 trager groeiende vleeskuikenkoppels. Er is gekozen om het letsel vast te stellen in de wachtruimte van de slachterij direct na aankomst op de slachterij. Uitgangspunt hierbij is dat het transport op zich geen of een kleine oorzaak zal zijn voor het ontstaan van letsel. Verkennend wordt bij een beperkt aantal koppels (4) zowel het letsel direct na vangen op het primaire bedrijf beoordeeld en direct na afloop van het transport in de wachtruimte van de slachterij nogmaals beoordeeld. Daarnaast wordt met behulp van de Welfare Quality ${ }^{\circledR}$ monitor (zie 3.3) bij 8 van de 16 reguliere- en 8 van de 16 trager groeiende koppels een beoordeling van de fitheid van het koppel uitgevoerd. Deze stalbeoordeling wordt \pm 4 dagen voor afleveren uitgevoerd. Bij de 4 koppels waar vang- en laadletsel direct voor transport is beoordeeld is ook een stalbeoordeling uitgevoerd. Vier slachterijen (A t/m D) participeren in het onderzoek naar ketenletsel, 2 met gas verdoven ( $A$ en $B$ ) en 2 met elektrisch verdoven ( $C$ en D). Slachterij A slacht zowel reguliere als trager groeiende kuikens. Slachterij B, C en D slachten uitsluitend reguliere kuikens. Deze 4 slachterijen liggen verspreid over Nederland. De verdeling van de koppels en de beoordelingsmomenten zijn weergegeven in Tabel 1.

Tabel 1: Proefopzet (aantal koppels per slachterij per type kuiken dat is beoordeeld, onderverdeeld in aantal beoordelingsmomenten vóór slachten).

\begin{tabular}{|c|c|c|c|c|c|c|c|}
\hline Kuiken & & Slachterij & A & $\mathrm{B}$ & $\mathrm{C}$ & $\mathrm{D}$ & \\
\hline & & verdoving & gas & gas & elektr. & elektr. & totaal \\
\hline & beoordeling in & & & & & & \\
\hline Regulier & wachtruimte & & 2 & 2 & 2 & 2 & 8 \\
\hline Regulier & wachtruimte+stal & & & 2 & 2 & 2 & 6 \\
\hline \multirow[t]{2}{*}{ Regulier } & wachtruimte+na & & & & 2 & & 2 \\
\hline & vangen+stal & & & & & & \\
\hline Trager groeiend & wachtruimte & & 8 & & & & 8 \\
\hline Trager groeiend & wachtruimte+stal & & 6 & & & & 6 \\
\hline \multirow[t]{2}{*}{ Trager groeiend } & wachtruimte+na & & 2 & & & & 2 \\
\hline & vangen+stal & & & & & & \\
\hline Totaal & & & 18 & 4 & 6 & 4 & 32 \\
\hline
\end{tabular}




\subsection{Beoordelen van vang- en laadletsel}

Beoordeling vang- en laadletsel in wachtruimte slachterij:

Direct na aankomst van de kuikens op de slachterij zijn er per koppel 2 volledig gevulde containers aangewezen en apart gezet voor het beoordelen van letsel aan de levende dieren. De 2 containers werden van een verschillende plek van de vrachtwagen gehaald om te voorkomen dat kuikens uit een specifiek deel van de stal werden beoordeeld. De containers werden gecontroleerd op eventuele beschadigingen. De kuikens werden vervolgens geïnspecteerd om een algemene indruk te krijgen van eventuele problemen zoals indicaties voor koude of hitte stress en eventueel beklemde kuikens. Van de 2 geselecteerde containers zijn alle dieren uit 1 helft van de container beoordeeld op bloedingen, open of gesloten dislocaties, en breuken. Wat bloedingen betreft is onderscheid gemaakt tussen bloedingen van 0,5-1 cm in doorsnee en bloedingen groter dan $1 \mathrm{~cm}$. De vleugeltippen zijn buiten beschouwing gelaten. Reden hiervoor is dat vleugeltippen moeilijk objectief zijn te beoordelen aan het levende dier. Daarnaast is in het slachtproces niet te beoordelen of rode vleugeltippen zijn veroorzaakt voor of in het slachtproces.

Het aantal beoordeelde dieren, het aantal beschadigingen, DOA's en rugliggers is per lade genoteerd (zie Bijlage 1). De beoordelingen zijn uitgevoerd door 3 onderzoekers van WLR.

$\mathrm{Er}$ is per categorie van letselvorm weergegeven bij hoeveel slachtkuikens dit is geconstateerd. Bij het beoordelen van het letsel werd indien mogelijk aangegeven of het letsel vers is of al eerder is ontstaan (voor vangen).

In het beoordelingsprotocol is alle letsel aan de kuikens gescoord (Tabel 2). Het beoordelingsprotocol is anders dan de systematiek die wordt gehanteerd door de toezichthouder voor het vaststellen van vang en laadschade volgens het Werkvoorschrift Toezicht op welzijn van pluimvee en konijnen code WLZVL-030 (www.nvwa.nl). Door de toezichthouder wordt vang en laadletsel beoordeeld in de slachtlijn op basis van de omvang en de kleur van de bloeding. Hiermee wordt geen direct onderscheid gemaakt naar type letsel. Om een breder beeld te krijgen van het type letsel en daarmee beter te kunnen onderscheiden of er sprake is van letsel of slachtschade is er gekozen voor een breder beoordelingsprotocol waarbij dieren zowel voor als na het slachten worden beoordeeld.

Tabel 2: Afkortingen voor de gescoorde letsels.

\begin{tabular}{ll}
\hline Afkorting & Letsel \\
\hline Bbl_m & Borstbloeding $0,5-1 \mathrm{~cm}$ \\
Bbl_g & Borstbloeding $>1 \mathrm{~cm}$ \\
Vbl_m & Vleugelbloeding $0,5-1 \mathrm{~cm}$ \\
Vbl_g & Vleugelbloeding $>1 \mathrm{~cm}$ \\
Pbl_m & Pootbloeding $0,5-1 \mathrm{~cm}$ \\
Pbl_g & Pootbloeding $>1 \mathrm{~cm}$ \\
Vdis & Vleugel dislocatie \\
Vbr & Vleugel breuk \\
Pdis & Poot dislocatie \\
Pbr & Poot breuk \\
\hline
\end{tabular}

De slachtkuikens zijn vervolgens met dezelfde bezettingsgraad per lade in één andere container geplaatst. De volledig gevulde container werd gemerkt en aansluitend bij hetzelfde koppel volgens het reguliere proces van de slachterij geslacht en beoordeeld na plukken. De waarnemingen na plukken zijn uitgevoerd aan de slachtlijn bij een reguliere lijnsnelheid. De kuikens zijn aan de slachtlijn op dezelfde kenmerken beoordeeld als in de wachtruimte.

\subsubsection{Beoordeling aandeel letsel door transport}

Om inzicht te krijgen in de bijdrage die transport heeft op de mate van letsel zijn er bij 4 koppels vleeskuikens direct na vangen en laden en voor opladen op de vrachtwagen 2 halve containers op dezelfde wijze beoordeeld als in de wachtruimte van de slachterij. Bij aankomst op de slachterij zijn dezelfde dieren nogmaals beoordeeld. Daarnaast is met behulp van dataloggers bij deze vier koppels tijdens het transport de temperatuur geregistreerd op 3 verschillende locaties op de oplegger 
(Figuur 1). Eén meting in de container bovenin in het midden van de oplegger direct achter de cabine, één meting in het midden van de oplegger en halverwege de hoogte van de containers en één meting onderin de container aan de buitenzijde van de oplegger. Daarnaast werd reistijd en route typering vastgelegd.

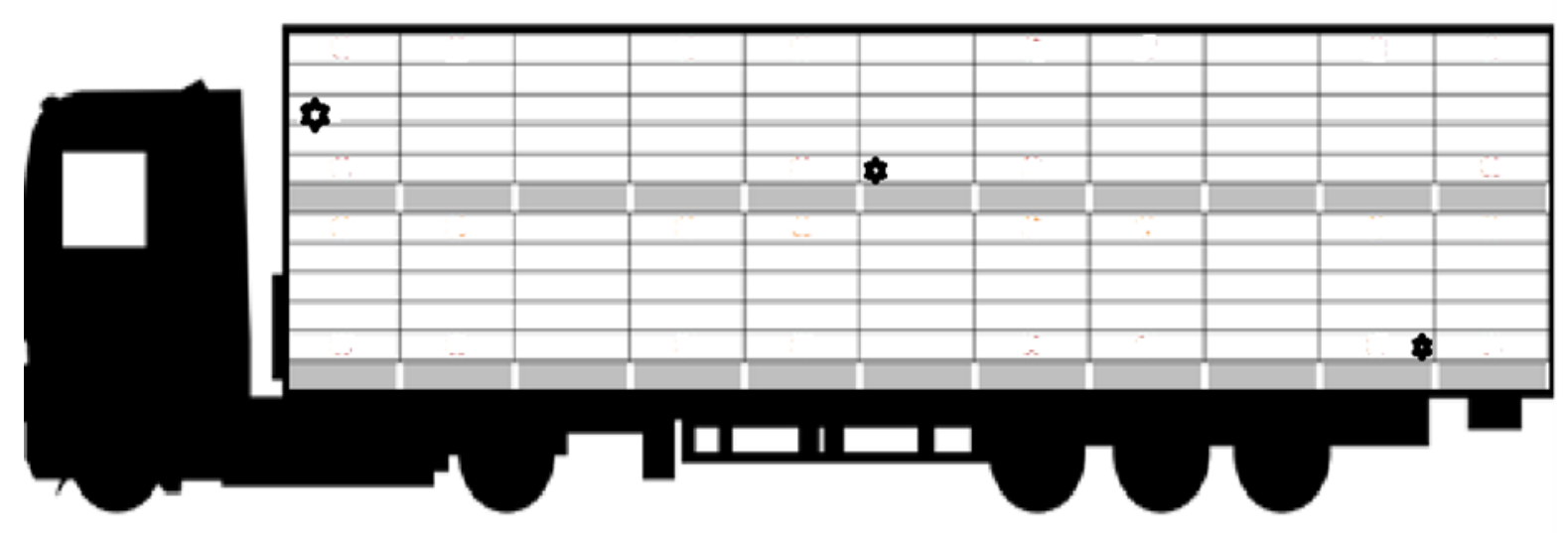

Figuur 1: Zijaanzicht vrachtwagen en locatie van temperatuurloggers.

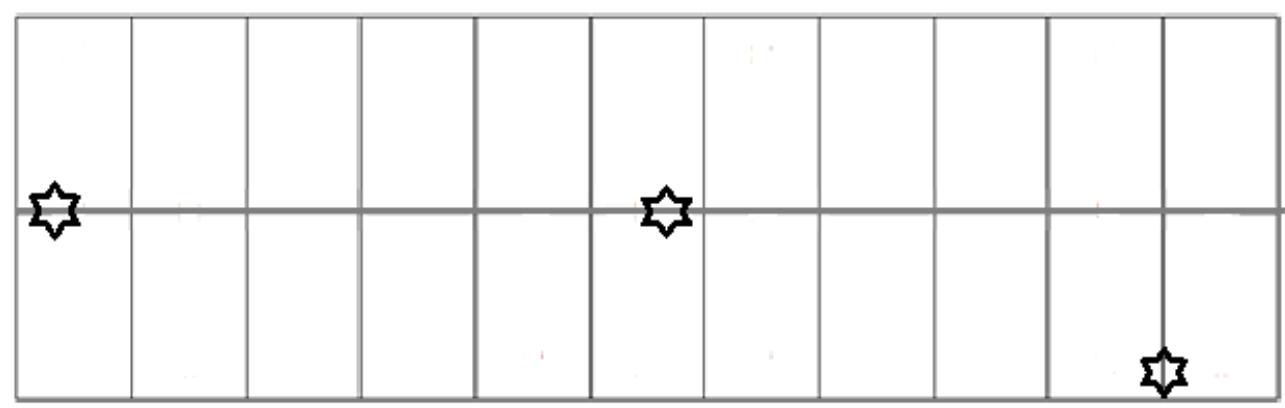

Figuur 2: Bovenaanzicht van locatie van de temperatuurloggers in de containers op de vrachtwagen.

\subsubsection{Beoordeling schade na slachten en plukken}

De in de wachtruimte beoordeelde kuikens zijn zo kort mogelijk na de plukker en overhanger opnieuw beoordeeld op open of gesloten dislocaties, breuken en bloedingen. De vleugeltippen zijn wederom buiten beschouwing gelaten. De beoordeling is door dezelfde 3 onderzoekers uitgevoerd in de panklaar afdeling met hulp van een ervaren (IKB-)medewerker van de slachterij die meestal de bloedingen aan de vleugels scoorde.

Alle overige gegevens die beschikbaar zijn van het koppel zijn door de slachterij aangeleverd.

\subsubsection{Berekening en data analyse}

Significantie van verschillen tussen regulier en traag groeiende kuikens zijn berekend met een student T-toets onderzocht. Gezien het beperkt aantal observaties is er geen statistische analyse uitgevoerd op bijdrage door transport en vangmethode.

Correlaties tussen vang en laadletsel en kuikengewicht en bezettingsgraad in de container zijn bepaald met behulp van de non-parametrische Spearman Rank Correlation test. Statische berekeningen zijn uitgevoerd met Genstat. 


\subsection{Beoordeling welzijn van het koppel}

\subsubsection{Koppels}

In dit onderdeel van het project is een beoordeling van het welzijn van het koppel met behulp van de Welfare Quality ${ }^{\circledR}$ welzijnsmonitor (zie 3.4.2) uitgevoerd bij een selectie van koppels. Vanwege een beperking van de financiële middelen zijn 9 koppels reguliere kuikens ( 1 extra koppel dan voorzien) en 8 koppels trager groeiende vleeskuikens beoordeeld zoals aangegeven in Tabel 1, dus een subset van de koppels beoordeeld m.b.t. vang- en laadletsel. De koppelbeoordelingen zijn uitgevoerd door twee getrainde waarnemers van Wageningen Livestock Research.

\subsubsection{Welzijnsmonitor vleeskuikens}

In dit onderzoek is de fitheid van de koppels beoordeeld met behulp van de Welzijnsmonitor Vleeskuikens (Welfare Quality, 2009) rond 4 dagen voor het slachten van het koppel (wegladen). Daarbij zijn, op basis van eerdere projecten waarin de validiteit en de haalbaarheid van de welzijnsmonitor is bepaald (De Jong et al., 2011; De Jong et al., 2015), enkele aanpassingen doorgevoerd. De indicatoren die voor ieder koppel zijn gemeten zijn weergegeven in Tabel 3.

Tabel 3: Overzicht van de indicatoren gemeten met behulp van de welzijnsmonitor vleeskuikens (Welfare Quality, 2009) en een korte toelichting op de metingen.

\begin{tabular}{|c|c|c|}
\hline Welzijnscategorie & Meting & Toelichting \\
\hline \multirow[t]{3}{*}{ Goede gezondheid } & $\begin{array}{l}\text { (afwezigheid van) } \\
\text { vermagerde kuikens }{ }^{1} \\
\text { (afwezigheid van) } \\
\text { voetzoollaesies } \\
\text { (afwezigheid van) } \\
\text { hakdermatitis } \\
\text { Schoon/bevuild } \\
\text { (afwezigheid van) } \\
\text { huidbeschadigingen } \\
\text { (afwezigheid van) } \\
\text { borstirritatie }\end{array}$ & $\begin{array}{l}\text { Deze metingen worden uitgevoerd door middel van } \\
\text { inspectie van minimaal } 100 \text { kuikens verdeeld over } \\
\text { de stal, ieder kuiken wordt gescoord voor de } \\
\text { genoemde kenmerken volgens het Welfare Quality } \\
\text { protocol. Gescoord wordt of deze kenmerken } \\
\text { afwezig dan wel aanwezig zijn en in welke mate. }\end{array}$ \\
\hline & (afwezigheid van) uitval & $\begin{array}{l}\text { Eerste week - totaal; uitval door selectie of } \\
\text { natuurlijke dood. }\end{array}$ \\
\hline & Locomotie score & $\begin{array}{l}\text { Dit wordt gescoord bij minimaal } 150 \text { kuikens } \\
\text { verdeeld over de stal volgens het Welfare Quality } \\
\text { protocol. }\end{array}$ \\
\hline \multirow[t]{2}{*}{ Goede huisvesting } & 'thermal comfort' & $\begin{array}{l}\text { Percentage kuikens panting/huddling, incl de } \\
\text { (overdekte) uitloop. }\end{array}$ \\
\hline & $\begin{array}{l}\text { Maximale } \\
\text { bezettingsdichtheid }\end{array}$ & $\begin{array}{l}\text { Maximale bezettingsdichtheid bepaald op basis van } \\
\text { gewicht en aantal aanwezige kuikens. }\end{array}$ \\
\hline \multirow[t]{2}{*}{ Goed gedrag } & Gebruik (overdekte) uitloop & $\begin{array}{l}\text { Uitloop gebruikt ja/nee en percentage kuikens in } \\
\text { uitloop. }\end{array}$ \\
\hline & $\begin{array}{l}\text { Positief gedrag: gebruik } \\
\text { verrijking (indien aanwezig), } \\
\text { comfortgedrag, stofbaden } \\
\text { en scharrelen }{ }^{1}\end{array}$ & $\begin{array}{l}\text { Scoren }(\mathrm{ja} / \mathrm{nee}) \text { of de gedragingen worden } \\
\text { waargenomen gedurende het bezoek. }\end{array}$ \\
\hline
\end{tabular}

\footnotetext{
${ }^{1}$ Deze metingen zijn aangepast t.o.v. de versie in de Jong et al. (2016). Percentage vermagerde kuikens vervangt vermagering tijdens afkeur in de slachterij (wordt niet standaard gemeten) en het aantal kuikens per drinker (geen valide indicator). Positief gedrag vervangt de Qualitative Behaviour Assessment (geen valide indicator).
}

Tabel 3 is aangevuld met een metingen die niet binnen de Welzijnsmonitor vallen, maar wel van belang zijn in relatie tot het welzijn van het koppel en/of het vaststellen van letsel vanaf het vangen van de kuikens (op voorwaarde dat ze beschikbaar worden gesteld door de slachterij of pluimveehouder): antibioticagebruik, afkeur\%, uniformiteit\%, DOA\%, registratie afwijkingen door 
slachterij (slachterijscore voetzoollaesies, brandhakken, scabby hips). Tevens wordt bij het bezoek aan het bedrijf een aantal algemene kenmerken geregistreerd zoals het ras, aantal kuikens opgezet, aantal keren uitladen, reden van selectie. Dit om een zo compleet mogelijk beeld van het welzijn, inclusief de gezondheid van het koppel te krijgen.

Iedere vleeskuikenhouder kreeg zo snel mogelijk na de beoordeling van het koppel een overzicht toegestuurd van de resultaten van het koppel. Hierbij is weergegeven per systeem (regulier vs. trager groeiende kuikens) hoe het koppel presteerde ten opzichte van eerder gemeten koppels (De Jong et al., 2015). Vanwege het geringe aantal koppels binnen dit project leek benchmarking met de andere koppels in dit project niet zinvol, ook omdat de tijdspanne van het hier gerapporteerde project relatief groot was i.v.m. een tijdelijk bezoekverbod vanwege Aviaire Influenza. Een voorbeeld van deze terugkoppeling is voor een regulier en trager groeiend kuikens weergegeven in Bijlage 2.

\subsubsection{Berekeningen scores}

Om een correlatie te berekenen tussen de mate waarin letsel is gemeten bij de koppels en de fitheid van het koppel, is allereerst voor de individuele kenmerken een index en een score berekend volgens Welfare Quality ${ }^{\circledR}$ (WelfareQuality, 2009), analoog als is uitgevoerd door Gocsik et al. (2016). Dit houdt in dat in de gevallen dat er sprake is van een scoringssysteem met meerdere klassen, een weging is uitgevoerd om van een proportie kuikens binnen een klasse te komen tot één enkele score voor een indicator. Vervolgens is deze index omgerekend naar een score tussen 0 en 100, zodat alle scores voor de afzonderlijke indicatoren op een schaal van 0-100 worden weergegeven. Des te hoger de score, des te beter. Voor de berekeningen van de index en de score verwijzen we naar Welfare Quality ${ }^{\circledR}$ (Welfare Quality, 2009). Voor enkele nieuwe indicatoren was nog geen score door Welfare Quality ${ }^{\circledR}$ ontwikkeld. Het gaat te ver om binnen dit project een nieuwe scoremethodiek te ontwikkelen. Daarom is voor de volgende indicatoren een berekening aangehouden zoals ook voor eerdere of gelijksoortige indicatoren geldt:

- $\quad \%$ vermagerde kuikens: score overgenomen uit protocol voor \% emaciation binnen afkeur;

- Gedrag: per gedragscategorie (gebruik verrijking, stofbaden, poetsen en scharrelen) die is waargenomen is 25 punten gegeven, in totaal kan een maximum van 100 punten worden verkregen (o.a. analoog aan uitloopgebruik in protocol);

- Verwondingen: als bevuiling (zelfde aantal klassen).

\subsubsection{Berekeningen correlaties}

Om een mogelijke relatie tussen de het welzijn van het koppel en vang- en laadletsel te bepalen, zijn de volgende categorieën vang- en laadletsel meegenomen: totaal percentage bloedingen, totaal percentage dislocaties, totaal percentage vleugeldislocaties plus vleugelbreuken. Voor de overige gemeten kenmerken in de wachtruimte waren teveel nullen in de dataset (betreffend letsel of schade werd niet waargenomen bij dit koppel), of leek het niet zinvol om onderscheid te maken tussen categorieën (bloedingen). Daarnaast is het percentage DOA zoals gemeld door de slachterij meegenomen.

Bovengenoemde categorieën vang- en laadletsel zijn gerelateerd aan: totale welzijnsscore van het koppel; voetzoollaesiescore per koppel (deze wordt gezien als maat voor het welzijn van een koppel kuikens en als zodanig gehanteerd in de vleeskuikenrichtlijn); de score voor uitval (inclusief selectie) per koppel en de locomotie-score van het koppel.

Alle correlaties zijn afzonderlijk voor de koppels trager groeiende kuikens en de koppels reguliere kuikens bepaald met behulp van de non-parametrische Spearman Rank Correlation test in Genstat (v1.17). Vanwege het geringe aantal koppels moeten de resultaten van de analyse met enige voorzichtigheid bekeken worden. $\mathrm{R}^{2}>0.3$ of $\mathrm{R}^{2}<-0.3$ (matige correlatie, (de Jong et al., 2016)) wordt gezien als een aanleiding om verder onderzoek uit te voeren in een groter aantal vleeskuikenkoppels. 


\section{$4 \quad$ Resultaten}

\subsection{Realisatie waarnemingen}

Uit de realisatie blijkt dat de streefopzet grotendeels is gerealiseerd (Tabel 4). Bij slachterij C zijn 2 koppels meer en bij slachterij D 2 koppels minder beoordeeld dan was gepland. Er zijn 9 bedrijfsbeoordelingen uitgevoerd voor reguliere kuikens en 8 bedrijfsbeoordelingen voor trager groeiende kuikens. Deze kleine afwijkingen in aantallen hebben geen consequenties voor de analyse van de resultaten. Voor de indicatie van het transportletsel zijn 2 koppels beoordeeld op slachterij $A$ en 2 op slachterij C. Van de 32 koppels zijn 30 koppels handmatig uit de stal gevangen. De 2 koppels van slachterij $C$ waarvan ook het letsel voor en na transport is beoordeeld zijn met een vangmachine (Apollo Universal) gevangen en in de containers geladen. Van de 4 koppels bij slachterij D die alleen in de wachtruimte zijn beoordeeld, zijn er 2 afkomstig uit een patio-systeem. Alle overige 30 koppels zijn afkomstig uit conventionele stallen.

Tabel 4: realisatie aantal beoordeelde koppels per slachterij per type kuiken, onderverdeeld in beoordelingsmomenten vóór slachten.

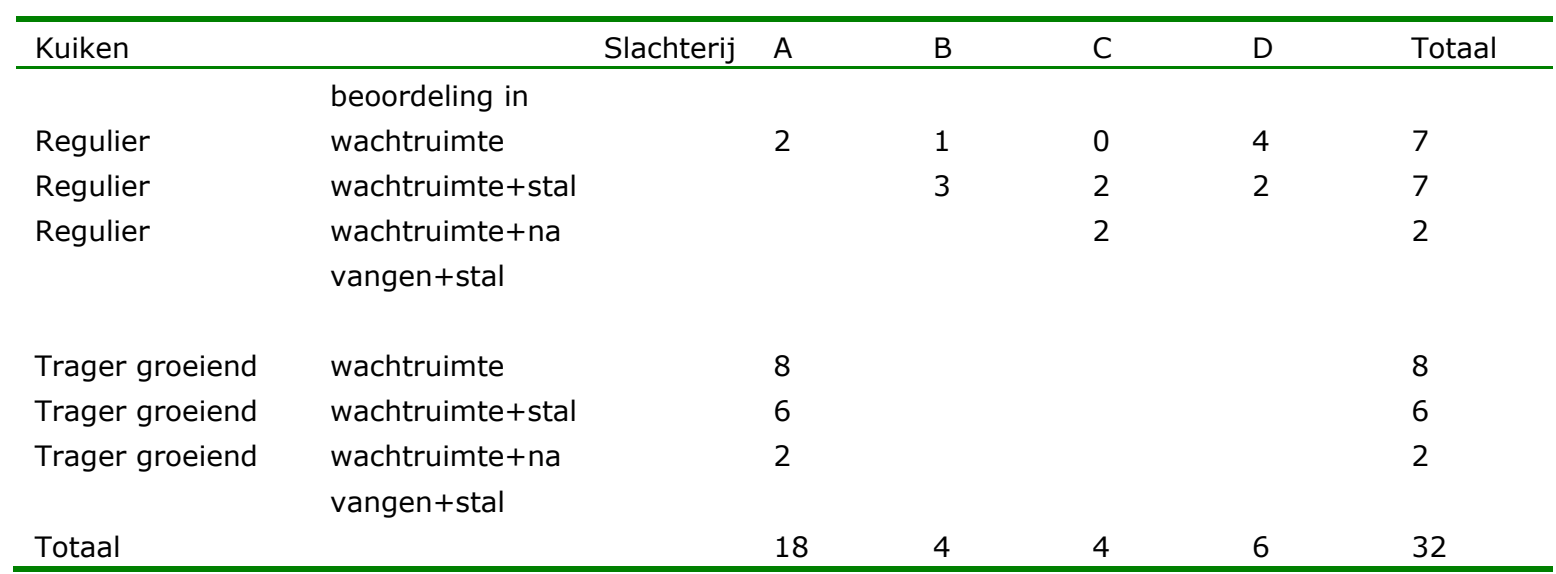

\subsection{Vang- en laadletsel}

In totaal zijn ruim 9000 vleeskuikens in de wachtruimte beoordeeld op letsel. Het percentage van de kuikens met bloedingen $(0,5-1 \mathrm{~cm}$ en $>1 \mathrm{~cm})$ aan de borst, de vleugels en de poten, dislocaties en breuken van vleugels én dislocaties en breuken van poten na vangen en laden is een gemiddelde over alle 32 koppels verdeeld over 4 slachterijen (zie Figuur 3). In een container zaten gemiddeld 281,6 vleeskuikens met een standaarddeviatie van 59,6. De kuikens zijn verdeeld over 8 of 10 lades afhankelijk van het containersysteem van de respectievelijke slachterij. De gebruikte containers in dit onderzoek waren in goede staat zonder noemenswaardige beschadigingen. 


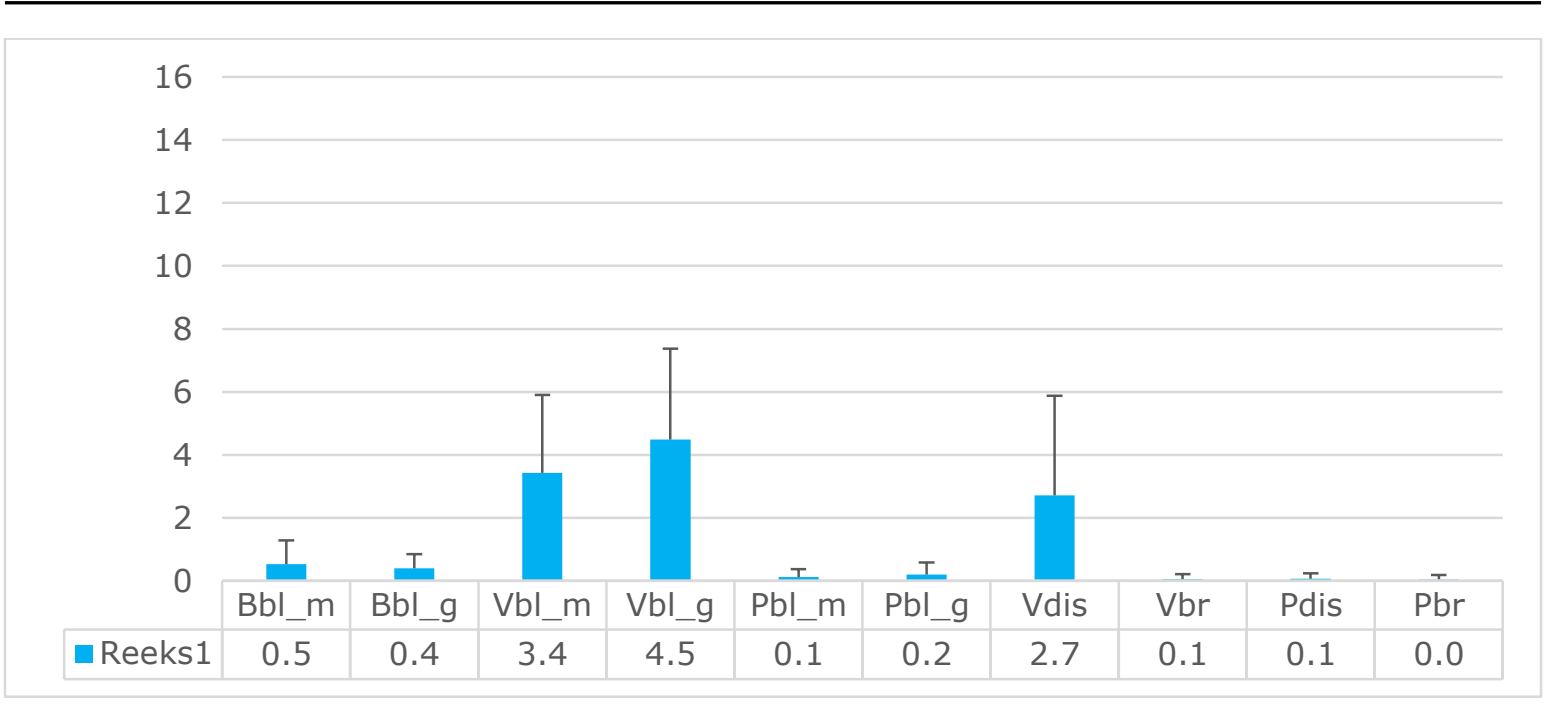

Figuur 3: Gemiddeld percentage kuikens met bloedingen $(0,5-1 \mathrm{~cm}$ en $>1 \mathrm{~cm})$ aan de borst, de vleugels en de poten, dislocaties en breuken van vleugels én dislocaties en breuken van poten na vangen en laden (gescoord bij levende dieren bij aankomst slachterij).

Bloedingen aan de vleugels van 0,5 tot $1 \mathrm{~cm}$ of van $>1 \mathrm{~cm}$ zijn met respectievelijk $3,4 \%$ en $4,5 \%$ het meest voorkomende letsel bij de kuikens na aankomst op de slachterij.

Bij beoordeling in de wachtruimte is bij gemiddeld $2,7 \%$ van de kuikens een dislocatie van één vleugel waargenomen. Bij 1 dier is een dislocatie van beide vleugels waargenomen. Opvallend is dat bij 1 koppel bij $18,1 \%$ van de dieren een dislocatie is geobserveerd. Uit de koppelgegevens kan geen verklaring worden gevonden voor dit hoge percentage. In de overige 31 koppels varieerde het percentage vleugeldislocaties van 0,4 tot $5,4 \%$. Bij vrijwel alle dislocaties gaat het om een gesloten dislocatie. In $0,1 \%$ van de gevallen ging de dislocatie gepaard met een open wond met een maximum van 3 gevallen in 1 container. Een dislocatie van de vleugel gaat in 95\% van de gevallen gepaard met een bloeding groter dan $1 \mathrm{~cm}$. Meer dan de helft van de grote bloedingen aan de vleugel gaat samen met een dislocatie. Vleugelbreuken, pootbreuken en pootdislocaties zijn gevonden in $<0,1 \%$ van de dieren.

In 6 koppels is één kuiken aangetroffen met oud letsel, dus ontstaan in de houderij periode. Deze letsels waren: een ontsteking op de rug, een bloeding in een vleugel, twee keer een bloeding aan de borst, een ontstoken gat in een vleugel en een wond.

Er is één keer 1 DOA met een beklemde kop waargenomen en 1 keer een kuiken met een beklemde vleugel. In 9 containers zijn 1 of 2 DOA's aangetroffen, het DOA percentage in de beoordeelde containers is daarmee $0,13 \%$. In de terugkoppeling van de koppelgegevens door de slachterij wordt een gemiddeld DOA percentage van $0,07 \%$ gerapporteerd. Opgemerkt moet worden dat het DOA\% van de slachterij de score is over het gehele koppel en dat de waarnemingen voor het onderzoek een steekproef zijn.

\subsubsection{Reguliere versus trager groeiende kuikens}

Het percentage letsel bij de reguliere kuikens is het gemiddelde van 16 koppels verdeeld over 4 slachterijen en het percentage letsel bij de trager groeiende kuikens is het gemiddelde van 16 koppels op 1 slachterij (zie Figuur 4). De reguliere kuikens zijn bij afleveren gemiddeld 39,8 dagen oud en wegen gemiddeld 2517 gram. De trager groeiende kuikens zijn bij afleveren gemiddeld 52,9 dagen oud en wegen gemiddeld 2511 gram. In de onderzochte containers zitten per lade gemiddeld 33,4 reguliere kuikens en 33,6 trager groeiende kuikens. Deze bezetting komt overeen met gemiddeld 82,8 $\mathrm{kg} /$ lade voor reguliere kuikens en $84,3 \mathrm{~kg} /$ lade bij trager groeiende kuikens.

Bij de koppels reguliere kuikens komen vaker middelgrote bloedingen voor dan bij de koppels trager groeiende kuikens, respectievelijk $4,2 \%$ en $2,7 \%$ gemiddeld. Het percentage dislocaties bij trager groeiende kuikens was significant $(p=0.03)$ hoger $(3,9 \%$ gem.) dan bij regulier groeiende kuikens (1,5\% gem.). Als we het koppel met $18,1 \%$ dislocaties buiten beschouwing laten neemt de 
significantie toe $(p=0.004)$. Het percentage dislocaties heeft geen correlatie met het gewicht van de dieren $\left(r^{2}=0,11\right)$ of de bezettingsdichtheid in de containers $\left(r^{2}=0,01\right)$.

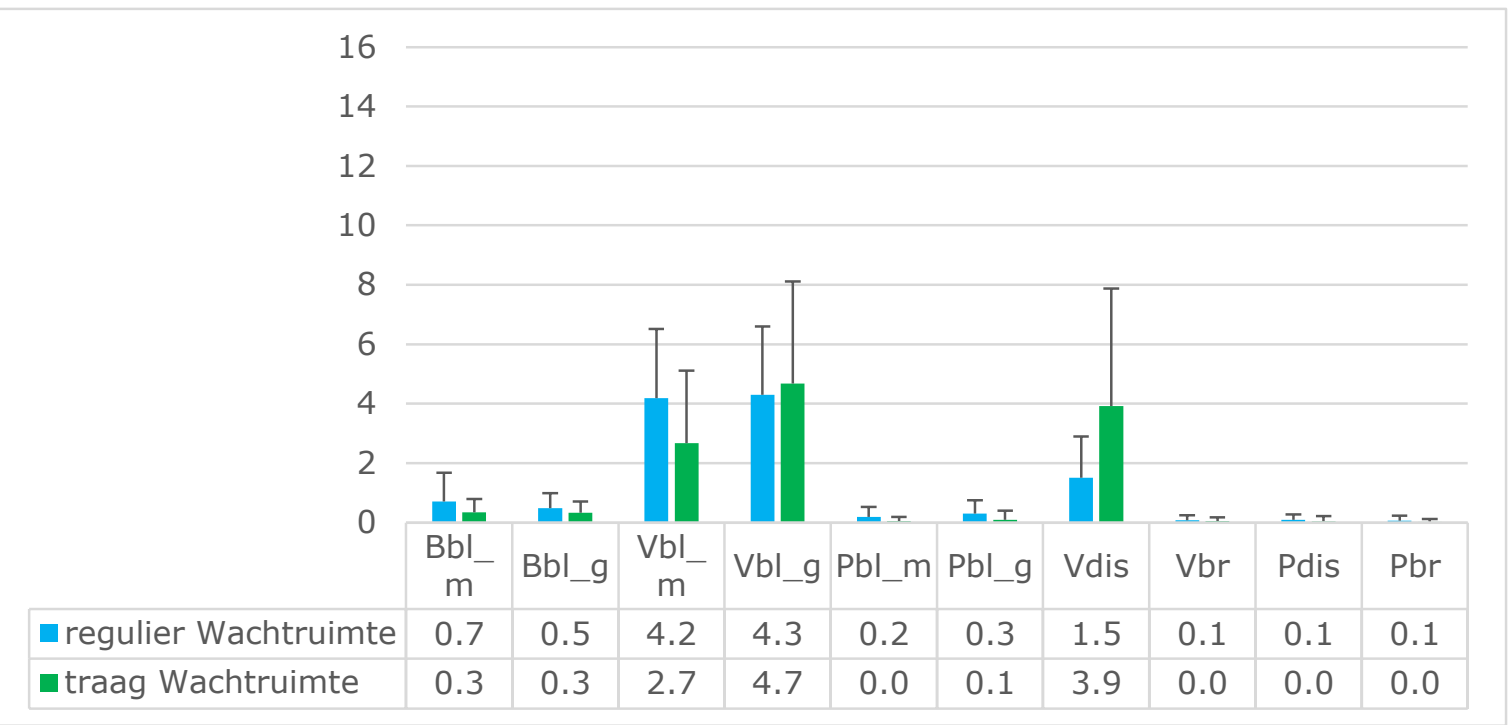

Figuur 4: Gemiddeld percentage reguliere en trager groeiende kuikens met bloedingen (0,5-1 cm en $>1 \mathrm{~cm}$ ) aan de borst, de vleugels en de poten, dislocaties en breuken van vleugels én dislocaties en breuken van poten na vangen en laden.

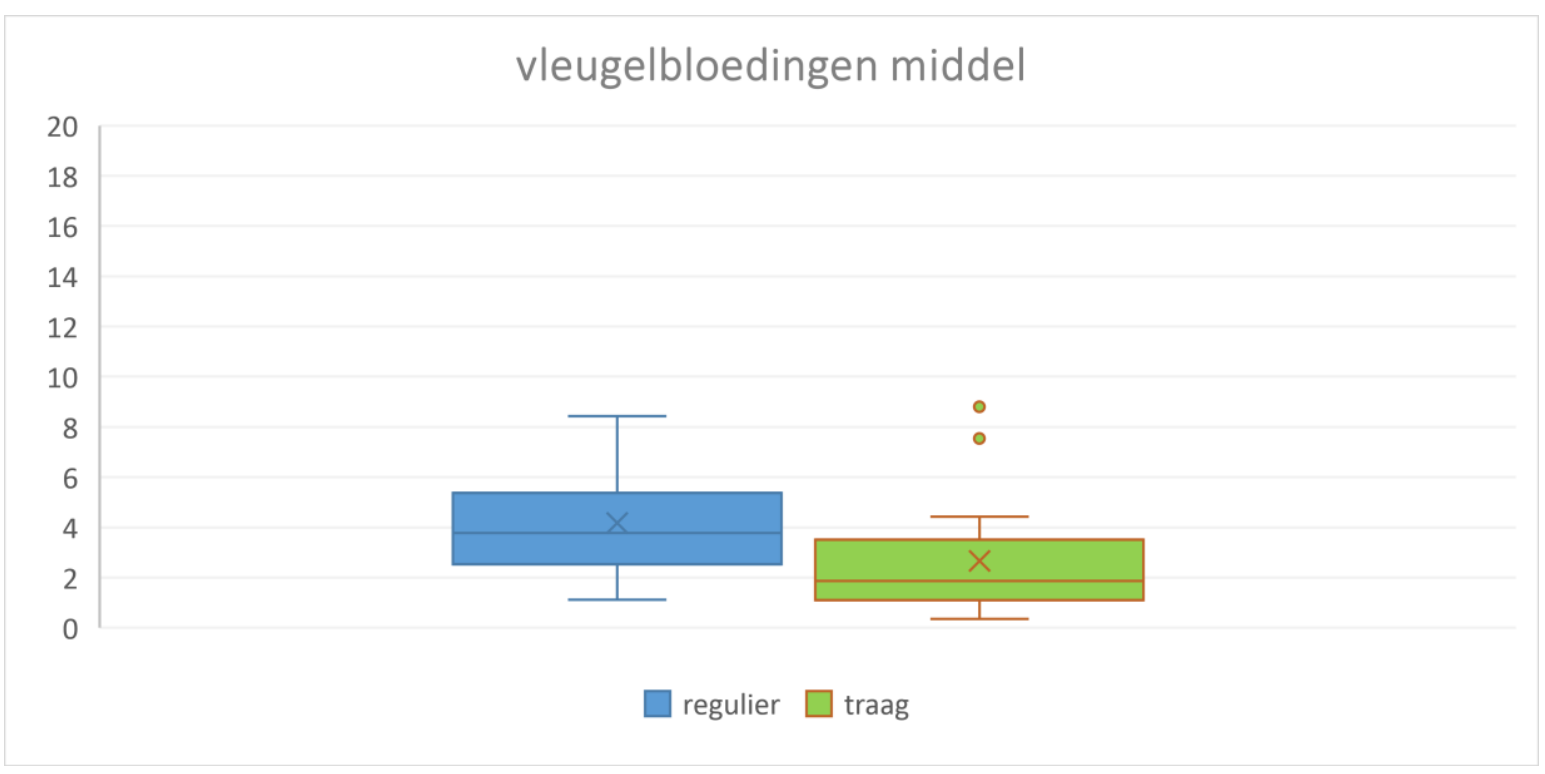

Figuur 4a: Boxplot waarin de mediaan (-), het gemiddelde $(x)$ en de laagste en hoogste waarde van de vleugelbloedingen tussen 0,5-1 cm zijn weergegeven. Uitbijters zijn weergegeven met punten. 


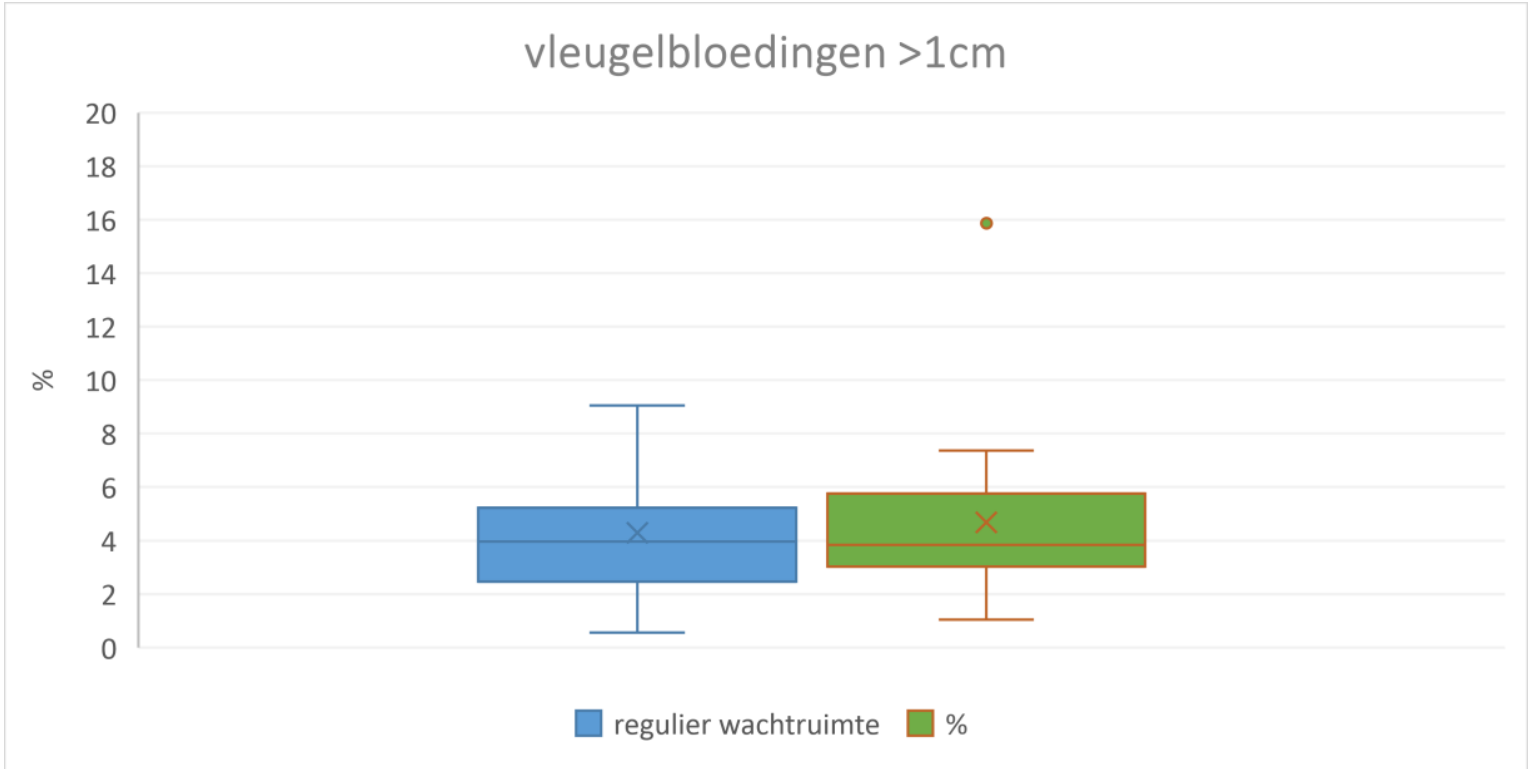

Figuur 4b: Boxplot waarin de mediaan (-), het gemiddelde $(x)$ en de laagste en hoogste waarde van de vleugelbloedingen $>1 \mathrm{~cm}$ zijn weergegeven. De punt geeft een uitbijter weer.

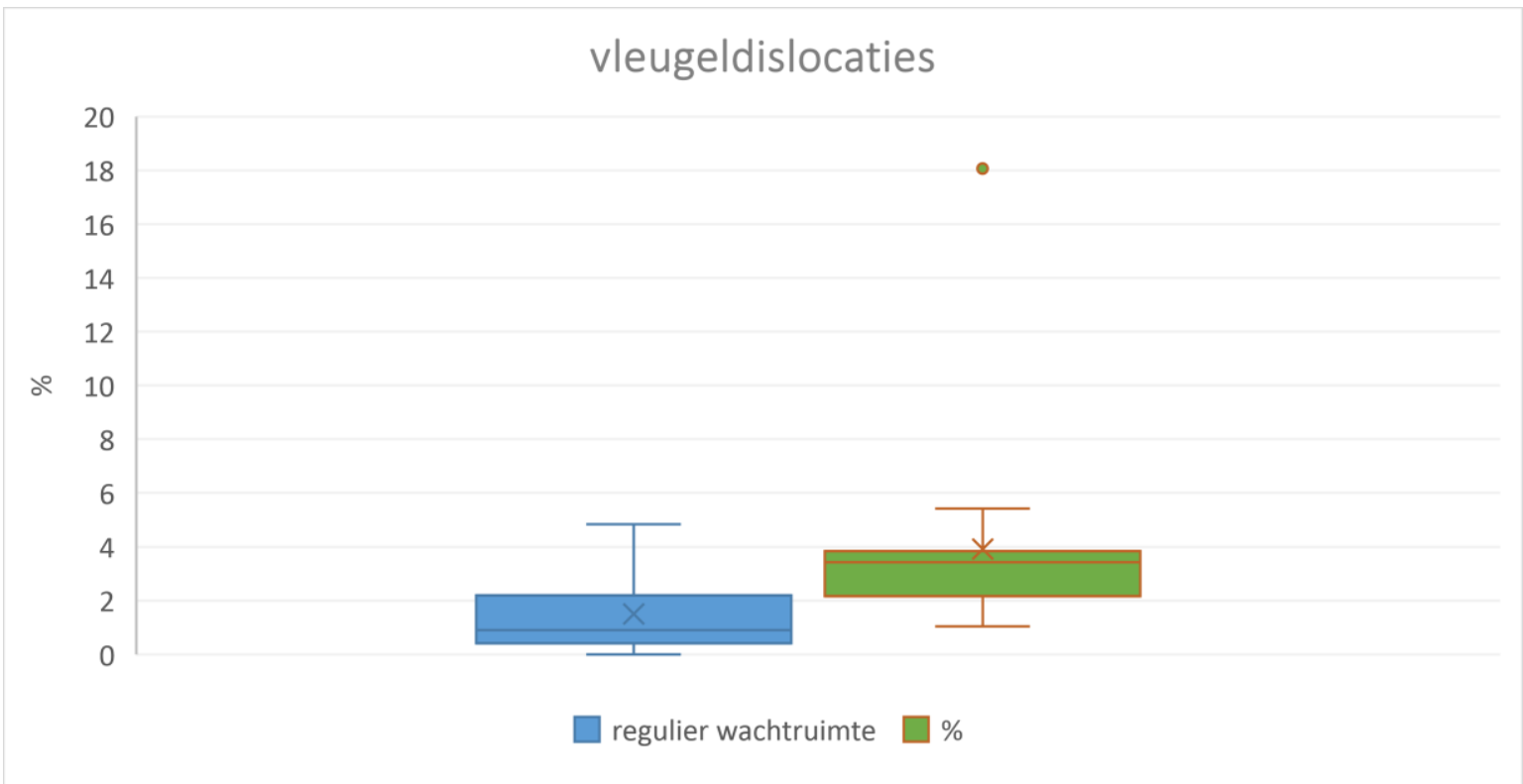

Figuur 4c: Boxplot waarin de mediaan (-), het gemiddelde $(x)$ en de laagste en hoogste waarde zijn voor vleugeldislocaties zijn weergegeven. De punt geeft een uitbijter weer.

De mediaan, de waarde waaronder $50 \%$ van de waarnemingen ligt, is voor zowel gemiddelde als voor grote bloedingen en ook voor vleugeldislocaties iets lager dan het rekenkundig gemiddelde. Dit betekend dat bij iets meer dan 50\% van de gescoorde koppels het \% vleugelbloedingen of vleugeldislocaties lager is dan het rekenkundig gemiddelde.

\subsubsection{Vang- en laadletsel per vangmethode}

In dit onderzoek zijn 3 verschillende methode van vangen toegepast: 1) het handmatig vangen van de kuikens uit de stal door een vangploeg $(n=28), 2)$ het vangen van de kuikens uit de stal met behulp van een vangmachine $(n=2)$ en 3 ) handmatig laden van containers vanuit Patio systeem.

Het percentage letsel bij de handmatig gevangen kuikens is het gemiddelde van 28 koppels verdeeld over 4 slachterijen. Het percentage letsel bij de kuikens gevangen met een vangmachine is het gemiddelde van 2 koppels afkomstig van 1 bedrijf en geslacht bij 1 slachterij. Het percentage letsel bij 
de kuikens uit een Patio-systeem is het gemiddelde van 2 koppels van 2 bedrijven geslacht bij 1 slachterij.

Bij de 2 koppels gevangen met de vangmachine valt het op dat het percentage vleugelbloedingen (middel + groot) beduidend hoger is dan bij de handmatig gevangen koppels. Daarnaast lijkt het erop dat bij de koppels gevangen met de vangmachine meer dislocaties van vleugels optreden.

Ook bij de koppels uit het patio systeem werden beduidend meer vleugelbloedingen gezien dan bij de handmatig gevangen koppels. Vanwege het geringe aantal koppels dat is gevangen met een vangmachine of is geladen uit een patio systeem is een statistische vergelijking tussen de vangmethoden niet mogelijk.

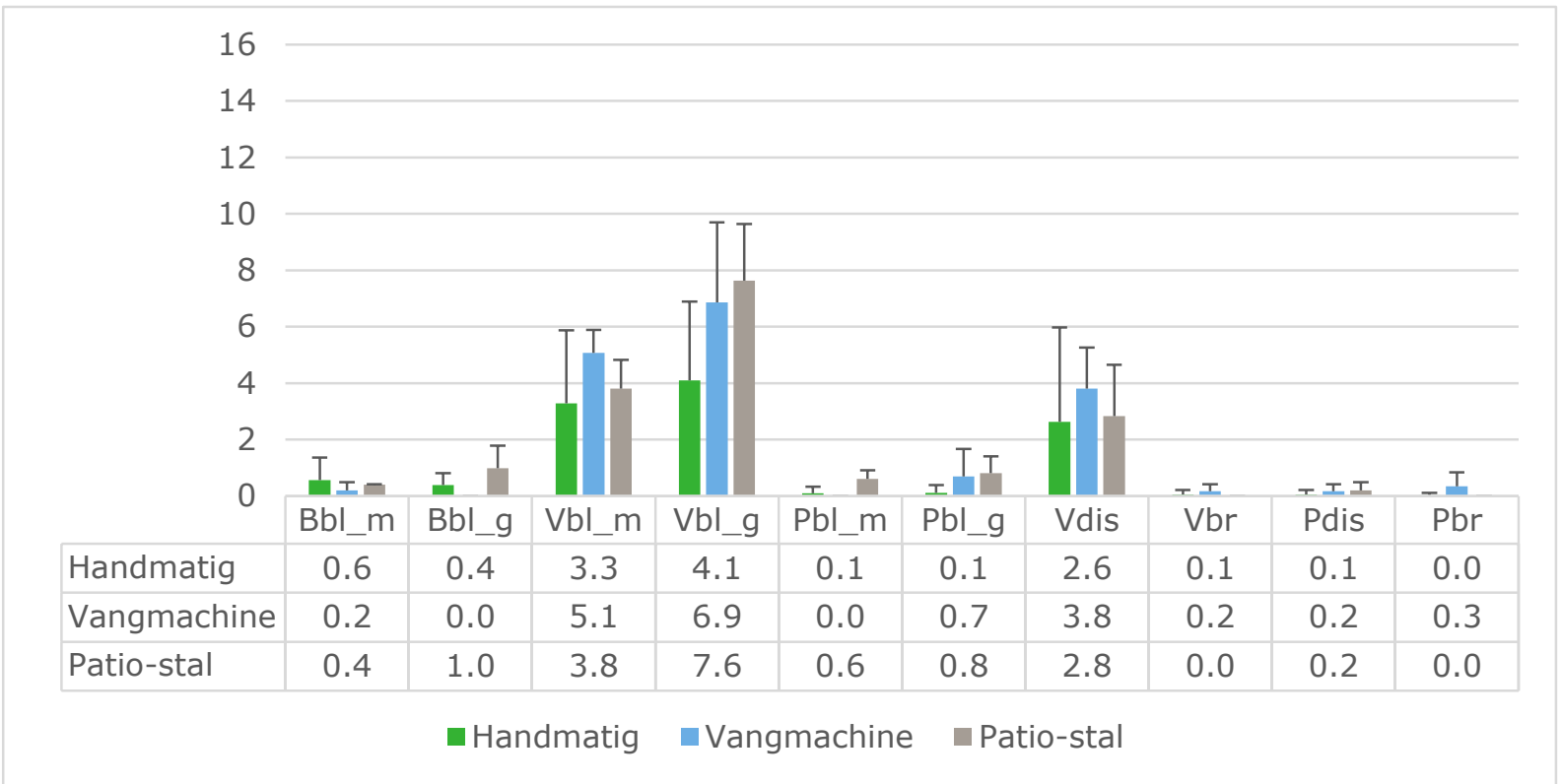

Figuur 5: Gemiddeld percentage bloedingen $(0,5-1 \mathrm{~cm}$ en $>1 \mathrm{~cm})$ aan de borst, de vleugels en de poten, dislocaties en breuken van vleugels én dislocaties en breuken van poten na vangen en laden bij handmatig gevangen kuikens, kuikens gevangen met een vangmachine en kuikens afkomstig uit een patio-stal.

\subsubsection{Vang- en laadletsel per bestemming}

Ten opzichte van slachterij A, C en D wijkt slachterij B af in de hoeveelheid kuikens per container (Tabel 4). Het aantal kuikens per lade op slachterijen A,C en D was ongeveer gelijk, respectievelijk 33, 33 en 31 gemiddeld. Bij slachterij B was dit aantal aanzienlijk hoger, gemiddeld 41 dieren per lade. Het gemiddeld slachtgewicht van de kuikens op slachterij B was 2054 gram en daarmee circa 500 gram lager dan het gemiddelde van de overige koppels.

Tabel 5: gemiddeld aantal kuikens per container bij de verschillende slachterijen.

\begin{tabular}{llll}
\hline Slachterij & $\begin{array}{l}\text { Gemiddeld aantal } \\
\text { kuikens/container }\end{array}$ & Standaarddeviatie & Aantal laden/container \\
\hline A & 266,4 & 16,8 & 8 \\
B & 415,3 & 84,2 & 10 \\
C & 265,5 & 17,1 & 10 \\
D & 249,0 & 8,2 & 8 \\
\hline
\end{tabular}

Het percentage letsel waargenomen in de wachtruimte op slachterij A t/m D (Figuur 6) is het gemiddelde van respectievelijk 18, 4, 4 en 6 koppels. Een vergelijking van letsel gescoord in de wachtruimte tussen de verschillende slachtlocaties is niet goed te maken omdat de waarnemingen sterk verstrengeld zijn met het type kuiken; koppels trager groeiende kuikens zijn op 1 slachterij beoordeeld en reguliere koppels zijn op alle 4 de slachterijen beoordeeld. Ook zijn de verdelingen van het aantal koppels, aantal dieren in de containers en de vangmethode niet evenredig over de verschillende slachterijen. 


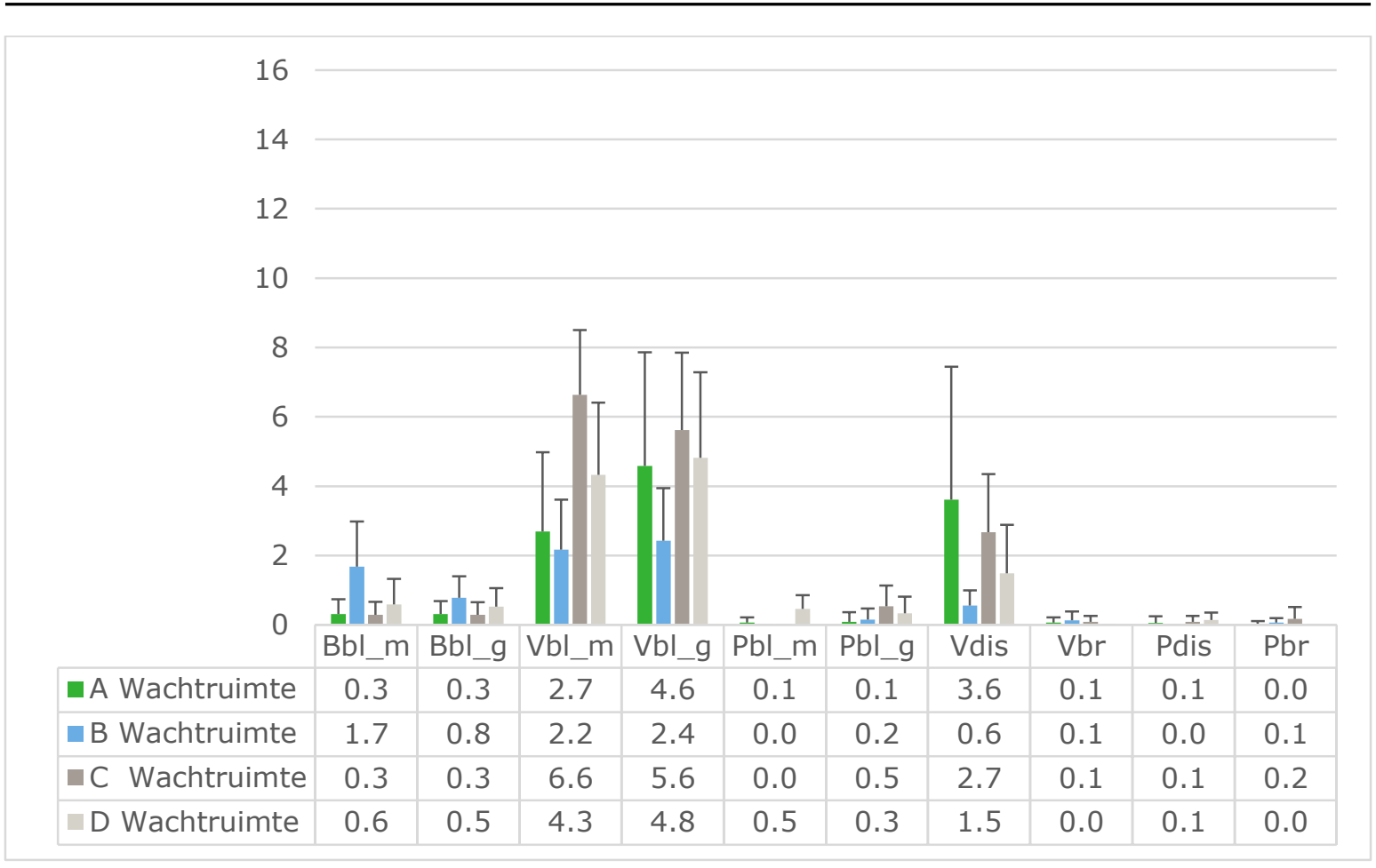

Figuur 6: Gemiddelde percentage bloedingen $(0,5-1 \mathrm{~cm}$ en $>1 \mathrm{~cm})$ aan de borst, de vleugels en de poten, dislocaties en breuken van vleugels én dislocaties en breuken van poten na vangen en laden per slachterij A t/m D.

Om toch een vergelijking tussen het letsel van koppels op de verschillende slachterijen te maken is een vergelijking van de resultaten van een specifieke slachterij ten opzichte van het totaal aantal koppels gemaakt.

Bij de koppels op slachterij B werden na aankomst op de slachterij in de wachtruimte gemiddeld 1,6\% meer borstbloedingen waargenomen ten opzichte van het gemiddelde van alle 32 koppels.

Daarentegen werden bij de koppels op slachterij B 3,3\% minder vleugelbloedingen waargenomen ten opzichte van het gemiddelde van alle koppels. Bij slachterij $\mathrm{C}$ werden $4,3 \%$ meer vleugelbloedingen waargenomen in de wachtruimte dan bij het gemiddelde van de 32 koppels.

De koppels op slachterij A hadden 0,9\% meer vleugel dislocaties dan het gemiddelde van alle 32 koppels (2,7\%). De koppels op slachterijen B en D hebben gemiddeld respectievelijk $2,1 \%$ en $1,2 \%$ minder dislocaties van een vleugel in de wachtruimte ten opzichte van het gemiddelde van de 32 koppels.

\subsubsection{Transportletsel}

Het percentage letsel waargenomen direct na vangen en laden van de containers en na transport in de wachtruimte is het gemiddelde van 4 koppels verdeeld over 3 bedrijven (Figuur 7). Er zijn 2 koppels geladen met een vangmachine en deze zijn afkomstig van 1 bedrijf. 


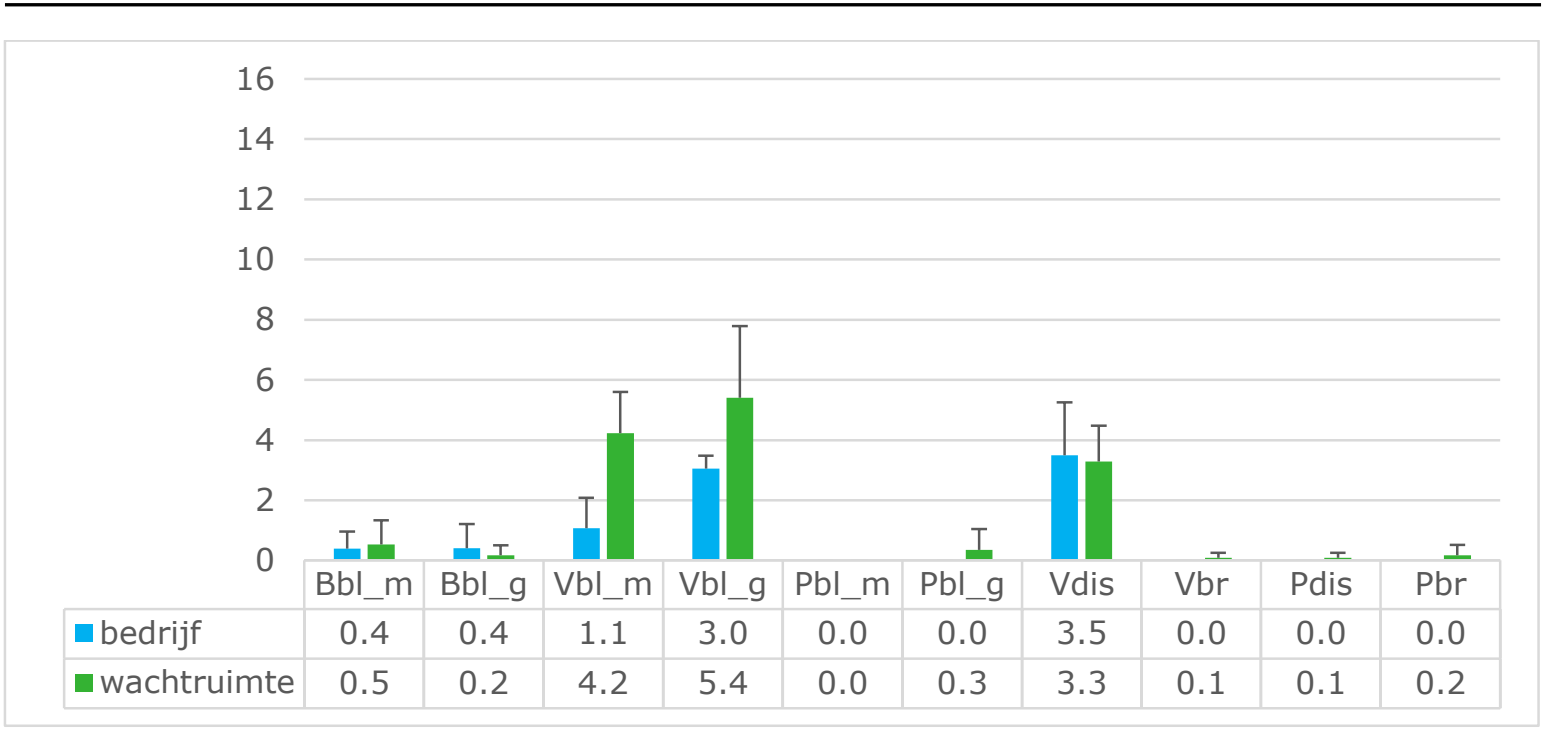

Figuur 7: Gemiddeld percentage kuikens met bloedingen $(0,5-1 \mathrm{~cm}$ en $>1 \mathrm{~cm})$ aan de borst, de vleugels en de poten, dislocaties en breuken van vleugels én dislocaties en breuken van poten na vangen en laden én na transport.

Voor transport is een dislocatie van de vleugel met gemiddeld 3,5\% het meest voorkomende letsel. Dit ligt $0,8 \%$ hoger dan het gemiddelde over de 32 koppels. Het aantal dislocaties neemt niet toe na transport. Na transport zijn bloedingen aan de vleugel het meest voorkomende letsel. De toename van de bloedingen aan de vleugels van 0,5 tot $1 \mathrm{~cm}$ of $>1 \mathrm{~cm}$ bedraagt respectievelijk gemiddeld 3,1 en $2,4 \%$. Of de bloedingen ontstaan zijn tijdens het transport of voor transport en na transport duidelijker zichtbaar worden is niet met zekerheid te zeggen. Bloedingen aan borst en poten zijn vergelijkbaar met de overige koppels en nemen tijdens transport niet toe.

Tijdens 3 van de 4 transporten waarbij letsel voor en na transport is beoordeeld zijn temperatuurmetingen uitgevoerd gedurende de hele transportduur (Figuur 8a-c). De buitentemperatuur is de opgegeven temperatuur van de verschillende weerberichten.

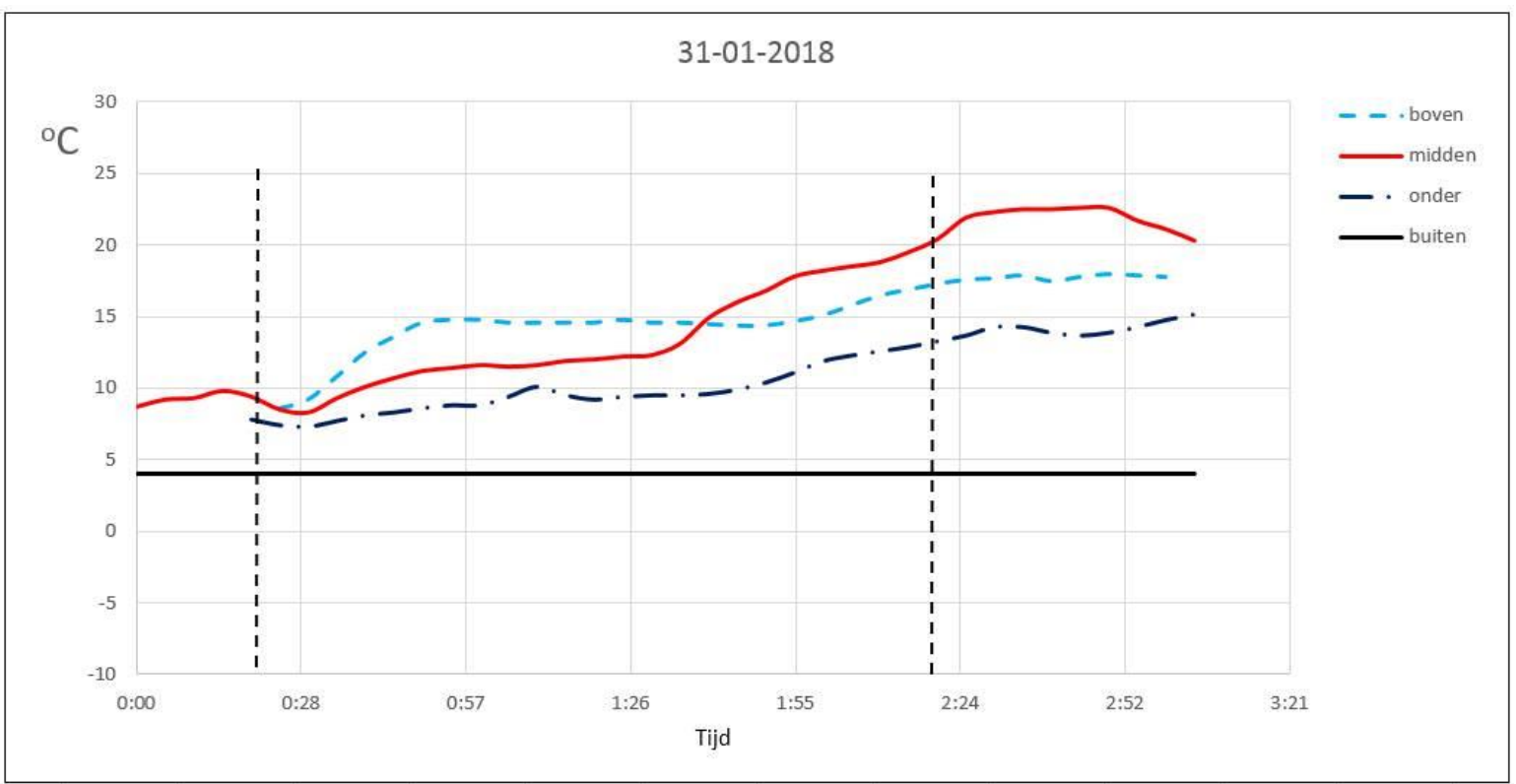

Figuur 8a: Temperatuurverloop tijdens transport van vleeskuikens gemeten op 3 locaties in de vrachtwagen. Periode tussen de verticale stippellijnen is de rij-periode. 


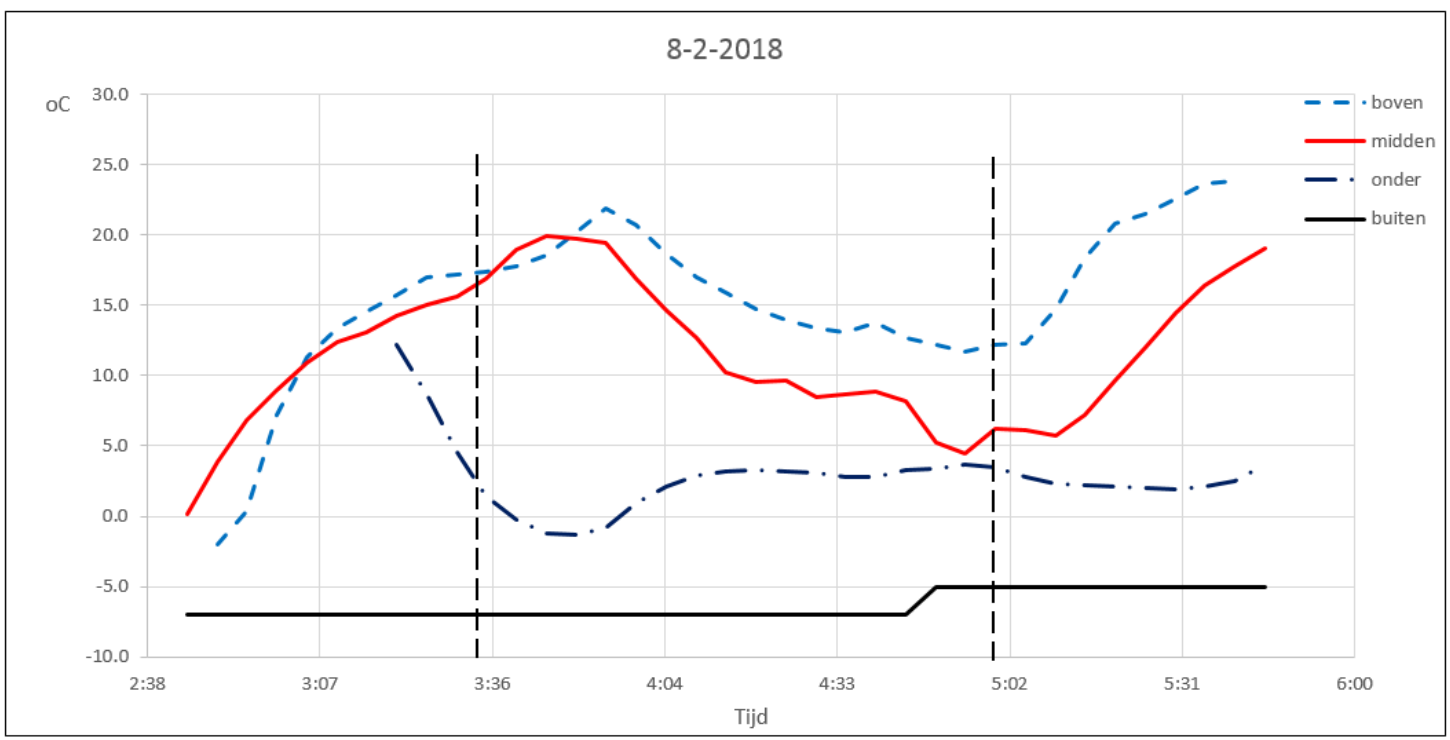

Figuur 8b: Temperatuurverloop tijdens transport van vleeskuikens gemeten op 3 locaties in de vrachtwagen. Periode tussen de verticale stippellijnen is de rijperiode.

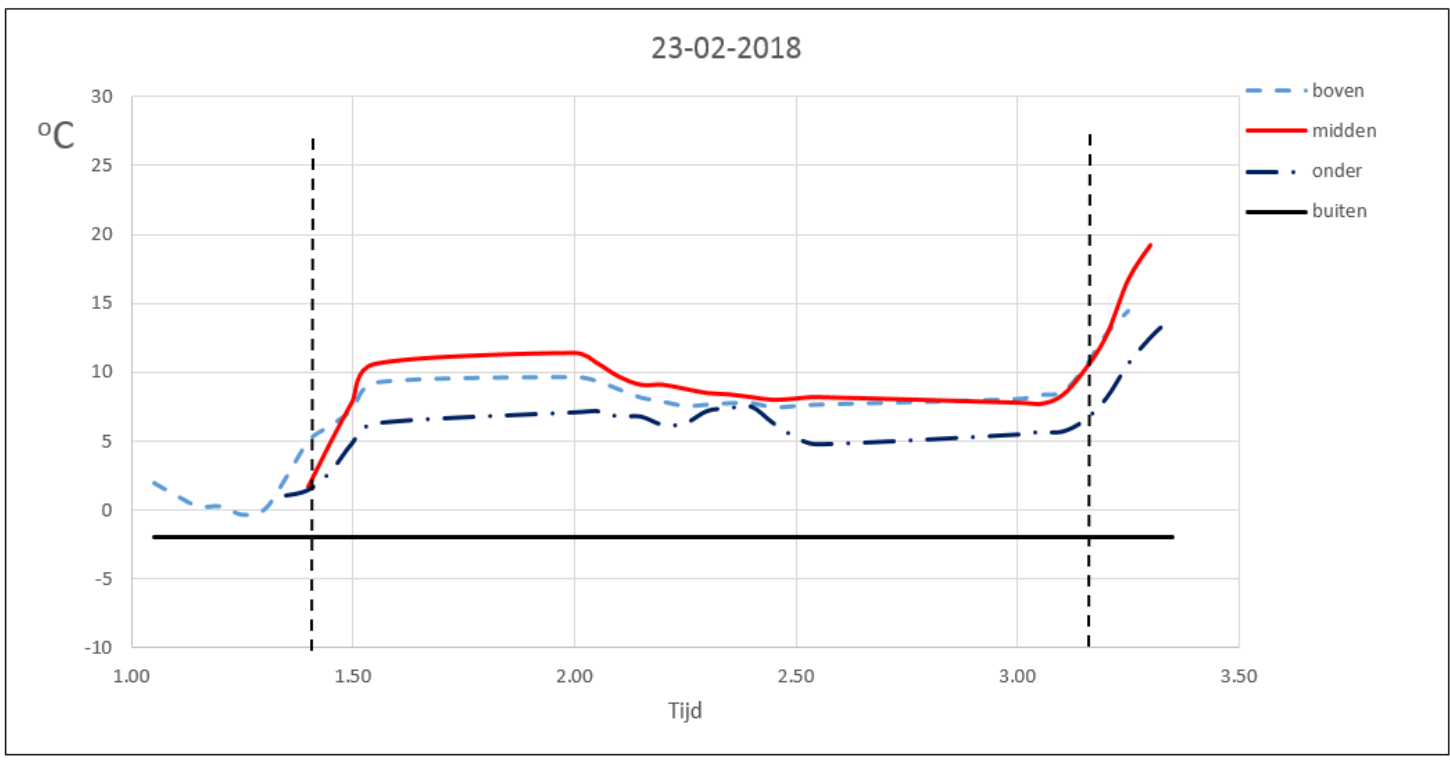

Figuur 8c: Temperatuurverloop tijdens transport van vleeskuikens gemeten op 3 locaties in de vrachtwagen. Periode tussen de verticale stippellijnen is de rijperiode.

Opvallend bij de 3 transporten is het grote verschil in temperatuur verloop tussen de transporten. Vooral tijdens het transport van 8 februari is de sterke temperatuurdaling bij de logger onder en achterin de vrachtwagen opvallend (Figuur 8b), de temperatuur is daar gedurende de gehele rijperiode tussen 0 en $5^{\circ} \mathrm{C}$. Ook de temperatuur in het midden van de vrachtwagen daalde flink gedurende het rijden van ca $20^{\circ} \mathrm{C}$ bij de start naar $5^{\circ} \mathrm{C}$ aan het eind van de rijperiode. Tijdens de andere 2 transporten (Figuur 8a en 8c) was het temperatuurverloop gelijkmatiger tijdens het transport. Wel opvallend is dat tijdens het transport op 31 januari de temperatuur midden in de vrachtwagen in de $2^{\mathrm{e}}$ helft van het transport oploopt van ca 12 naar bijna $20{ }^{\circ} \mathrm{C}$ terwijl de temperatuur boven en onder in deze vrachtwagen nagenoeg gelijk blijft. 


\subsection{Slachtschade}

Om een indruk te krijgen van het verschil in letsel wanneer dat wordt gescoord direct na aankomst in de wachtruimte en wanneer dat in de slachtlijn wordt gescoord (schade na slachten) zijn alle dieren zo kort mogelijk na de plukker nogmaals beoordeeld. Het percentage bloedingen, dislocaties en breuken zoals is weergegeven in Figuur 9 is een gemiddelde over alle 32 koppels en verdeeld over de 4 slachterijen.

De bloedingen aan de vleugels zijn bij 19 koppels beoordeeld door een medewerker van de slachterij en niet door een WLR medewerker. In enkele gevallen zijn er tussen de plukker en voor de beoordeling van schade, kuikens van de lijn verwijderd of van de lijn gevallen. Hierdoor is het aantal kuikens beoordeeld na slachten iets lager dan beoordeeld in de wachtruimte.

In de slachtlijn zijn $2 \%$ minder vleugelbloedingen waargenomen dan in de wachtruimte. Mogelijke redenen hiervoor zijn dat er kuikens met bloedingen van de lijn zijn gehaald voor dat deze zijn beoordeeld of dat in het geval van een open wond bloed is uitgewassen. Bloedingen aan borst en poten nemen toe in het slachtproces. Middelgrote bloedingen aan poten nemen toe met $1,3 \%$ tot gemiddeld $1,4 \%$ en grote bloedingen nemen toe met $2,9 \%$ tot een gemiddelde van $3,1 \%$.

Dislocaties van vleugels nemen toe met $5 \%$ tot een gemiddelde van $7,9 \%$ en zijn hiermee het meest voorkomende letsel of schade aan de kuikens na slachten. De dislocaties zijn voor het slachten in vrijwel alle gevallen gesloten terwijl na het slachten de dislocatie in 7 van de 8 gevallen gepaard gaat met een open wond. Vleugelbreuken nemen toe tot in totaal $1,1 \%$ van de kuikens, hiervan is het overgrote deel ontstaan in het slachtproces.

Dislocaties en breuken van poten nemen niet toe in het slachtproces.

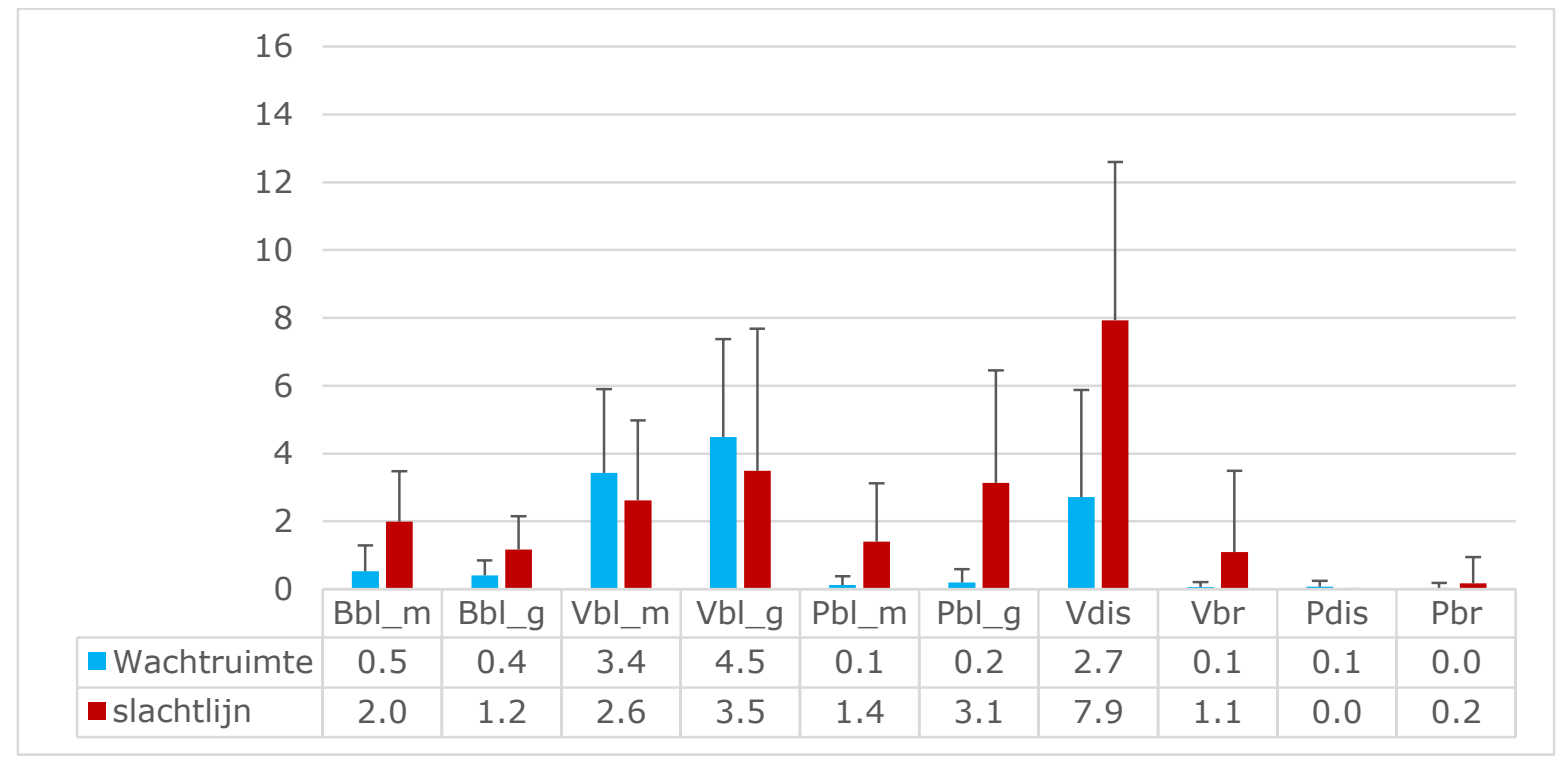

Figuur 9: Gemiddeld percentage kuikens met bloedingen $(0,5-1 \mathrm{~cm}$ en $>1 \mathrm{~cm})$ aan de borst, de vleugels en de poten, dislocaties en breuken van vleugels én dislocaties en breuken van poten na vangen en laden én na slachten.

\subsubsection{Reguliere versus trager groeiende kuikens}

Het percentage letsels bij de reguliere kuikens is het gemiddelde van 16 koppels verdeeld over 4 slachterijen (Figuur 10) en het percentage letsels bij de trager groeiende kuikens is het gemiddelde van 16 koppels geslacht bij 1 slachterij (zie Figuur 11). Bij de slachterij waar de trager groeiende koppels zijn geslacht zijn 2 van de 16 reguliere koppels geslacht. Door deze scheve verdeling van koppels over de slachterijen en de verstrengeling met verschillende factoren zoals vangmethode, transportduur, verdovingsmethode, is er geen statistische vergelijking te maken tussen regulier versus traag groeiend wat betreft slachtschade. 
Bij zowel reguliere koppels als bij de trager groeiende koppels neemt vooral het aandeel vleugeldislocaties sterk toe door het slachtproces. Bij reguliere koppels neemt het percentage vleugeldislocaties toe van $1,5 \%$ voor slachten tot $5,6 \%$ na slachten, bij trager groeiende kuikens neemt het aandeel vleugeldislocaties toe van 3,9\% vóór slachten tot $10,3 \%$ na slachten.

Kijkend naar het verschil tussen geslachte reguliere koppels $(n=2)$ en de trager groeiende koppels $(n=16)$ bij dezelfde slachterij dan lijkt het verschil tussen reguliere en trager groeiende koppels niet substantieel af te wijken van het gemiddelde van alle reguliere koppels.

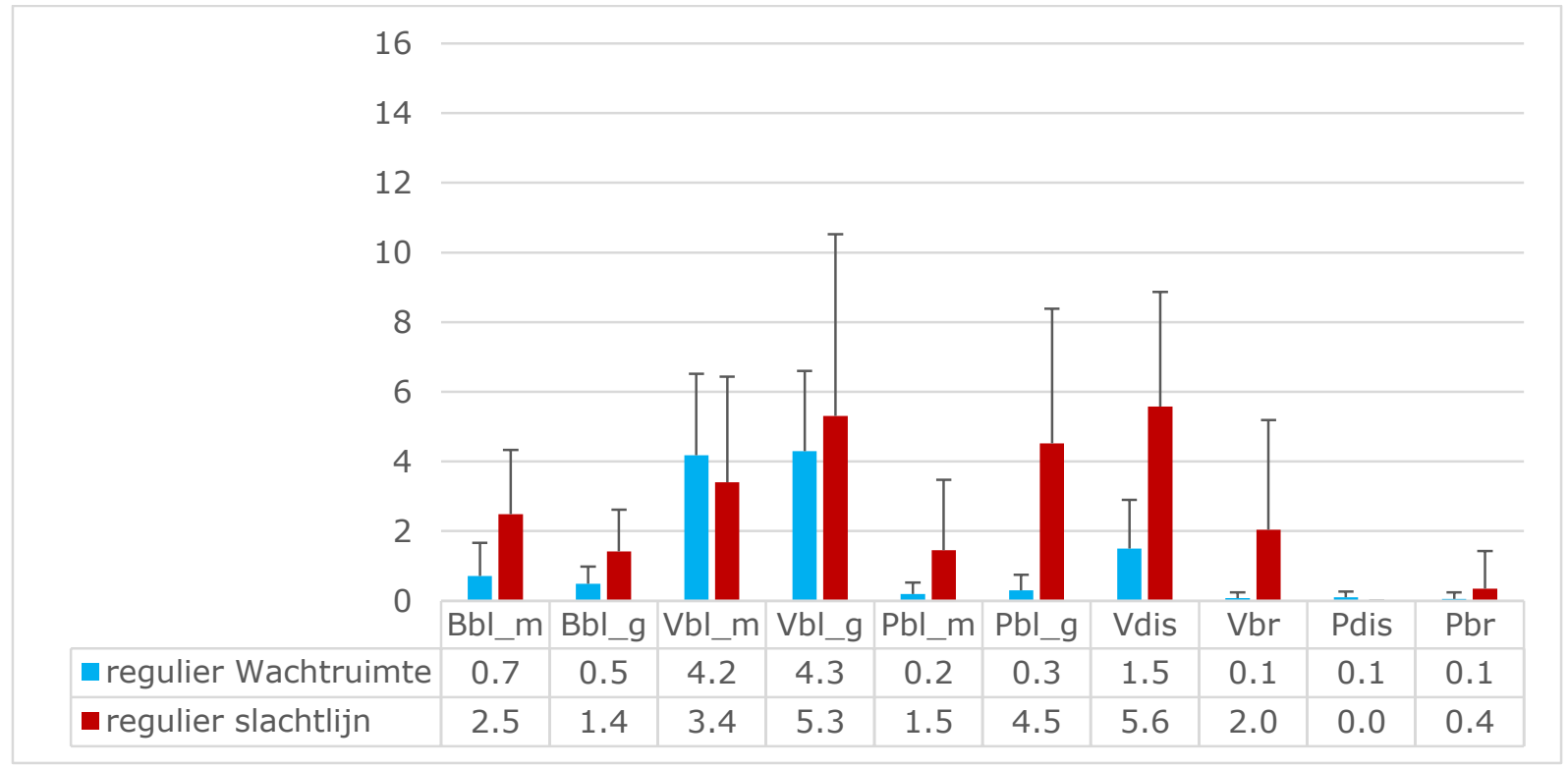

Figuur 10: Gemiddeld percentage reguliere kuikens met bloedingen $(0,5-1 \mathrm{~cm}$ en $>1 \mathrm{~cm})$ aan de borst, de vleugels en de poten, dislocaties en breuken van vleugels én dislocaties en breuken van poten na vangen en laden én na slachten.

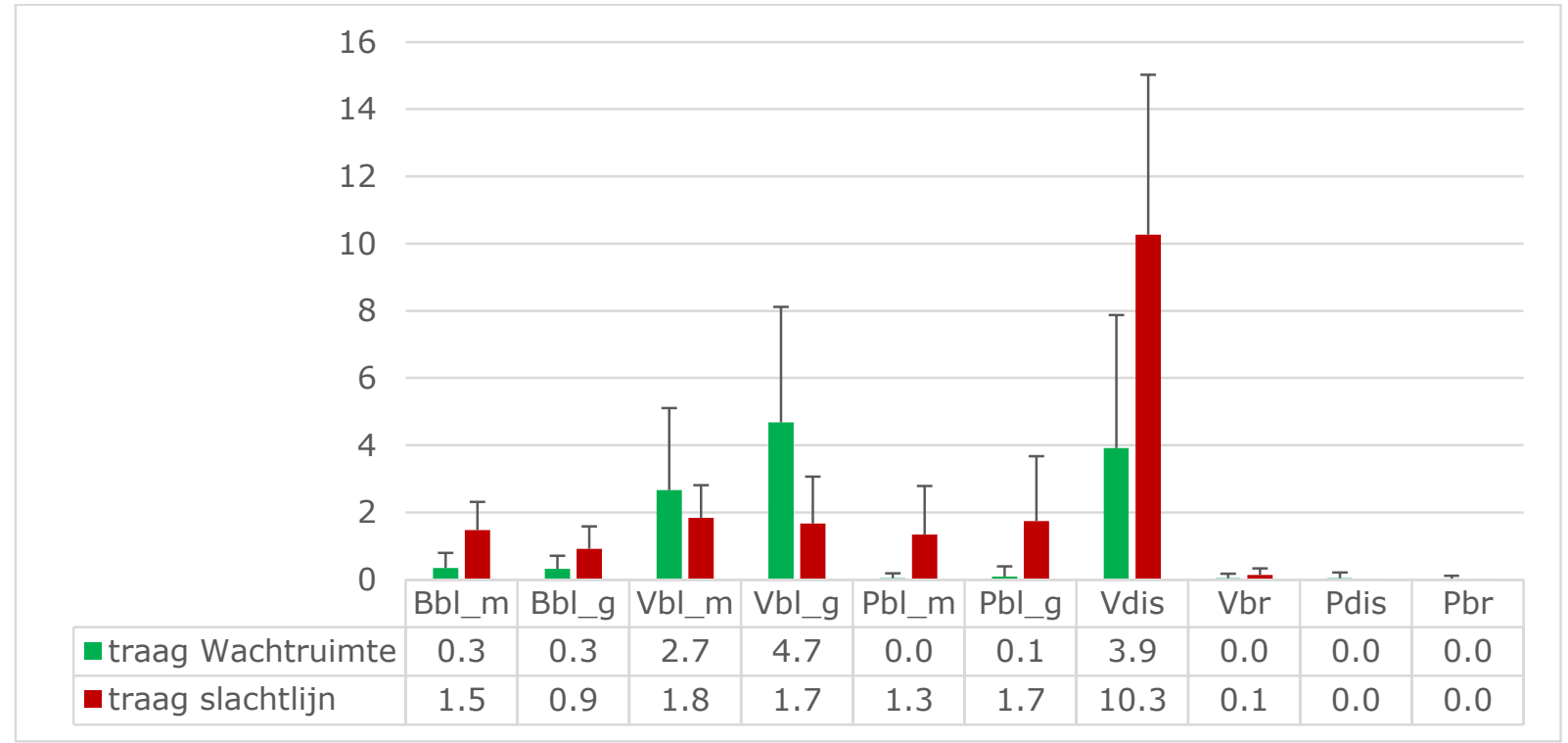

Figuur 11: Gemiddeld percentage trager groeiende kuikens met bloedingen $(0,5-1 \mathrm{~cm}$ en $>1 \mathrm{~cm})$ aan de borst, de vleugels en de poten, dislocaties en breuken van vleugels én dislocaties en breuken van poten na vangen en laden én na slachten.

\subsubsection{Welzijnsstatus van de subset van koppels}

In Tabel 6 worden een aantal algemene kenmerken weergegeven van de koppels die met de aangepaste welzijnsmonitor in de stal zijn beoordeeld. De tijd nodig voor een beoordeling van de 
koppels varieerde tussen 2,5 uur en 4,5 uur, waarbij de waarnemers bij koppels trager groeiende kuikens over het algemeen wat langer bezig waren met de metingen dan bij de reguliere koppels (mogelijk door de grotere beweeglijkheid van de dieren dan in de reguliere koppels). Dit is inclusief de tijd nodig voor het bevragen van de vleeskuikenhouder.

Tabel 6: Algemene bedrijfskenmerken van de koppels beoordeeld met de aangepaste welzijnsmonitor.

\begin{tabular}{|c|c|c|c|c|c|c|}
\hline & & \multicolumn{3}{|l|}{ Regulier } & \multicolumn{2}{|l|}{$\begin{array}{l}\text { Trager } \\
\text { groeiend }\end{array}$} \\
\hline & & aantal & & & aantal & \\
\hline Aantal bedrijven & & 6 & & & 5 & \\
\hline Aantal koppels & & 9 & & & 8 & \\
\hline \multicolumn{7}{|l|}{ Ras } \\
\hline Ross 308 & & 6 & & & & \\
\hline Cobb 500 SF & & 3 & & & & \\
\hline Hubbard JA757 & & & & & 8 & \\
\hline \multicolumn{7}{|l|}{ Strooiseltype } \\
\hline Gemalen stro & & & & & 3 & \\
\hline Turf & & 4 & & & & \\
\hline Houtvezel & & 1 & & & 3 & \\
\hline Houtkrullen & & 4 & & & 2 & \\
\hline & minimaal & gemiddeld & maximaal & minimaal & gemiddeld & maximaal \\
\hline Aantal dieren bij opzet & 15030 & 27103 & 35500 & 6030 & 22106 & 28000 \\
\hline Leeftijd bij bezoek & 33 & 38.8 & 42 & 48 & 49.6 & 50 \\
\hline Leeftijd ouderdieren & 30 & $57.5 *$ & 97 & 28 & 42.4 & 64 \\
\hline
\end{tabular}

*) gebaseerd op 8 koppels, koppel met gemengde leeftijd ouderdieren $(30,33,41 \mathrm{wk})$ achterwege gelaten.

In Bijlage 3 wordt een overzicht gegeven van de scores voor de verschillende welzijnsaspecten en vang- en laadschade voor deze subset van 17 koppels. Voor nagenoeg alle gemeten indicatoren scoren de koppels trager groeiende kuikens gemiddeld beter, behalve voor het percentage vermagerde kuikens. In Bijlage 3 staat ook het letsel voor slachten en de schade na slachten weergegeven voor de subset koppels gemeten met de welzijnsmonitor. Hieruit blijkt dat de verschillen tussen regulier en trager groeiend die werden gezien voor het totale aantal koppels ook te zien zijn in de subset koppels, dus we beschouwen de subset koppels als representatief voor het geheel.

Figuur 12 geeft de score weer voor de verschillende welzijnsaspecten zoals berekend met behulp van het Welfare Quality ${ }^{\circledR}$ protocol, evenals de totaalscore voor de diverse welzijnsaspecten. Een hogere score betekent een beter welzijn (lagere prevalentie welzijnsproblemen), dit geldt dus zowel voor de afzonderlijke metingen als de totaalscore. Uit de figuur blijkt dat er variatie is in de totale welzijnsscore binnen zowel de koppels trager groeiende kuikens als de koppels reguliere vleeskuikens, dit betekent dat het zinnig is om te kijken naar de correlatie tussen de welzijnsscores binnen een systeem en het gemeten letsel. De gemiddelde totaalscore voor de koppels trager groeiende kuikens was hoger dan voor de reguliere kuikens (915.0 voor trager groeiende kuikens en 614.6 voor reguliere kuikens), maar de score van één koppel reguliere kuikens viel binnen de range van scores voor de koppels trager groeiende kuikens.

De volgende bijzonderheden met betrekking tot gezondheid en gedrag van het koppel werden genoteerd door de waarnemer (eigen waarneming plus bevraging vleeskuikenhouder): koppel 1 goede gezondheid volgens vleeskuikenhouder, maar de beoordelaar gaf aan dat de algemene indruk van het koppel 'matig' was; koppel 7 is het enige koppel waar antibiotica zijn toegepast; koppels 9, 10 en 14 werden als 'zeer zenuwachtig' beoordeeld, en bij koppel 17 en 18 werd kreupelheid gemeld door de vleeskuikenhouder. Voor de overige koppels werden geen bijzonderheden genoteerd. 


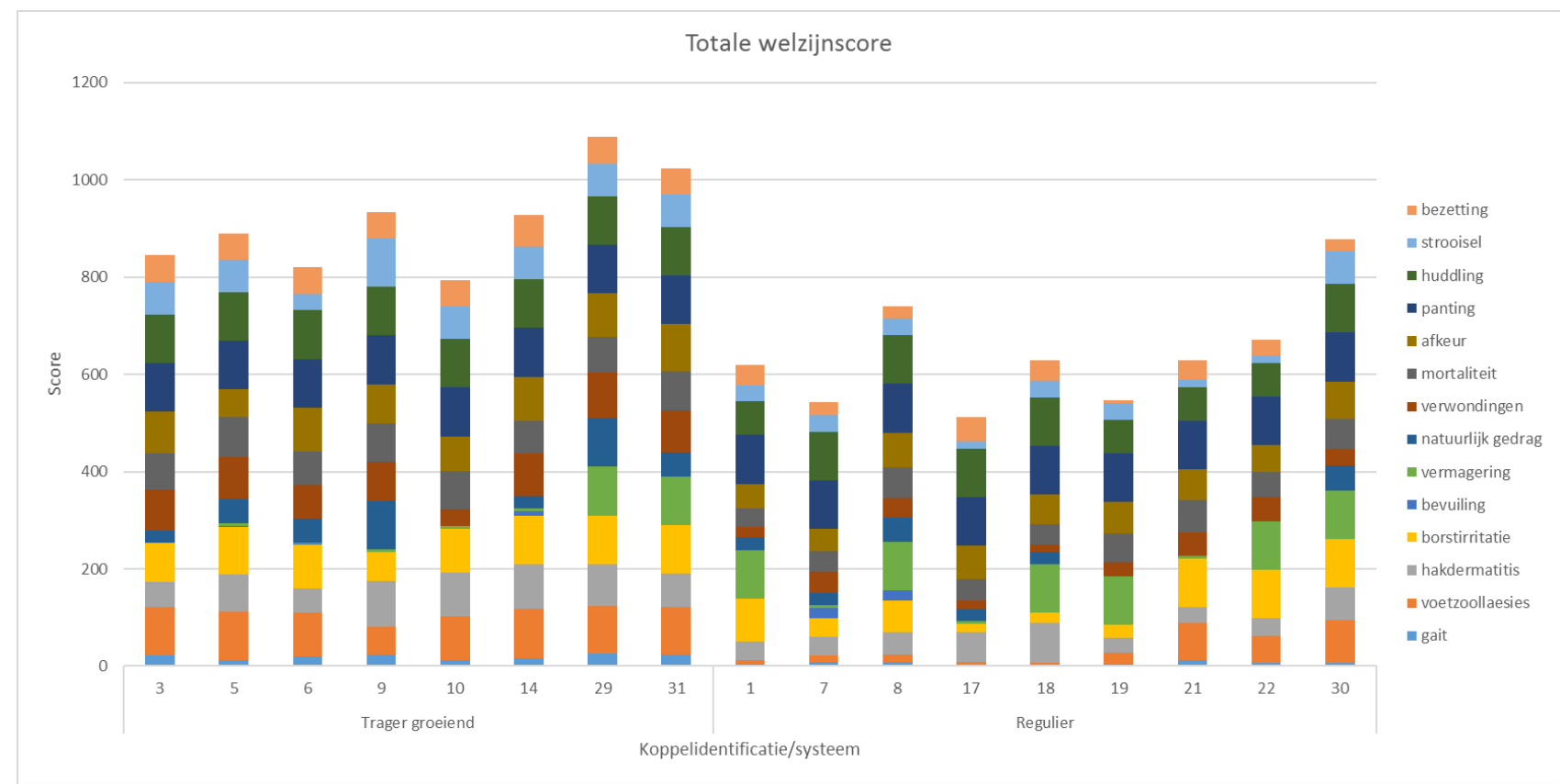

Figuur 12: Totale welzijnsscore voor de koppels beoordeeld met de aangepaste welzijnsmonitor, opgebouwd uit de afzonderlijke scores voor de welzijns- en gezondheidsindicatoren. Des te hoger de score, des te beter. In de legenda staan de verschillende welzijnsindicatoren die voor deze koppels zijn gescoord. Voor een toelichting verwijzen we naar Welfare Quality (2009). 'Gait' is een score voor de kwaliteit van de locomotie van de kuikens (gait score). De overige indicatoren spreken voor zich.

Tabel 6 geeft de correlaties weer tussen de kenmerken voor de koppels trager groeiende kuikens, en Tabel 7 laat hetzelfde zien voor de koppels reguliere vleeskuikens. Uit beide tabellen blijkt dat er geen correlatie is tussen de totale welzijnsscore en letsel of DOA's. Uit Tabel 6 blijkt dat er een positieve correlatie is tussen de score voor voetzoollaesies en het percentage DOA (betere voetzolen, hoger \% DOA), een positieve correlatie tussen de score voor mortaliteit op het bedrijf en het percentage DOA (lagere mortaliteit op primaire bedrijf, meer DOA), en een negatieve correlatie tussen de mortaliteitsscore en \% vleugeldislocaties (en dislocatie+breuk; vanwege het geringe percentage breuken is deze correlatie gelijk aan die van de dislocaties voor de trager groeiende koppels). Dit houdt dus in dat bij meer uitval op het primaire bedrijf, er minder dislocaties voorkwamen.

Tabel 6: Correlatie matrix voor correlaties tussen de welzijnsscores en vang- en laadletsel voor koppels trager groeiende vleeskuikens $(N=8)$. Vanwege het geringe aantal koppels moeten de data als indicatief beschouwd worden. Dit geldt ook voor de significanties $(*=P<0.05)$. Correlaties $>0.3$ of $<-0.3$ zijn vetgedrukt. Correlaties zijn berekend tussen de scores berekend per welzijnsindicator en het letsel of DOA\%, waarbij we nadrukkelijk vermelden dat een hogere score een betere score inhoudt.

\begin{tabular}{lllll}
\hline & $\begin{array}{l}\text { \% vleugel } \\
\text { disclocaties }\end{array}$ & $\begin{array}{l}\text { \% bloedingen } \\
\text { totaal }\end{array}$ & $\begin{array}{l}\text { \% vleugel } \\
\text { dislocaties+breuk }\end{array}$ & \% DOA \\
\hline Score vzl & -0.268 & 0.244 & -0.268 & $\mathbf{0 . 4 3 6}$ \\
Score locomotie & -0.252 & -0.120 & -0.252 & -0.101 \\
Score mortaliteit & $\mathbf{- 0 . 6 1 1 *}$ & 0.252 & $\mathbf{- 0 . 6 1 1 *}$ & $\mathbf{0 . 6 1 7} *$ \\
Tot welzijnsscore & -0.143 & 0.262 & -0.143 & 0.262 \\
\hline
\end{tabular}

Uit Tabel 7, reguliere koppels, blijkt dat er een positieve correlatie is tussen de voetzoollaesiescore en het percentage vleugeldislocaties (met en zonder breuk) en het percentage DOA, dus bij minder voetzoollaesies zijn er meer vleugeldislocaties (of dislocaties en breuken) en meer DOA. Ook koppels met een betere locomotie hebben meer DOA's. Een lagere mortaliteit is gerelateerd aan meer vleugeldislocaties, meer bloedingen, en meer DOA's. als laatste is een hogere totale welzijnsscore negatief gerelateerd aan DOA's, dus als alle welzijns- en gezondheidsaspecten worden meegenomen betekent een betere welzijnsscore dat er minder DOA's zijn waargenomen. 
Tabel 7: Correlatie matrix voor correlaties tussen welzijnsscore en vang- en laadletsel voor koppels reguliere vleeskuikens $(N=9)$. Vanwege het geringe aantal koppels moeten de data als indicatief beschouwd worden. Dit geldt ook voor de significanties $(*=P<0.05)$. Correlaties $>0.3$ of $<-0.3$ zijn vetgedrukt. Correlaties zijn berekend tussen de scores berekend per welzijnsindicator en het letsel of DOA\%, waarbij we nadrukkelijk vermelden dat een hogere score een betere score inhoudt.

\begin{tabular}{lllll}
\hline & $\begin{array}{l}\% \text { vleugel } \\
\text { disclocaties }\end{array}$ & $\begin{array}{l}\text { \% bloedingen } \\
\text { totaal }\end{array}$ & $\begin{array}{l}\text { \% vleugel } \\
\text { dislocaties+breuk }\end{array}$ & \% DOA \\
\hline Score vzl & $\mathbf{0 . 5 0 0 *}$ & 0.150 & $\mathbf{0 . 4 1 7}$ & $\mathbf{0 . 4 2 0}$ \\
Score locomotie & -0.050 & 0.167 & -0.100 & $\mathbf{0 . 6 3 0 *}$ \\
Score mortaliteit & $\mathbf{0 . 4 5 0}$ & $\mathbf{0 . 3 5 0}$ & 0.283 & $\mathbf{0 . 6 0 5 *}$ \\
Tot welzijnsscore & 0.233 & -0.067 & 0.283 & $\mathbf{- 0 . 3 1 9}$ \\
\hline
\end{tabular}

Naast bovengenoemde correlaties is ook nog de Spearman Rank Correlatie berekend tussen de locomotiescore en \% spreidzit gescoord in de wachtruimte voor de koppels reguliere kuikens. Voor reguliere vleeskuikens werd een $\mathrm{R}^{2}=0.471, \mathrm{P}<0.05$ gevonden (betere locomotie resulteert in meer spreidzit). Echter ook hiervoor geldt dat we voorzichtig moeten zijn met de interpretatie, omdat spreidzit niet in ieder koppel is waargenomen (en er dus enkele nullen in de data voorkomen). De correlatie is niet berekend voor de koppels trager groeiende kuikens, omdat daar nog meer koppels zonder spreidzit werden waargenomen.

In Bijlage 4 staat grafisch weergegeven de relatie tussen de voetzoollaesiescore en vang- en laadletsel, in Bijlage 5 tussen de locomotie-score en vang- en laadletsel, in Bijlage 6 tussen de mortaliteitsscore en vang- en laadletsel en in Bijlage 7 tussen de totale welzijnsscore en vang- en laadletsel. 


\section{$5 \quad$ Discussie}

\section{$5.1 \quad$ Vang- en laadletsel}

Bij de beoordeling van de kuikens direct na aankomst op de slachterij is duidelijk geworden dat vleugelbloedingen en vleugeldislocaties het meest voorkomend letsel is bij vleeskuikens waargenomen direct na aankomst. Dit komt overeen met eerdere studies (Kittelsen et al., 2015b; Jacobs et al., 2017b). De observaties van kuikens direct na aankomst op de slachterij laten zien dat er grote verschillen zijn tussen aangevoerde koppels. Door de veelheid aan verschillende factoren en de relatief kleine steekproef kunnen er geen conclusies over het mogelijke effect van vangploeg of vangmethode op het percentage kuikens met vleugelletsel worden getrokken. Wel is duidelijk dat er verschillen zijn tussen reguliere kuikens en trager groeiende kuikens. Bij koppels reguliere kuikens werden meer vleugelbloedingen kleiner dan $1 \mathrm{~cm}$ gezien dan bij koppels trager groeiende kuikens (4,3\% vs. 2,7\% voor regulier vs. trager groeiend). Bloeidingen groter dan $1 \mathrm{~cm}$ kwamen juist vaker voor bij trager groeiende kuikens dan bij reguliere kuikens (4,7\% vs. 4,3\% voor trager groeiend vs. regulier). Als we focussen op de grotere bloedingen, dus $>1 \mathrm{~cm}$, dan blijkt dat bij zowel de reguliere als bij de trager groeiende koppels in $75 \%$ van de geobserveerde koppels meer dan $2 \%$ van de kuikens een vleugelbloeding groter dan $1 \mathrm{~cm}$ heeft bij aankomst op de slachterij. Bij de trager groeiende kuikens worden direct na aankomst op de slachterij significant meer vleugeldislocaties aangetroffen dan bij de reguliere kuikens (gem. 3,9\% vs. 1,5\%). Bij 70\% van de reguliere koppels ligt het percentage vleugeldislocaties onder de $2 \%$ terwijl bij de trager groeiende kuikens bij meer dan $75 \%$ van de koppels het percentage vleugeldislocaties boven de $2 \%$ ligt. Bij de trager groeiende kuikens ligt het percentage vleugeldislocaties bij 50\% van de koppels boven de 3,6\%.

Mede op basis van de observaties die zijn uitgevoerd op het primaire bedrijf in de stal en direct na vangen en laden, maar voor transport, en de bevindingen uit de literatuur (Nijdam et al., 2006; Jacobs, 2016) is de conclusie terecht dat vleugelbloedingen ( $5 \%$ van de dieren) en vleugeldislocaties (bij 2,9\% van de dieren) tijdens vangen en laden worden veroorzaakt. In het slachtproces neemt het aandeel vleugeldislocaties toe van 2,9\% naar 7,9\%. Doordat momenteel schade- en letselbeoordeling na het slachtproces plaatsvindt, is nader onderzoek nodig om beter onderscheid te kunnen maken wanneer letsel en schade ontstaat in de pluimveevleesketen. Er werden geen correlaties gevonden met het gewicht van de kuikens, in tegenstelling tot eerder onderzoek (De Jong et al., 2018; Langkabel et al., 2015). Ook werden er geen correlaties gevonden met de vangploeg of vangmethode. Mogelijk dat bij grotere aantallen koppels deze correlaties wel gevonden worden. Wel is duidelijk dat bij trager groeiende kuikens meer vleugelletsel optreedt door het vangen en laden. De grotere bewegelijkheid van de kuikens en de sterkere vleugels zijn hiervan waarschijnlijk de achterliggende oorzaak. Dit betekent dat verder bekeken zal moeten worden hoe vleugelletsel als gevolg van vangen bij koppels trager groeiende kuikens omlaag gebracht kan worden.

\subsection{Transport}

Bij 4 koppels is letsel van de dieren vastgesteld op het primaire bedrijf direct na vangen en laden van de containers en direct na aankomst op de slachterij. De enige toename in zichtbaar letsel na transport was het percentage vleugelbloedingen. Gezien de aard van de bloedingen en het feit dat dit het enige toegenomen letsel is tijdens transport lijkt het aannemelijk dat de oorsprong van deze bloedingen bij het vangen ligt. Bloedingen hebben enige tijd nodig om te ontwikkelen na het ontstaan van weefselschade en worden dan gedurende de transportduur zichtbaar. De transport duur en transport omstandigheden waren dusdanig dat er geen verschillen in mortaliteit zijn opgestreden zoals wel zijn aangetoond in eerder onderzoek (Vecerek 2006, Mitchel and Kettlewell 2009).

Tijdens 3 transporten waar ook de temperatuur op verschillende locaties in de vrachtwagen tussen de kuikens gemeten is, werd bevestigd dat het temperatuurverloop tussen transporten sterk verschilt. De 
grote temperatuurverschillen tussen transporten maar ook binnen 1 transportcombinatie laten zien dat onderzoek naar verbetering van klimaatcondities tijdens transport van belang is.

\subsection{Slachtproces}

In het slachtproces wordt het percentage vleugelbloedingen niet verhoogd, maar neemt het percentage gescoorde vleugelbloedingen zelfs licht af. De afname wordt waarschijnlijk veroorzaakt doordat in het slachtproces bij kuikens met dislocaties van de vleugels de huid stuk gaat en de bloeding wordt uitgewassen. Het scoren van grote bloedingen in de slachtlijn na plukken lijkt op basis van ons onderzoek dan ook een valide methode voor het vaststellen van vleugelbloedingen veroorzaakt door het vang- en laadproces.

Het slachtproces veroorzaakt een duidelijke toename van het percentage vleugeldislocaties (van 2,7\% naar 7,9\%). Dit komt overeen met eerder onderzoek (Langkabel et al., 2015; De Jong et al., 2018). In het onderzoek van Jacobs (2016) werd geen relevante toename in vleugelschade gezien door het slachtproces. Om vast te stellen of vleugeldislocaties zijn veroorzaakt door het vang- en laadproces is het nodig om het letsel in de wachtruimte van de slachterij te scoren. Bloedingen aan de poten door het vang- en laadproces kwamen zeer weinig $(0,2 \%)$ voor bij de geobserveerde koppels. Wel was er een duidelijke toename naar $3,1 \%$ bloedingen $>1 \mathrm{~cm}$ door het slachtproces te zien. Pootbloedingen scoren in relatie tot vang- en laadletsel lijkt dan ook niet erg relevant.

\subsection{Welzijnsmonitor vleeskuikens}

De resultaten van de beoordeelde koppels laten een flinke variatie in de totale welzijnsscore zien, zowel binnen de trager groeiende als binnen de reguliere koppels. Dit komt overeen met het beeld wat eerder is verkregen bij beoordeling van zowel trager groeiende als reguliere koppels vleeskuikens (De Jong et al., 2011; De Jong et al., 2015). Gemiddeld gezien was de welzijnsscore hoger (dus beter) voor koppels trager groeiende vleeskuikens dan voor koppels reguliere kuikens, wat eveneens overeenkomt met eerder uitgevoerd onderzoek (De Jong et al., 2011; De Jong et al., 2015). Wel was het zo dat de score van één regulier koppel binnen de range van trager groeiende koppels viel, wat aangeeft dat koppels trager groeiende kuikens niet per definitie beter scoren dan koppels reguliere kuikens. Trager groeiende koppels scoorden over het algemeen beter op alle kenmerken, behalve het percentage vermagerde kuikens. Dit komt ook overeen met eerder gevonden resultaten in koppels trager groeiende en reguliere vleeskuikens (De Jong et al., 2011; De Jong et al., 2014). De terugkoppeling met behulp van de benchmarkrapporten leek te voldoen aan de behoefte van vleeskuikenhouders om met een duidelijk visueel beeld de prestatie van hun koppel ten opzichte van het gemiddelde te zien. De benodigde tijd voor het uitvoeren van de aangepaste versie van de monitor was nog steeds aanzienlijk (minimaal 2,5 uur) en er lijken op dit moment, zonder automatisering, geen opties te zijn om de benodigde tijd voor de welzijnsbeoordeling van een koppel verder te verkorten (de Jong et al., 2016).

In dit project werd de welzijnsmonitor vleeskuikens toegepast om een indruk te verkrijgen of deze mogelijk geschikt kan zijn om de fitheid van een koppel voorafgaand aan het vangen, transport en slachten in beeld te krijgen. De fitheid van een koppel wordt verondersteld gecorreleerd te zijn met de mate waarin letsel optreedt tijdens het proces van vangen, laden en transport (Chauvin et al., 2011; Kittelsen et al., 2017). Jacobs et al. (2017c) vond dat koppels die werden geclassificeerd als niet fit voor transport (op basis van fysieke kenmerken zoals verwondingen, gait score, bevuiling, vermagering, etc.) een sterkere stressrespons vertoonden in respons op vangen en transport. Kittelsen et al. (2017) vonden dat het percentage DOA hoger was bij koppels die onder andere een hogere eerste weeks uitval hadden en meer voetzoollaesies hadden. In dit onderzoek hebben we daarom ook gekeken naar mogelijke correlaties tussen de totale welzijnsscore (bepaald met de welzijnsmonitor) en scores voor enkele afzonderlijke welzijnskenmerken met het percentage DOA, vleugelletsel en totale aantal bloedingen. Hierbij moet nadrukkelijk worden opgemerkt dat we in dit project een zeer kleine steekproef hebben gebruikt, en dat er altijd verder onderzoek uitgevoerd zal moeten worden om te bepalen of de gevonden correlaties daadwerkelijk bestaan. Correlaties zijn 
apart bepaald binnen de reguliere en trager groeiende koppels. Over het algemeen waren correlaties hoger wanneer deze werden bepaald met de afzonderlijke welzijnsscores (voetzoollaesies, locomotie en mortaliteit) dan met de totale welzijnsscore, waarschijnlijk omdat de totale welzijnsscore meer kenmerken bevat die niet gerelateerd zijn aan letsel in het proces van vangen tot slachten. Wanneer we dan naar de afzonderlijke welzijnsscores kijken, dan zagen we dat de correlaties tussen de voetzoollaesiescore en de mortaliteitsscore, en het gevonden letsel en DOA's aanleiding geven voor verder onderzoek. Zo was een betere score voor voetzoollaesies en mortaliteit gerelateerd aan meer letsel door vangen en transport. Mogelijk dat deze kuikens beweeglijker zijn, waardoor het risico op letsel groter is; dit moet echter wel verder onderzocht worden. Verder was een lagere mortaliteit gerelateerd aan meer DOA's, wat tegengesteld was aan de bevindingen van Kittelsen et al. (2017). Het is onduidelijk wat daarvoor de verklaring is, ook dit vraagt verder onderzoek.

\subsection{Conclusies}

$\mathrm{Na}$ beoordeling van de kuikens direct na aankomst op de slachterij is duidelijk geworden dat vleugelbloedingen en vleugeldislocaties het meest voorkomend letsel is bij vleeskuikens. Gemiddeld gezien kwam vleugelletsel meer voor bij koppels trager groeiende dan bij koppels reguliere kuikens. Tussen individuele koppels was er echter grote variatie in percentage kuikens met vleugelletsel. Verder onderzoek naar het reduceren van vleuggelletsel en dan met name naar het voorkomen van vleugeldislocaties is aan te bevelen.

De welzijnsmonitor vleeskuikens geeft een overall beeld van het welzijn van een koppel. De totale welzijnsscore is niet gecorreleerd met letsel, de scores voor voetzoollaesies en mortaliteit lijken wel een relatie te hebben met letsel. De statistische verbanden zijn gebaseerd op een klein aantal koppels en moeten daarom met de nodige voorzichtigheid worden geïnterpreteerd. Het is daarom aan te bevelen om verder te onderzoeken of deze kenmerken van invloed zijn op het verwachte vang- en laadletsel van het koppel, en zo ja, hoe uitval als gevolg van transport en letsel in deze koppels teruggebracht kan worden. 


\section{Literatuur}

Bremmer, A. en Johnston, M. (1996). 'Poultry meat hygiene and Inspection.' W.B. Sounders company Ltd, England, blz. 57.

Delezie, E., 2006. Manual and mechanical catching and transport of broilers: Implications for welfare, physiology and product quality and ethical considerations. PhD Diss. Nr 721. K.U. Leuven, Leuven.

Delezie, E., Q. Swennen, J. Buyse, and E. Decuypere. 2007. The effect of feed withdrawal and crating density in transit on metabolism and meat quality of broilers at slaughter weight. Poult. Sci. 86(7):1414-1423.

Chauvin, C., S. Hillion, L. Balaine, V. Michel, J. Peraste, I. Petetin, C. Lupo, and S. Le Bouquin. 2011. Factors associated with mortality of broilers during transport to slaughterhouse. Animal 5:287-293. doi $10.1017 / \mathrm{s} 1751731110001916$.

Jong, I.C. de; Perez Moya, T.; Gunnink, H.; Heuvel, J. van den; Hindle, V.A.; Mul, M.F.; Reenen, C.G. van. 2011 Simplifying the Welfare Quality assessment protocol for broilers = Vereenvoudiging van het Welfare Quality protocol voor het meten van welzijn bij vleeskuikens. Lelystad: Wageningen UR Livestock Research, (Report / Wageningen UR Livestock Research 533) - 61 pp.

Jong, I.C. de; Gunnink, H.; Hindle, V.A., 2015. Implementation of the Welfare Quality broiler assessment protocol - final report: overview of outcome-based measurement of broiler welfare and a general discussion on the Welfare Quality broiler assessment protocol. Wageningen: Wageningen UR Livestock Research, (Livestock Research report 833) - 57 pp.

Jong, I. C. de, V. A. Hindle, A. Butterworth, B. Engel, P. Ferrari, H. Gunnink, T. P. Moya, F. A. M. Tuyttens, and C. G. van Reenen. 2016. Simplifying the Welfare Quality $((R))$ assessment protocol for broiler chicken welfare. Animal 10:117-127. doi 10.1017/s1751731115001706.

Jong, I.C. de; Gerritzen, Marien; Reimert, H.G.M.; Lohman, T. (2018). Identification of risk factors and prevalence of injuries at different stages of the broiler slaughter process. The XVth European Poultry Conference: Conference Information and Proceedings / Prukner-Radovčić, Estella, Medić, Helga, Zagreb: - p. $240-240$.

Gocsik, E., S. D. Brooshooft, I. C. de Jong, and H. W. Saatkamp. 2016. Cost-efficiency of animal welfare in broiler production systems: A pilot study using the Welfare Quality (R) assessment protocol. Agric. Syst. 146:55-69. doi 10.1016/j.agsy.2016.04.001.

Jacobs, L. 2016. Road to better welfare - Welfare of broiler chickens during transportation. Doctoral thesis. Ghent University.

Jacobs, L., E. Delezie, L. Duchateau, K. Goethals, and F. A. M. Tuyttens. 2017a. Broiler chickens dead on arrival: associated risk factors and welfare indicators. Poultry Science 96:259-265. doi 10.3382/ps/pew353.

Jacobs, L., E. Delezie, L. Duchateau, K. Goethals, and F. A. M. Tuyttens. 2017b. Impact of the separate pre-slaughter stages on broiler chicken welfare. Poultry Science 96:266-273. doi $10.3382 /$ ps/pew361.

Jacobs, L., E. Delezie, L. Duchateau, K. Goethals, D. Vermeulen, J. Buyse, and F. A. M. Tuyttens. 2017c. Fit for transport? Broiler chicken fitness assessment for transportation to slaughter. Anim. Welf. 26:335-343. doi 10.7120/09627286.26.3.335. 
Kittelsen, K. E., E. G. Granquist, O. Kolbjornsen, O. Nafstad, and R. O. Moe. 2015a. A comparison of post-mortem findings in broilers dead-on-farm and broilers dead-on-arrival at the abattoir. Poultry Science 94:2622-2629. doi 10.3382/ps/pev294.

Kittelsen, K. E., E. G. Granquist, G. Vasdal, E. Tolo, and R. O. Moe. 2015b. Effects of catching and transportation versus pre-slaughter handling at the abattoir on the prevalence of wing fractures in broilers. Anim. Welf. 24:387-389. doi 10.7120/09627286.24.4.387.

Kittelsen, K. E., R. O. Moe, K. Hoel, O. Kolbjornsen, O. Nafstad, and E. G. Granquist. 2017.

Comparison of flock characteristics, journey duration and pathology between flocks with a normal and a high percentage of broilers 'dead-on-arrival' at abattoirs. Animal 11:2301-2308. doi $10.1017 / \mathrm{s} 1751731117001161$.

Knierim, U., Gocke, A., 2003. Effect of catching broilers by hand or machine on rates of injuries and dead-on-arrivals. Anim. Welfare 12:63-73.

Knowles, T. G., P. D. Warriss, S. N. Brown, J. E. Edwards, and M. A. Mitchell. 1995. Response of broilers to deprivation of food and water for 24 hours. Br. Vet. J. 151:197-202.

Langkabel, Nina., Maximilian P. O. Baumann, Annika Feiler, Arsooth Sanguankiat, Reinhard Fries; Influence of two catching methods on the occurrence of lesions in broilers. Poult Sci 2015; 94 (8): 1735-1741. doi: 10.3382/ps/pev164.

Lyon, C.E., Papa, C.M., and R. L. Wilson. 1991. Effect of feed withdrawal on yields, muscle pH, and texture of broiler breast meat. Poult. Sci. 70:1020-1025.

Nijdam, E., P. Arens, E. Lambooij, E. Decuypere, and J. A. Stegeman. 2004. Factors influencing bruises and mortality of broilers during catching, transport, and lairage. Poult. Sci. 83(9):1610-1615.

Nijdam, E., Delezie, E., Lambooij, E., Nabuurs, M.J., Decuypere, E., Stegeman, J.A., 2005b. Feed withdrawal of broilers before transport changes plasma hormone and metabolite concentrations. Poult. Sci. 84:1146-1152.

Nijdam, E., A. R. Zailan, J. H. van Eck, E. Decuypere, and J. A. Stegeman. 2006. Pathological features in dead on arrival broilers with special reference to heart disorders. Poult. Sci. 85:1303-1308.

Musilová A., Kadlčáková V., Lichovníková M. 2013. The effect of broiler catching method on quality of carcasses. Mendelnet 2/2013.

Mitchell, M.A. and P.J. Kettlewell, 2009. Welfare of poultry during transport - a review. Poultry Welfare Symposium Cervia, Italy, 18-22 May 2009.

Petracci, M., Bianchi, M and Cavani, C. Pre-slaughter factors affecting mortality, live weight loss, and carcass quality in broiler chickens. XVII th European Symposium on the Quality of Poultry Meat. The Netherlands, 23-26 May 2005.

Rijksoverheid.nl: https://www.nvwa.nl/onderwerpen/dierenwelzijn/documenten/export/veterinair/ksdocumenten/werkvoorschriften-dierwelzijn/wlzvl-030-toezicht-op-welzijn-pluimvee-konijnenslachthuizen.

Vecerek, V., S. Grbalova, E. Voslarova, B. Janackova, and M. Malena, 2006. Effects of Travel Distance and the Season of the Year on Death Rates of Broilers Transported to Poultry Processing Plants. Poultry Science 85:1881-1884. 
Voslářová E., B. Janáčková, L. Rubešová, A. Kozák, I. Bedáňová, L. Steinhauser,

V. Večerek: Mortality Rates in Poultry Species and Categories during Transport for Slaughter. Acta Vet. Brno 2007, 76: S101-S108.

Welfare Quality. 2009. The Welfare Quality Assessment Protocol for Broiler Chickens and Laying Hens. The Welfare Quality Consortium, Lelystad. 
Bijlage 1 Scoreformulieren vang- en laadletsel 


\section{In wachtruimte:}

Datum:

Tijd:

slachterij:

Koppel:

panting

Waarnemer:

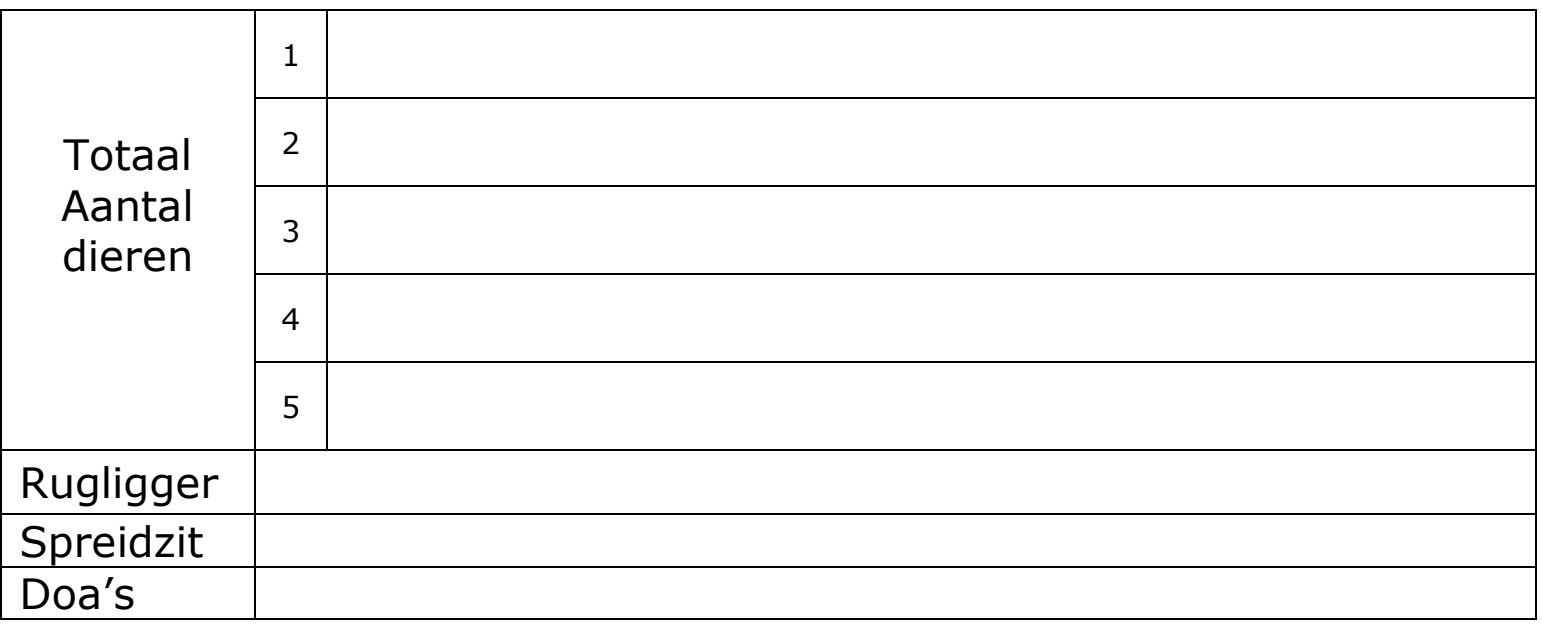

Bloedingen: Noteer rood/blauw

\begin{tabular}{|c|c|c|c|c|}
\hline \multicolumn{2}{|l|}{ aantal } & \multirow[t]{2}{*}{ Klein $<0.5 \mathrm{~cm}$} & \multirow[t]{2}{*}{ Middel $0.5-1 \mathrm{~cm}$} & \multirow[t]{2}{*}{$\begin{array}{l}\text { Groter dan } 1 \\
\mathrm{~cm}\end{array}$} \\
\hline \multirow{5}{*}{ borst } & 1 & & & \\
\hline & 2 & & & \\
\hline & 3 & & & \\
\hline & 4 & & & \\
\hline & 5 & & & \\
\hline \multirow{5}{*}{ vleugel } & 1 & & & \\
\hline & 2 & & & \\
\hline & 3 & & & \\
\hline & 4 & & & \\
\hline & 5 & & & \\
\hline \multirow{5}{*}{ Poot } & 1 & & & \\
\hline & 2 & & & \\
\hline & 3 & & & \\
\hline & 4 & & & \\
\hline & 5 & & & \\
\hline \multicolumn{5}{|c|}{ Dislocatie vleugel } \\
\hline \multicolumn{5}{|c|}{ Breuk vleugel } \\
\hline \multicolumn{5}{|c|}{ Dislocatie poot } \\
\hline \multicolumn{5}{|c|}{ Breuk poot } \\
\hline \multicolumn{2}{|c|}{ Huidbeschadiging } & & & \\
\hline Opmerk & & & & \\
\hline
\end{tabular}




\section{In slachterij:}

Datum:

Tijd:

slachterij:

Koppel:

waarnemer:

Vleugelbreuk en dislocatie:

\begin{tabular}{|c|c|c|}
\hline Bpen & Breuken & dislocatie \\
\hline open & & \\
\hline gesloten & & \\
\hline & & \\
& & \\
& & \\
& & \\
\end{tabular}




\section{In slachterij:}

Datum:

Tijd:

slachterij:

Koppel:

waarnemer:

Vleugel bloedingen:

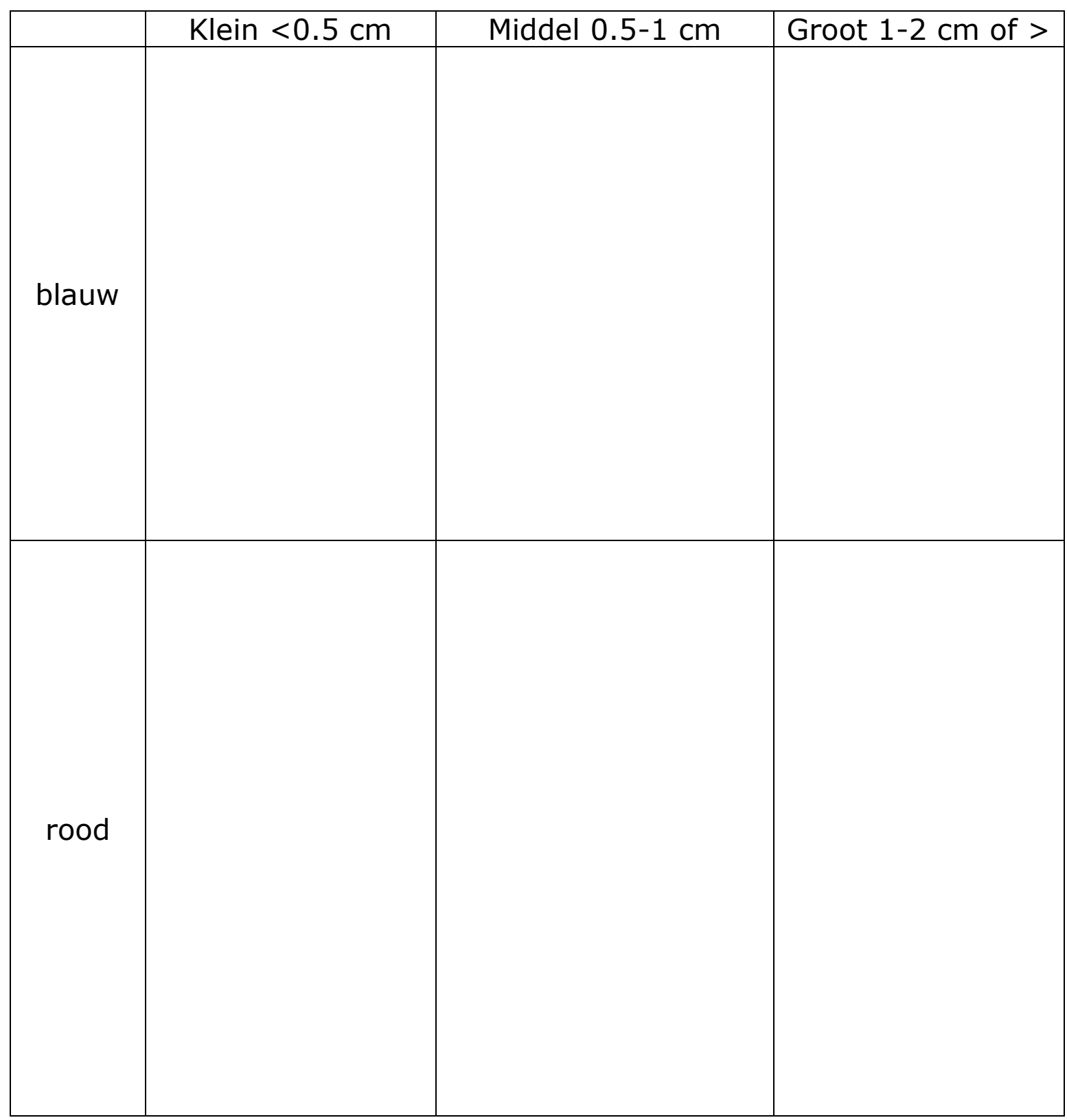




\section{In slachterij:}

Datum:

Tijd:

slachterij:

Koppel:

waarnemer:

Borst bloedingen:

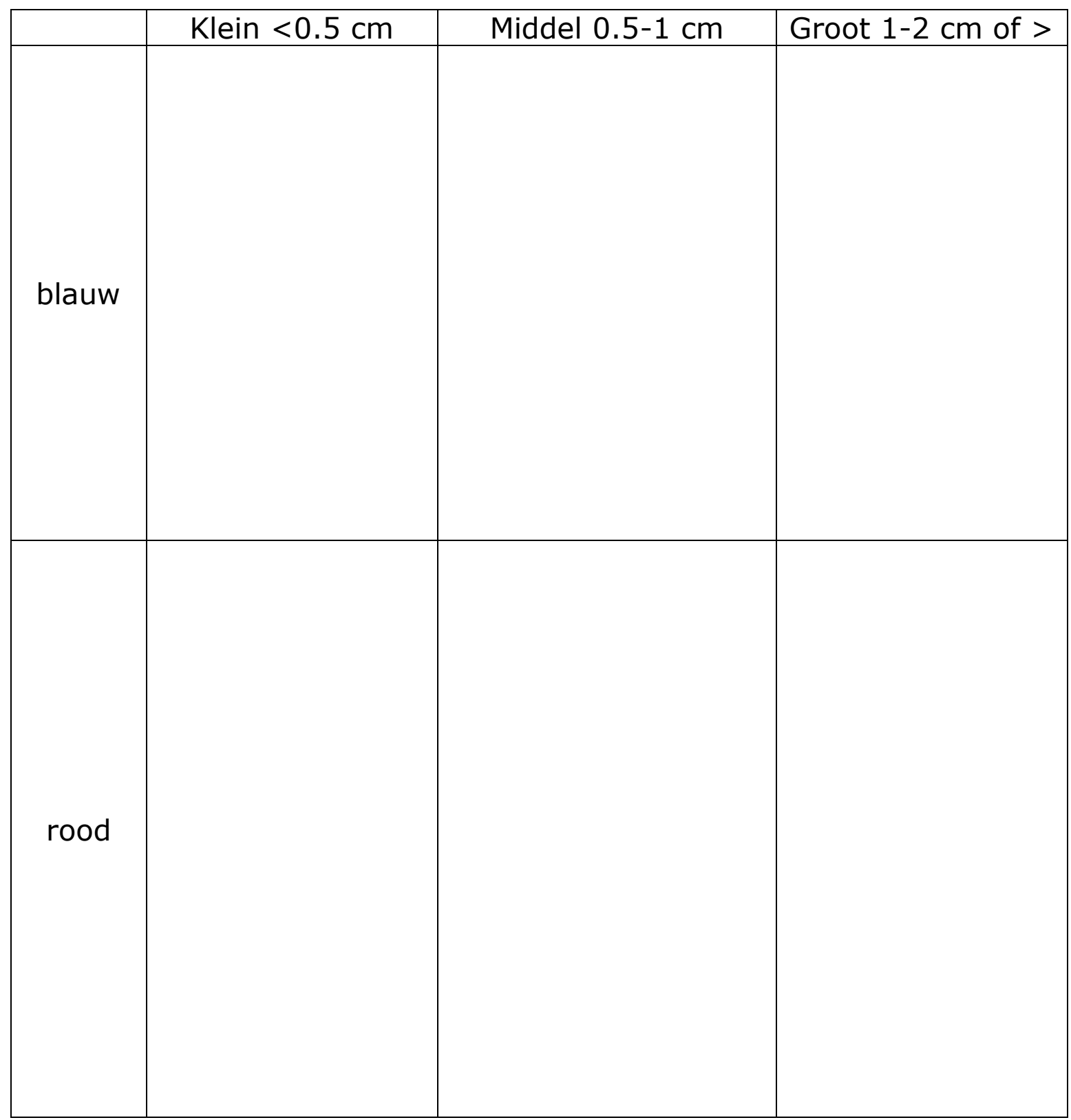




\section{In slachterij:}

Datum:

Tijd:

slachterij:

Koppel:

waarnemer:

Poot bloedingen:

\begin{tabular}{|c|c|c|c|}
\hline \multirow{3}{*}{ blauw } & Klein $<0.5 \mathrm{~cm}$ & Middel $0.5-1 \mathrm{~cm}$ & Groot $1-2 \mathrm{~cm}$ of $>$ \\
\hline & & & \\
rood & & & \\
& & & \\
\hline
\end{tabular}

Poot breuk en dislocatie:

\begin{tabular}{|c|c|c|}
\hline open & Breuken & dislocatie \\
\hline gesloten & & \\
\hline & & \\
\hline
\end{tabular}




\section{Algemeen:}

Datum:

Slachterij:

Koppel:

Gezondheids documenten:

Tijdstip vangen:

Tijdsduur vangen:

Beladingsgraad:

Type container en staat:

Transporttijd:

Wachttijd slachterij:

Ras:

Leeftijd:

Gemiddeld gewicht:

$\%$ afkeuringen

\% DOA

Vang methode: 


\section{Bijlage 2 Voorbeeld rapportjes terugkoppeling koppelbeoordelingen}

\begin{tabular}{|c|c|c|c|}
\hline \multirow{3}{*}{$\begin{array}{l}\text { Resultaten welzijnsmonitor } \\
\text { vleeskuikens } \\
\text { Bedrijf: } \\
\text { Stal: } \\
\text { Datum bezoek: } \\
\text { Datum slacht: }\end{array}$} & & \multicolumn{2}{|c|}{$\begin{array}{l}\text { Concepten met trager } \\
\text { groeiende } \\
\text { vleeskuikenrassen }\end{array}$} \\
\hline & & \multicolumn{2}{|c|}{\begin{tabular}{|l|}
$\begin{array}{l}\text { Grenzen obv } 25 \% \text { en } \\
75 \% \text { percentiel* }\end{array}$ \\
\end{tabular}} \\
\hline & Uw waarde & $\leq 25 \%$ & $\geq 75 \%$ \\
\hline $\begin{array}{l}\% \text { vleeskuikens met gait score } \geq 3 \text { (kan zich moeilijk tot niet } \\
\text { voortbewegen) }\end{array}$ & 12.67 & $\leq 0.6$ & $\geq 7.1$ \\
\hline Voetzoollaesiescore (0-200) & 3.70 & $\leq 1.12$ & $\geq 22.9$ \\
\hline Hakdermatitis, \% kuikens met ernstige & 0.00 & 0 & $\geq 1$ \\
\hline Bevuiling, \% kuikens met matig tot ernstige & 10.28 & $\leq 3.6$ & $\geq 32$ \\
\hline Borstirritatie, \% kuikens met matig tot ernstige & 0.93 & 0 & $\geq 1.9$ \\
\hline Krassen en verwondingen, $\%$ kuikens met & 11.21 & 0 & $\geq 0.91$ \\
\hline Uitval \% (tot en met moment van bezoek) & 2.43 & $\leq 1.11$ & $\geq 2$ \\
\hline Strooselkwaliteit (op een schaal van 0-4) & 2.00 & $\leq 1.14$ & $\geq 1.9$ \\
\hline \% kuikens dat hijgt (te hoge omgevings temp.) & 0.00 & 0 & $\geq 1$ \\
\hline Dead-on-arrival \% & 0.01 & $\leq 0.022$ & $\geq 0.07$ \\
\hline Afkeur\% aan de slachtlijn & 0.20 & $\leq 0.27$ & $\geq 0.54$ \\
\hline
\end{tabular}


Overige verwondingen (breuk, kneuzing) waargenomen

ja/nee?

Vermagerde kuikens, \%

Gedrag:

Wordt stofbaden waargenomen ja/nee?

Wordt scharrelen waargenomen ja/nee?

Wordt poetsgedrag waargenomen ja/nee?

nee

Bij aanwezigheid verrijking, wordt deze gebruikt

ja/nee?

ja

Bij aanwezigheid uitloop, wordt deze gebruikt

ja/nee?

n.v.t.

* grenzen $25 \%$ en $75 \%$ percentiel (beste koppels en slechtste koppels voor een bepaald kenmerk) bepaald o.b.v. gegevens verzameld in 2013/2014 bij concepten met trager groeiende vleeskuikens (gegevens van 47 koppels) 


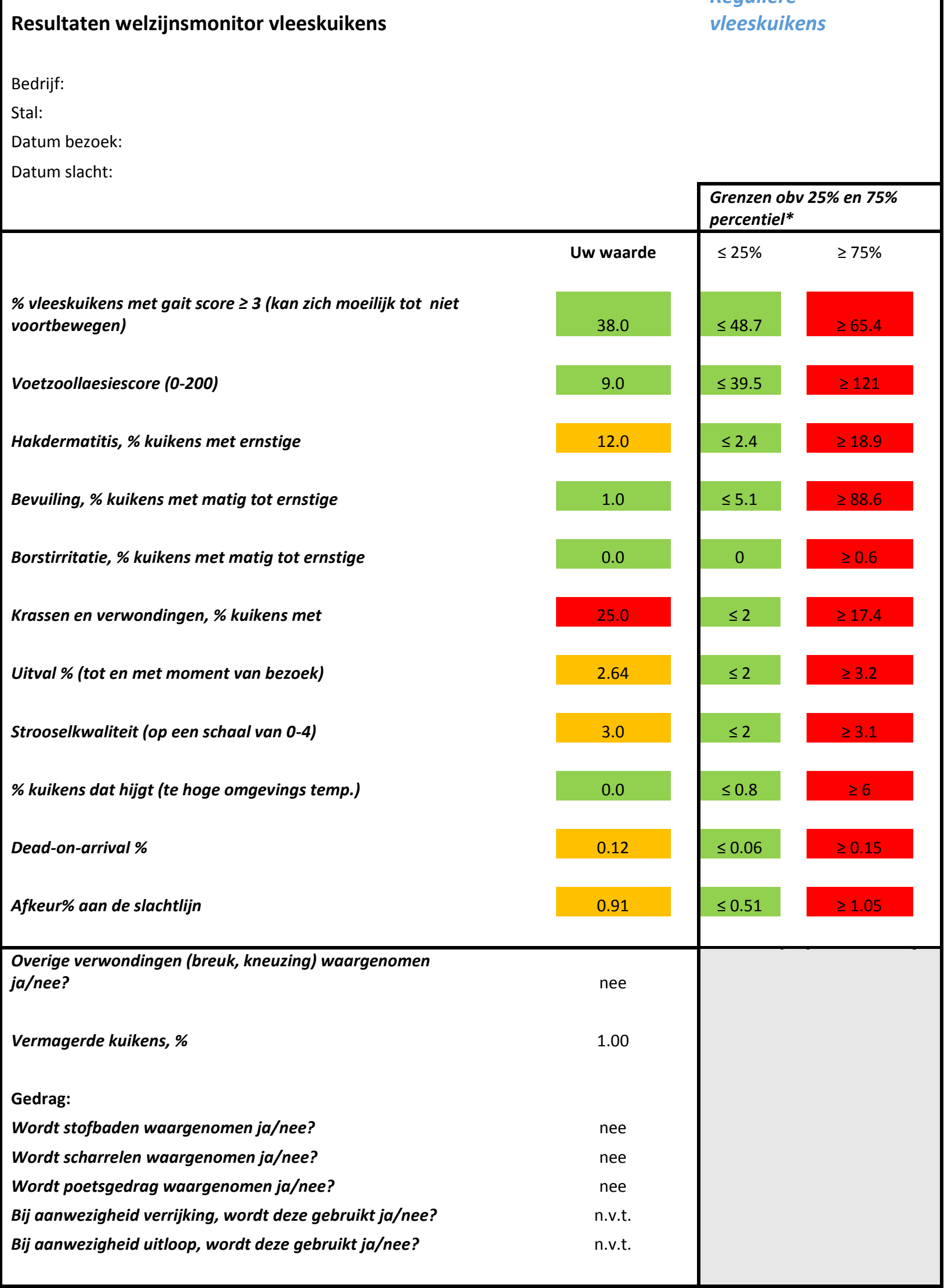

* grenzen $25 \%$ en $75 \%$ percentiel (beste koppels en slechtste koppels voor een bepaald kenmerk)

bepaald o.b.v. gegevens verzameld in 2013/2014 bij koppels reguliere vleeskuikens (gegevens van 147 koppels) 


\section{Bijlage 3 Overzicht resultaten subset koppels}

Tabel 3.1: Gemiddelden en standaarddeviatie voor een aantal kenmerken gemeten met behulp van de welzijnsmonitor, voor de subset van reguliere en trager groeiende koppels.

\begin{tabular}{lcc}
\hline & Regulier & Trager groeiend \\
\hline & Gemiddeld \% ( \pm SD) & Gemiddeld \% ( \pm SD) \\
Mortaliteit (dood+selectie) & $3.73( \pm 0.89)$ & $1.90( \pm 0.43)$ \\
Vermagerde kuikens & $0.32( \pm 0.49)$ & $1.57( \pm 2.25)$ \\
Kuikens hijgen & $0.20( \pm 0.44)$ & $0.08( \pm 0.24)$ \\
Kuikens huddlen & $12.13( \pm 14.63)$ & $0.73( \pm 1.51)$ \\
Strooiselscore & $2.44( \pm 0.55)$ & $1.38( \pm 0.51)$ \\
Stofscore & $0.61( \pm 0.77)$ & $0.63( \pm 0.81)$ \\
& & \\
Antibioticagebruik & Aantal koppels & Aantal koppels \\
Stofbaden & 1 & 0 \\
Scharrelen & 1 & 2 \\
Poetsen & 2 & 5 \\
\hline
\end{tabular}

Tabel 3.2. Gemiddelde en standaarddeviatie voor enkele slachtkenmerken in de subset van koppels gemeten met de welzijnsmonitor.

\begin{tabular}{lcc}
\hline & Regulier & Trager groeiend \\
\hline DOA & Gemiddeld \% ( \pm SD) & Gemiddeld \% ( \pm SD) \\
Afkeur & $0.08( \pm 0.03)$ & $0.02( \pm 0.01)$ \\
& $0.87( \pm 0.35)$ & $0.41( \pm 0.34)$ \\
Aanlever gewicht & Gemiddeld gram ( \pm SD) & Gemiddeld gram ( \pm SD) \\
& $2503( \pm 368)$ & $2434( \pm 110)$ \\
\hline
\end{tabular}

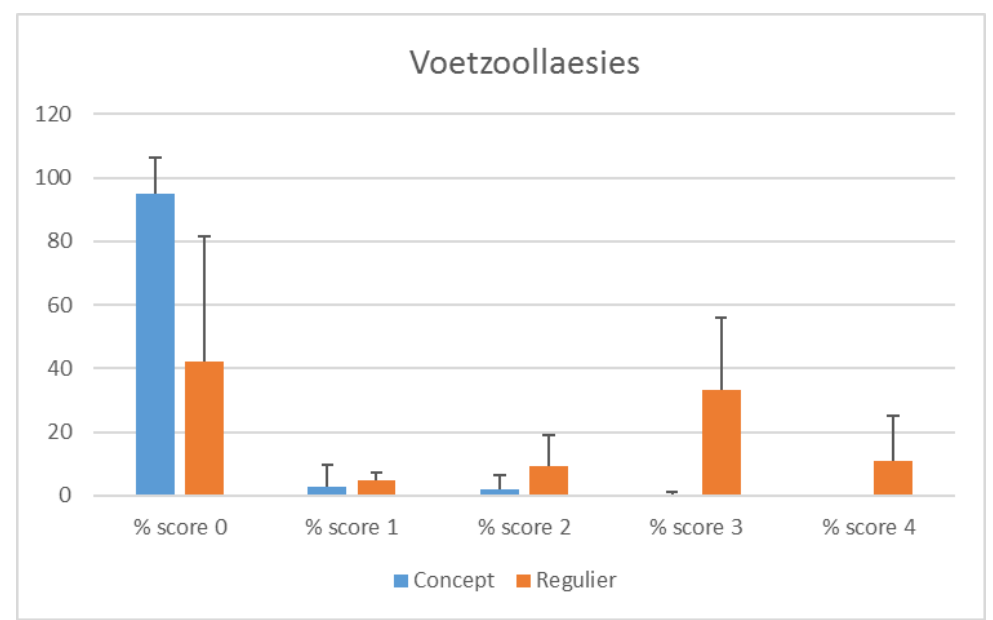

Figuur 3.1. Gemiddeld percentage kuikens per klasse voetzoollaesies voor de subset koppels beoordeeld met de welzijnsmonitor. Een hogere score betekent meer laesies. 


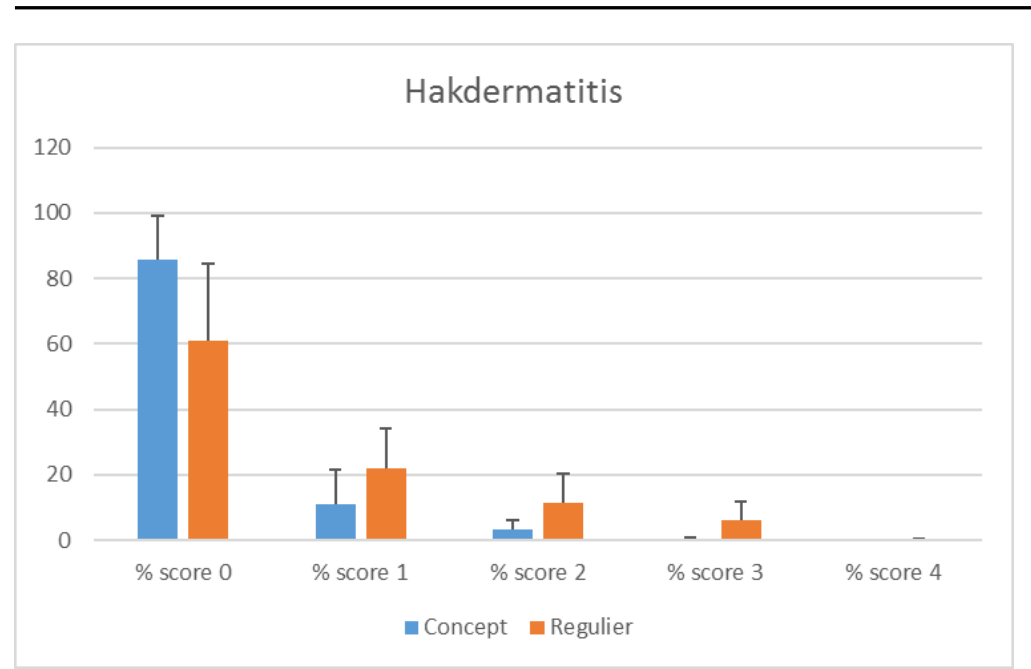

Figuur 3.2. Gemiddeld percentage kuikens per klasse hakdermatitis voor de subset koppels beoordeeld met de welzijnsmonitor. Een hogere score betekent meer hakdermatitis.

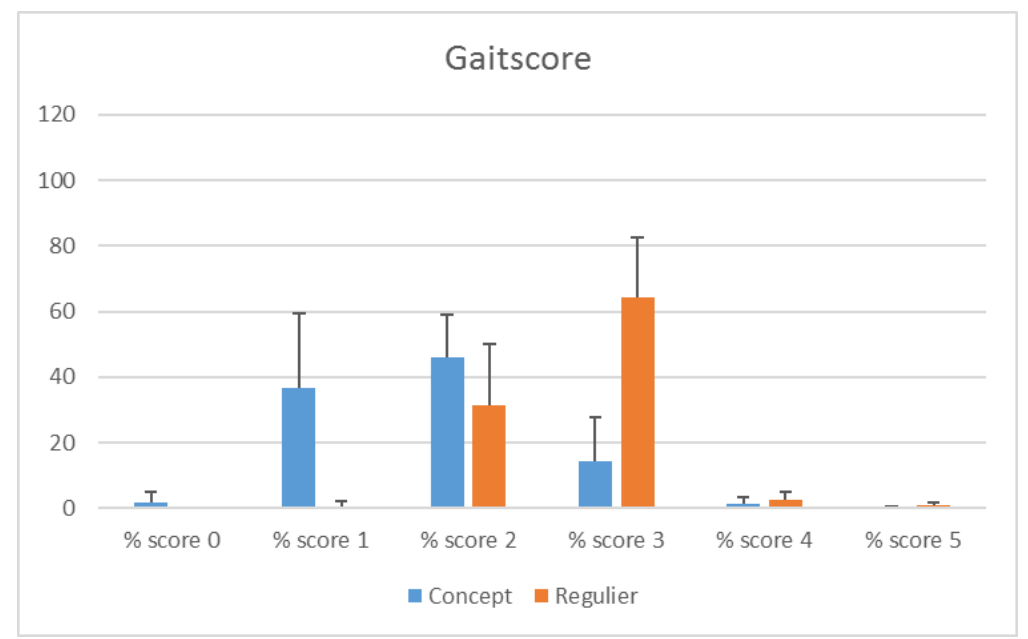

Figuur 3.3. Gemiddeld percentage kuikens per klasse van de gait score voor de subset koppels beoordeeld met de welzijnsmonitor. Een hogere klasse betekent een slechtere locomotie.

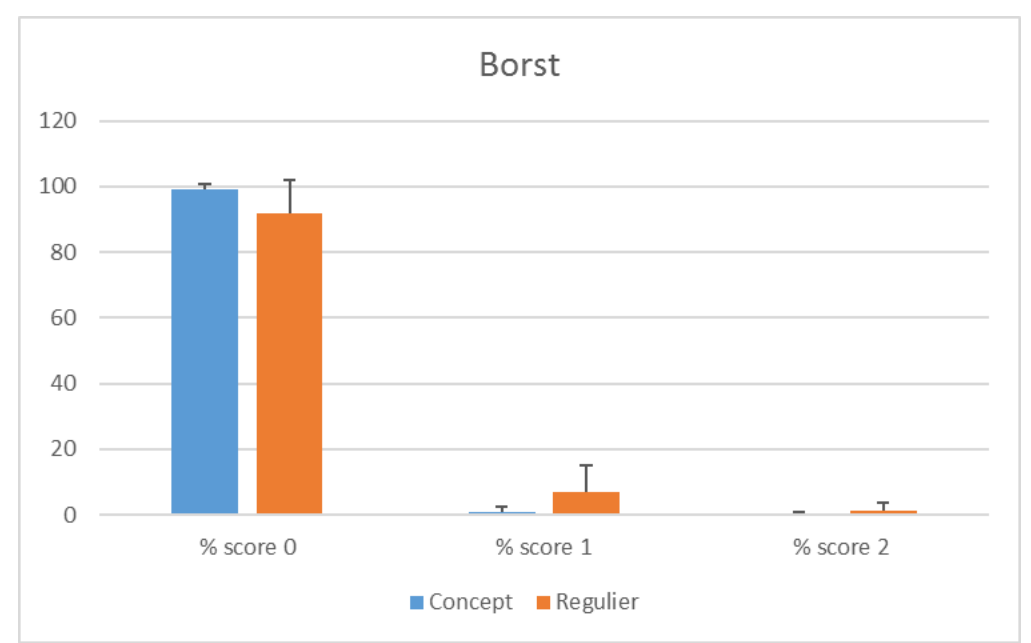

Figuur 3.4. Gemiddeld percentage kuikens met borstirritatie per klasse voor de subset koppels beoordeeld met de welzijnsmonitor. Een hogere klasse betekent meer borstirritatie. 


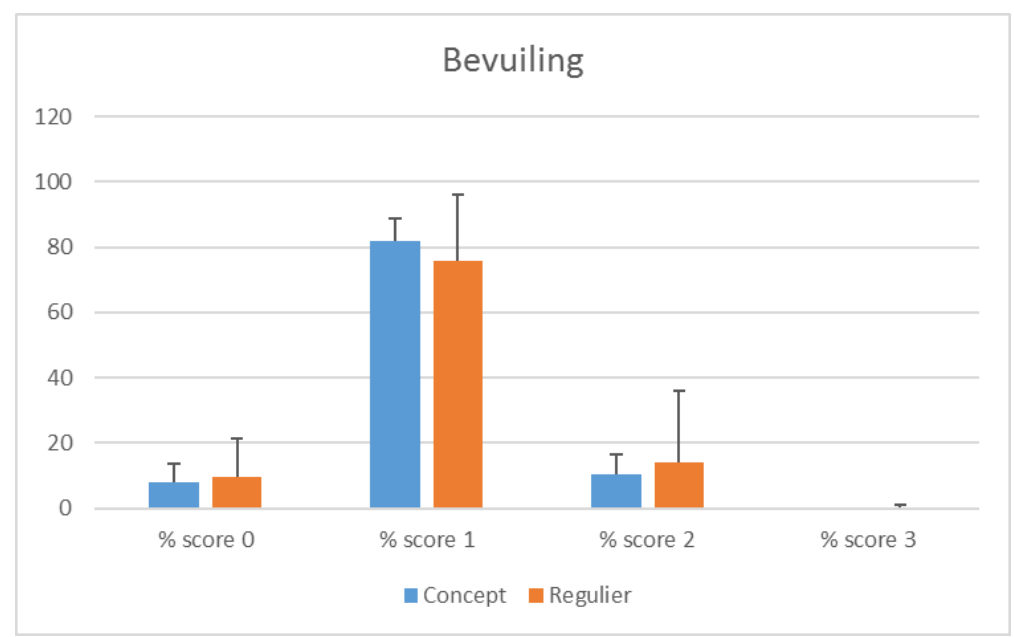

Figuur 3.5. Gemiddeld percentage kuikens per klasse bevuiling voor de subset koppels beoordeeld met de welzijnsmonitor. Een hogere score betekent meer bevuilde kuikens.

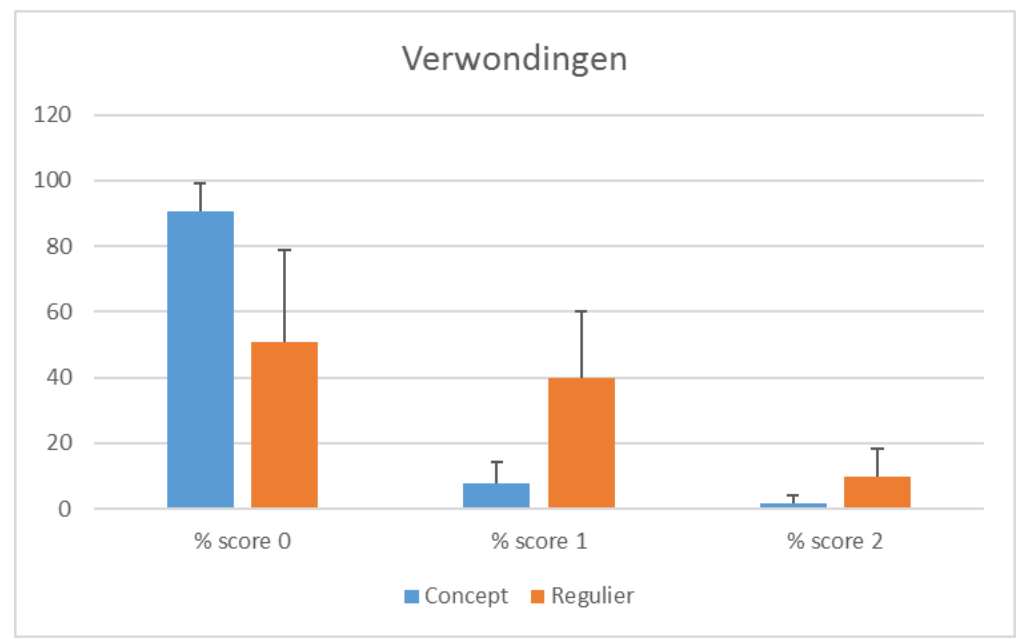

Figuur 3.6. Gemiddeld percentage kuikens per klasse verwondingen voor de subset koppels beoordeeld met de welzijnsmonitor. Een hogere score betekent meer krassen/verwondingen.

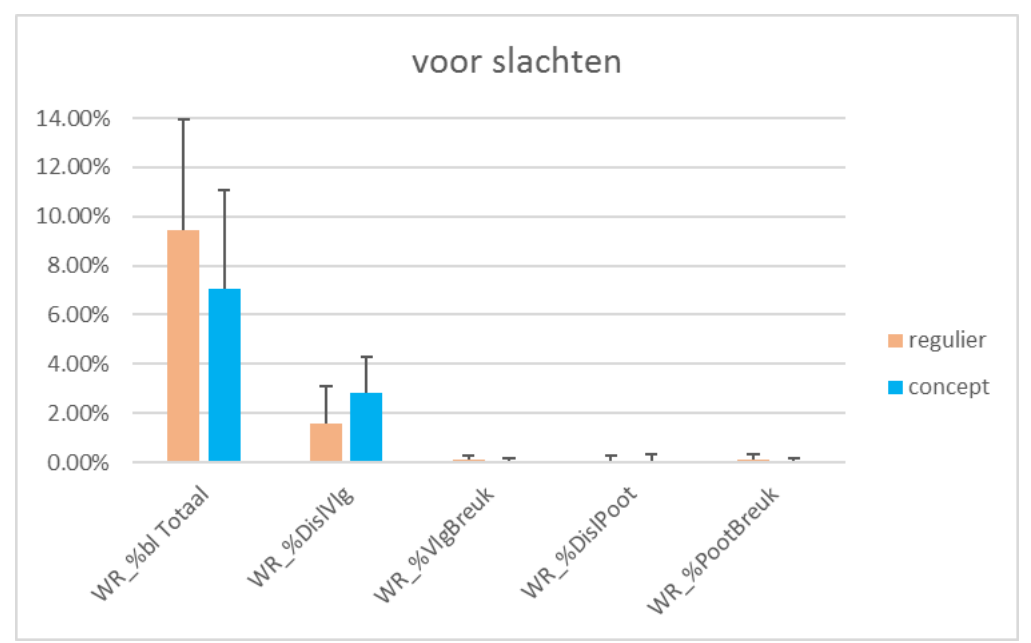

Figuur 3.7. Gemiddeld percentage kuikens met letsel zoals beoordeeld voor slachten de subset van koppels beoordeeld met de welzijnsmonitor. 


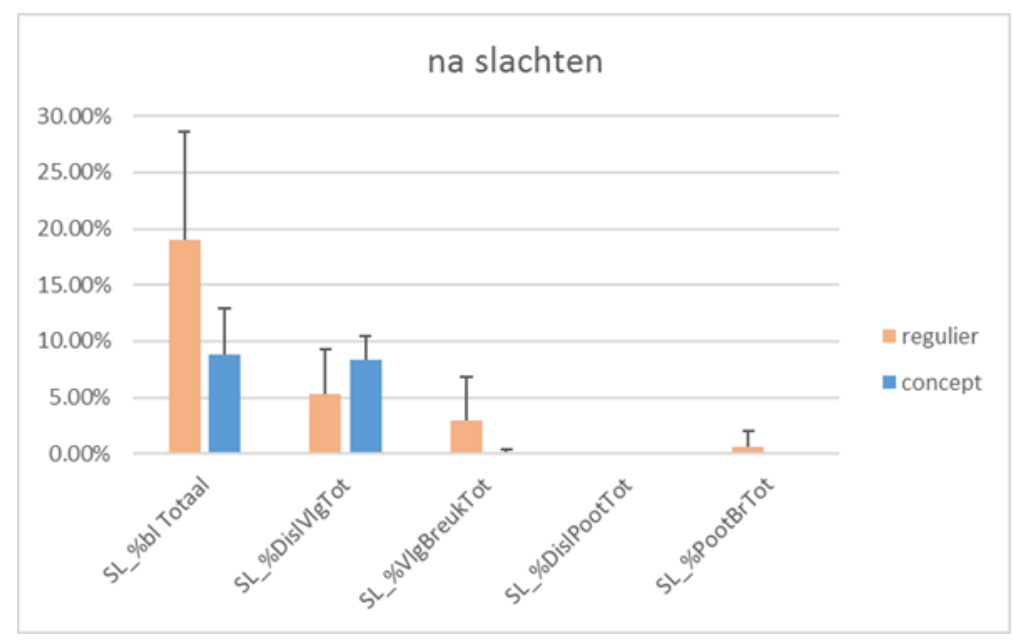

Figuur 3.8. Gemiddeld percentage kuikens met schade na slachten voor de subset van koppels beoordeeld met de welzijnsmonitor. 


\section{Bijlage 4 Figuren relatie voetzoollaesiescore en vang- en laadletsel}
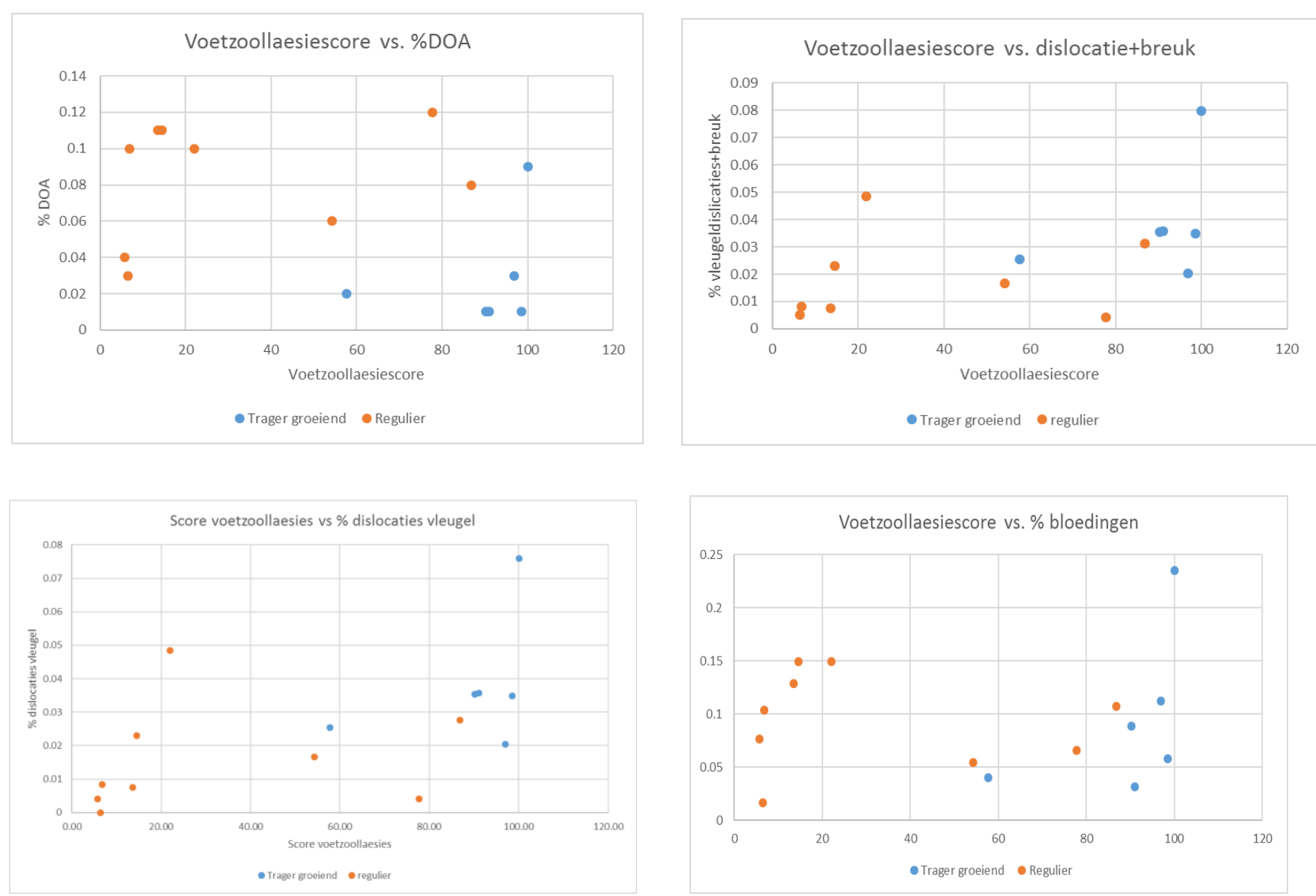


\section{Bijlage 5 Relatie tussen score locomotie en vang- en laadletsel}
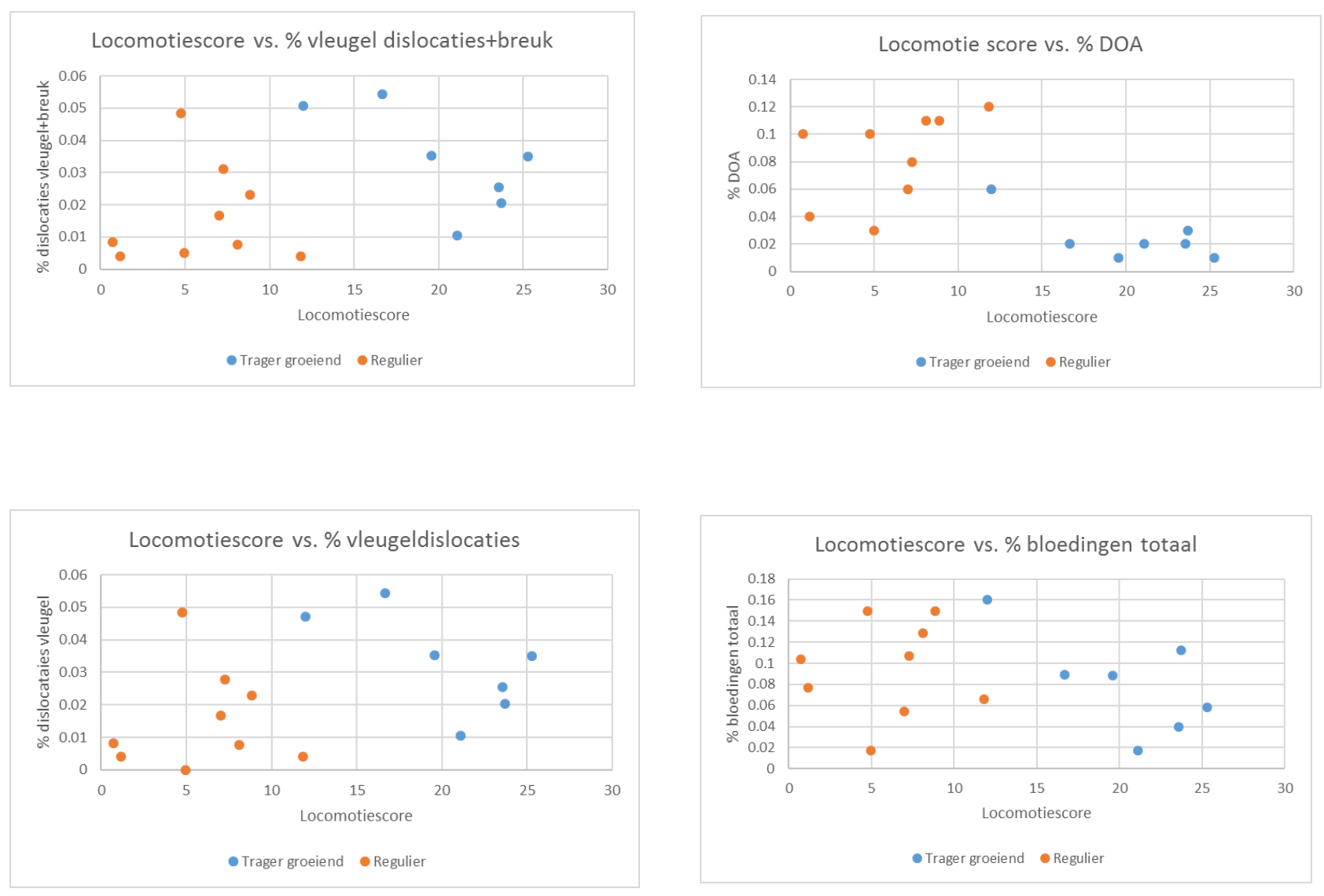


\section{Bijlage 6 Relatie tussen mortaliteitsscore en vang- en laadletsel}
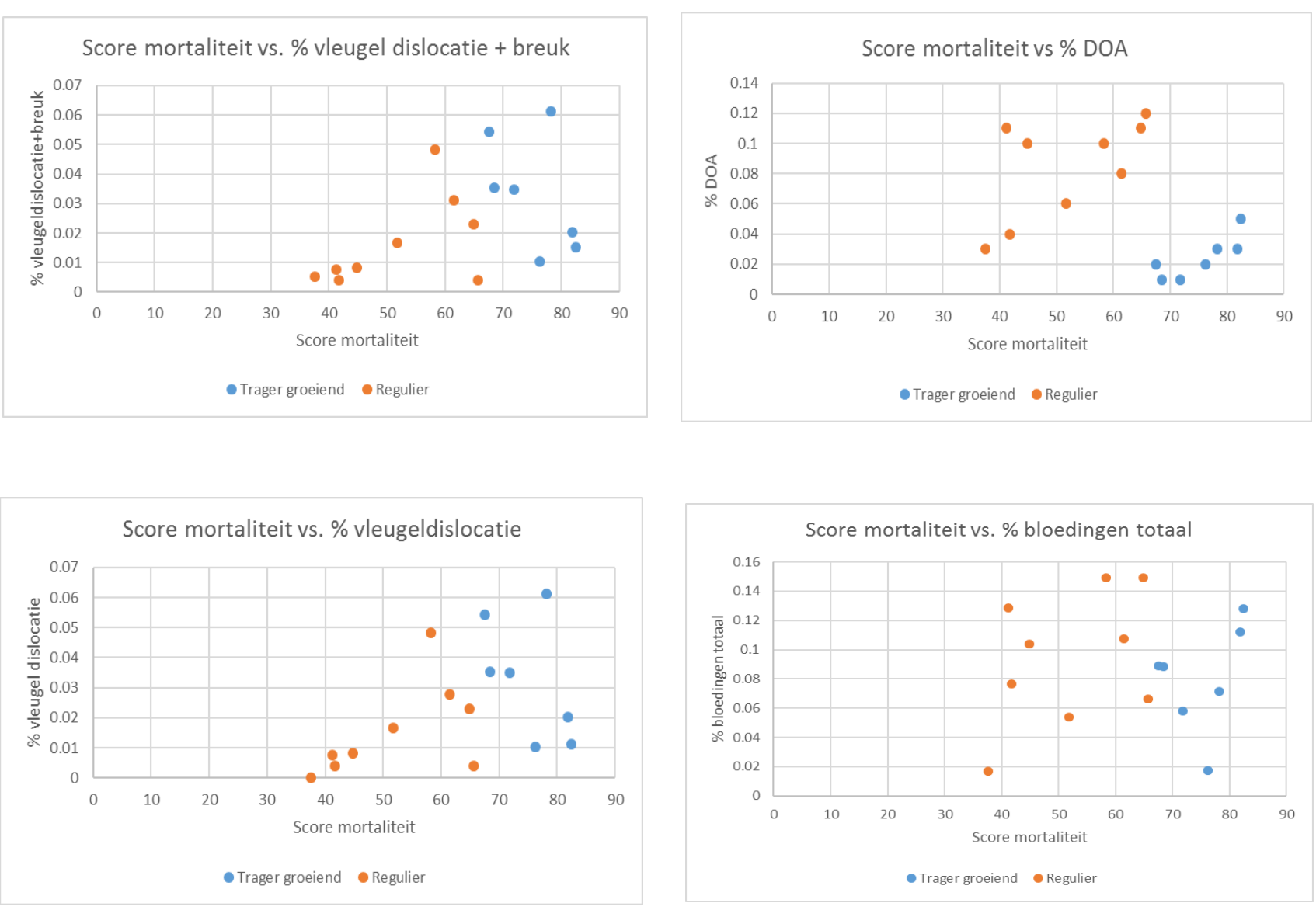


\section{Bijlage 7 Relatie tussen score totaal welzijn en vang- en laadletsel}
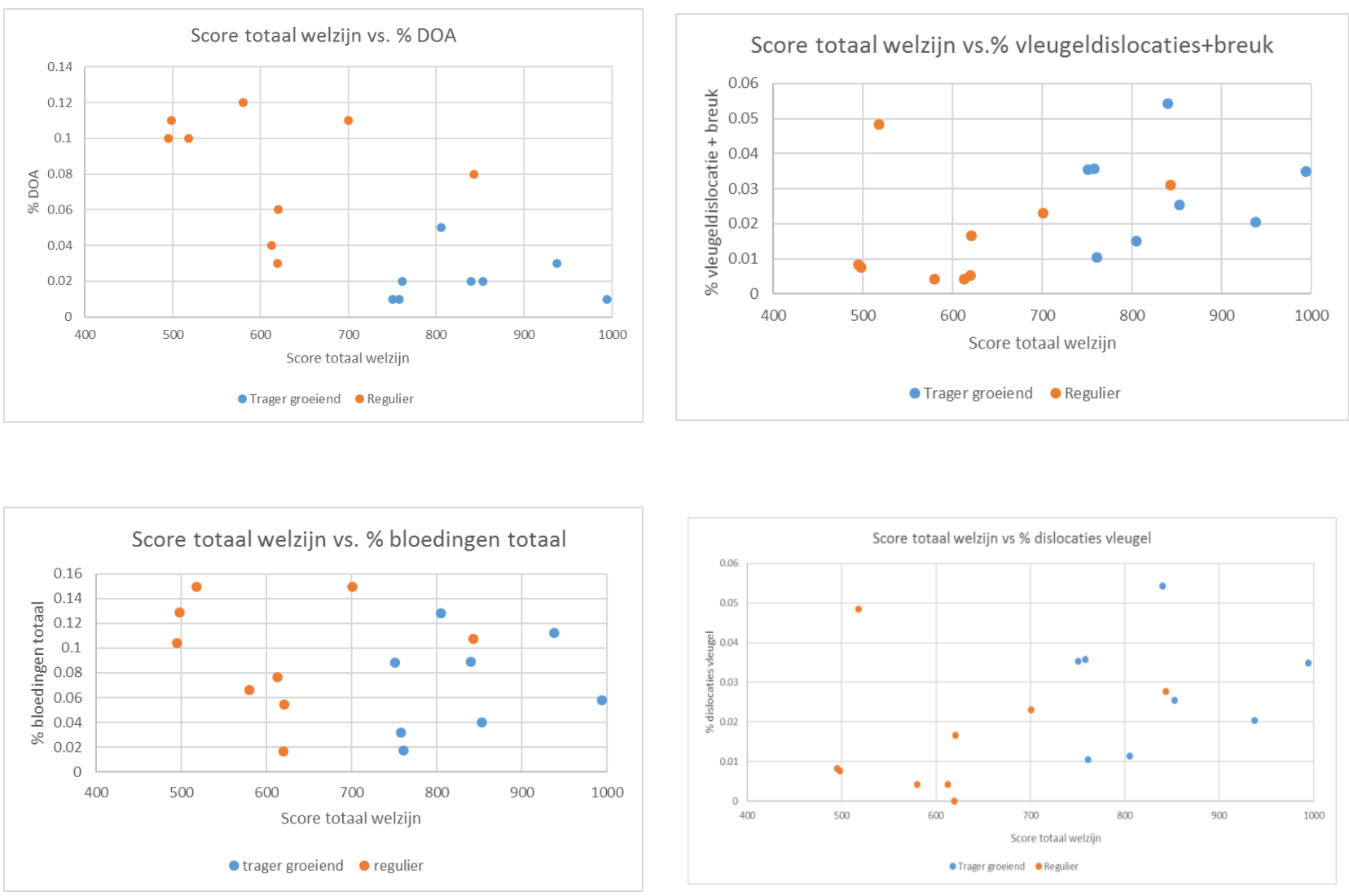


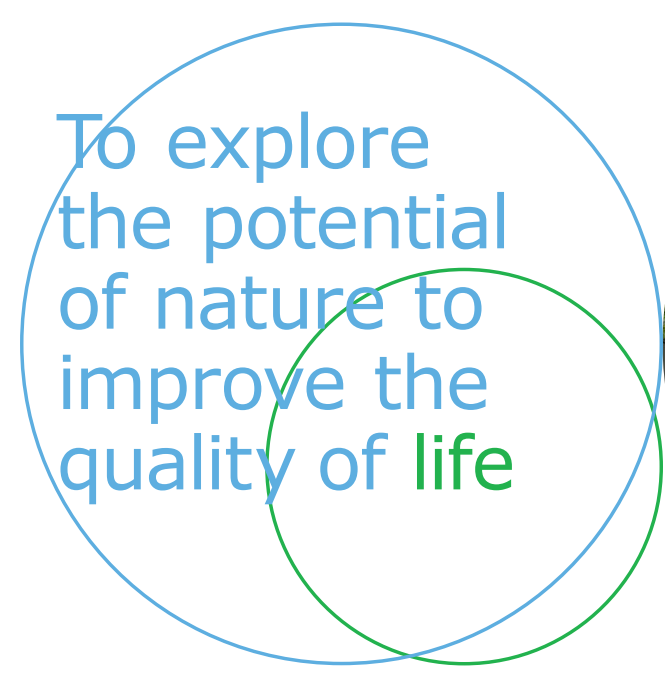

Wageningen Livestock Research Postbus 338 $6700 \mathrm{AH}$ Wageningen

T 0317483953

E info.livestockresearch@wur.nl www.wur.nl/ livestock-research

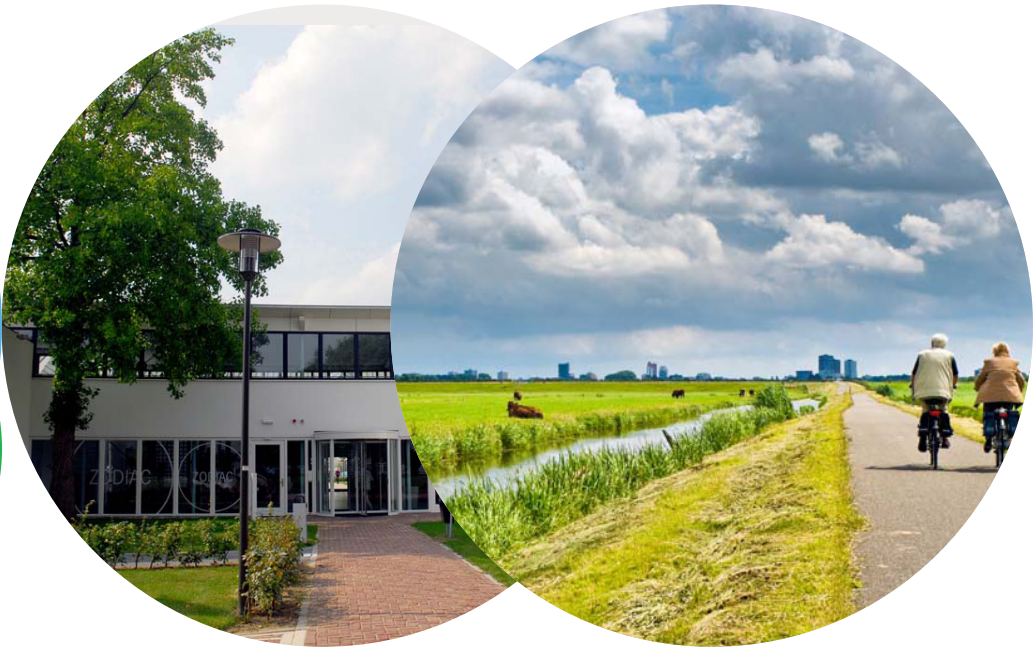

Wageningen Livestock Research ontwikkelt kennis voor een zorgvuldige en renderende veehouderij, vertaalt deze naar praktijkgerichte oplossingen en innovaties, en zorgt voor doorstroming van deze kennis. Onze wetenschappelijke kennis op het gebied van veehouderijsystemen en van voeding, genetica, welzijn en milieu-impact van landbouwhuisdieren integreren we, samen met onze klanten, tot veehouderijconcepten voor de $21 \mathrm{e}$ eeuw.

De missie van Wageningen University \& Research is 'To explore the potential of nature to improve the quality of life'. Binnen Wageningen University \& Research bundelen 9 gespecialiseerde onderzoeksinstituten van Stichting Wageningen Research en Wageningen University hun krachten om bij te dragen aan de oplossing van belangrijke vragen in het domein van gezonde voeding en leefomgeving. Met ongeveer 30 vestigingen, 6.500 medewerkers en 10.000 studenten behoort Wageningen University \& Research wereldwijd tot de aansprekende kennisinstellingen binnen haar domein. De integrale benadering van de vraagstukken en de samenwerking tussen verschillende disciplines vormen het hart van de unieke Wageningen aanpak. 